UNIVERSIDADE DE SÃO PAULO
ESCOLA DE COMUNICAÇÕES E ARTES

CARLOS EDUARDO SOUZA BROCANELLA WITTER

O Ator Musical:

A Musicalidade na composição cênica

SÃO PAULO

2013 


\section{CARLOS EDUARDO SOUZA BROCANELLA WITTER}

\section{O Ator Musical: \\ A Musicalidade na composição cênica}

Dissertação apresentada ao Programa de PósGraduação em Artes Cênicas, da Escola de Comunicações e Artes, da Universidade de São Paulo, como requisito parcial para a obtenção do título de Mestre em Artes Cênicas.

Orientador: Prof. Dr. José Batista Dal Farra Martins.

São Paulo

2013 
Autorizo a reprodução e divulgação total ou parcial deste trabalho, por qualquer meio convencional ou eletrônico, para fins de estudo e pesquisa, desde que citada a fonte.

Catalogação na Publicação Serviço de Biblioteca e Documentação

Escola de Comunicações e Artes da Universidade de São Paulo Dados fornecidos pelo(a) autor(a)

Witter, Carlos Eduardo Souza Brocanella

O Ator Musical: A Musicalidade na composição cênica /

Carlos Eduardo Souza Brocanella Witter. -- São Paulo: C.

S. B. Witter, 2013.

$201 \mathrm{p}$.

Dissertação (Mestrado) - Programa de Pós-Graduação em Artes Cênicas - Escola de Comunicações e Artes / Universidade de São Paulo.

Orientador: José Batista Dal Farra Martins

Bibliografia

1. Formação do Ator 2. Musicalidade cênica 3. Teatro Musical I. Martins, José Batista Dal Farra II. Título. 
Nome: WITTER, Carlos Eduardo Souza Brocanella.

Título: O Ator Musical: A Musicalidade na composição cênica

Dissertação apresentada ao Programa de PósGraduação em Artes, da Escola de Comunicações e Artes da Universidade de São Paulo, como requisito parcial para a obtenção do título de Mestre em Artes Cênicas.

Aprovado em:

Banca Examinadora

Prof. Dr. Instituição:

Julgamento: Assinatura:

Prof. Dr. Instituição:

Julgamento: Assinatura:

Prof. Dr. Instituição:

Julgamento: Assinatura: 


\section{AGRADECIMENTOS}

À minha orientadora, mestra, parceira e madrinha de tantos desejos realizados, Yedda Riberá (in memoriam), por ter acreditado em meu projeto de pesquisa e dividido tantos saberes e experiências, deixando os melhores rastros desse meu percurso e muita saudade.

Ao Zebba, por aceitar me orientar e, mesmo diante de todas as dificuldades que os fatos e eu mesmo impusemos, contribuir com sua parceria e apontamentos incisivos e pertinentes.

Ao Luiz Rodrigues, toda minha gratidão e carinho, por ter incentivado essa jornada, desde o início, e ser um parceiro tão importante e especial, estando sempre ao meu lado. Sua intervenção, por vezes carinhosa e outras vezes dura, me ajudou a caminhar em meu propósito. Sua contribuição enquanto ator-pesquisador foi fundamental para a investigação. E sua dedicação, alimentou-me de força.

À Erika Riedel pela generosidade em rever e apontar carinhosamente cada falha minha nesta escrita.

À Zuca Zenker, Edna Gomes e Camilo Di Giorgi, pela amizade e prontidão em ajudar-me na etapa final desta pesquisa.

À Leticia Chiocheta, Lívia Figueira, Nathaly Matsuda pela amizade, apoio e contribuição prática nas experiências sobre musicalidade. Especialmente, grato!

Á Pietra, minha filha, por ser compreensiva e por me alimentar de amor a todo instante.

Ao Ivam Cabral, por possibilitar indiretamente que esse trabalho chegasse até aqui e ser um amigo querido em todas as horas. 
Ao Joaquim Gama, pela amizade, carinho e preciosas dicas na escrita desse trabalho.

Ao Fábio Cintra pelas generosas contribuições, conversas e orientações de cantina.

Ao professor Armando Sérgio da Silva, a partir de quem iniciei minhas atividades de pesquisador no CAC, por intermédio do CEPECA.

Às professoras Maria Thais e Ingrid Koudela, com quem dividi angústias e saberes e que me forneceram bases sólidas para a escrita dessa dissertação.

À professora Beth Lopes pelas importantes pontuações na qualificação e pelo carinho sempre que nos encontramos.

Aos alunos da graduação do CAC/ECA/USP e da SP Escola de Teatro, por possibilitarem um aprofundamento em diversos níveis das investigações aqui descritas.

Aos professores e colegas do CAC/ECA/USP, pela imensa contribuição em meu aprendizado e por colaborarem com meu amadurecimento acadêmico e pessoal.

À minha mãe e irmãos, que de longe sempre acreditaram nesse trabalho. 
Yedda,

Ter alguém como mestre é algo indescritivelmente bom. Aprender sobre a vida, é aprender sobre a arte e sobre si. Muito além de Meyerhold, Teatro Oriental, William James, Damásio e étude, esta é a experiência. E ela não é passível de ser descrita num trabalho científico. Não tenho como agradecê-la, restame apenas tentar honrar tudo que pudemos compartilhar nesses poucos, mas incríveis anos em que me deu a honra de ser seu aprendiz!

Com muito amor e respeito, obrigado... Sempre... 



\section{RESUMO}

WITTER, Carlos Eduardo Souza Brocanella. O Ator Musical: A Musicalidade na composição cênica. 2013. 201f. Dissertação (Mestrado). Escola de Comunicações e Artes, Universidade de São Paulo, 2013.

Esta pesquisa teórico-prática realiza um estudo do pensamento e dos princípios de trabalho de Vsévolod Meyerhold a partir da musicalidade no trabalho do ator, utilizando princípios de Murray Schafer e Dalcroze, para a compreensão da musicalidade no corpo do ator e no espaço cênico, com vistas à uma formação mais global do ator. Neste sentido buscamos traçar princípios pedagógicos e fundamentos artísticos sobre os quais investigamos teórica e praticamente. Sua contribuição pode ser útil para que 0 ator vislumbre possibilidades de trabalho exploratório sobre si mesmo, passando por um processo de incorporação da musicalidade enquanto elemento constitutivo de sua prática e organizador do tempo no espaço. Traça ainda breves comentários sobre um teatro múltiplo, no qual dialoguem todas as linguagens artísticas de maneira não disjuntiva. Busca, finalmente, uma formação integral do ator enquanto humano e enquanto artista.

Palavras-chave: Teatro. Música. Musicalidade. Teatro Musical. Meyerhold. Multiplicidade. Pedagogia Teatral. Formação do ator. 


\begin{abstract}
WITTER, Carlos Eduardo Souza Brocanella. The Musical Actor: The Musicality at the Scenic Composition. 201f. Dissertação (Mestrado). Escola de Comunicações e Artes, Universidade de São Paulo, 2013.

This research makes a theoretical and practical study of thinking and working principles of Vsévolod Meyerhold from the musicality at the actor's work using Murray Schafer's and Dalcroze's principles for the understanding of the musicality in actor's body and at the scenic space, looking for a global training of the actor. In this sense, we try to describe pedagogical principles and artistic elements on wich we study theoretical and practically. Its contribution can be useful for the envision possibilities of the actors on their exploratory work, through himself, passing through a process of incorporation of the musicality while constitutive element of their practice and a time organizer at the space. It also makes short comments about a plural theater in wich all the artistic languages can dialogue in a non-disjunctive way. Finally, it tries to find an integrate training of the actor as human and as an artist.
\end{abstract}

Keywords: Theatre. Music. Musicality. Musical Theater. Meyerhold. Multiplicity. Theater Pedagogy. Actor's formation. 
SUMÁRIO

ALGUMAS BASES PARA UMA FORMAÇÃO GLOBAL DO ATOR 28

2.1 Unitas multiplex e o conhecimento pertinente 28

$2.2 \quad$ Nosso Mundo Líquido 36

2.3 Uma Pedagogia para a Formação do Ator 41

3.1 De que música estamos falando?

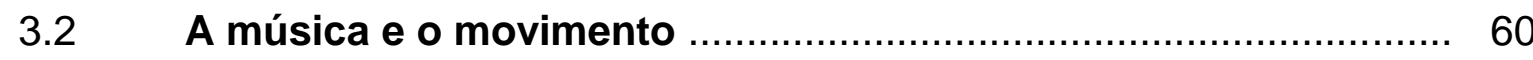

3.3 Musicalidade ….................................................................... 65

4 A MUSICALIDADE NA POÉTICA DE MEYERHOLD ...................... 70

4.1 Bebendo Musicalidade na fonte ….............................................. 70

4.2 Reação ao Naturalismo.................................................................. 74

4.3 Teatro de Feira e Teatro de Convenção ............................... 80

4.3.1 Teatro de Feira ou Balagan........................................... 81

4.3.2 Teatro de Convenção..................................................... 87

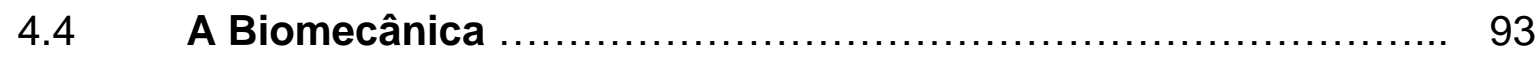

4.5 A Musicalidade na pedagogia meyerholdiana …....................... 107

4.5.1 Situando o leitor ..................................................................... 107

4.5.2 A prática musical em Meyerhold ..................................................... 110

4.5.3 Um Teatro Musical ................................................................ 119

$5 \quad$ CONSIDERAÇÕES FINAIS .................................................. 128

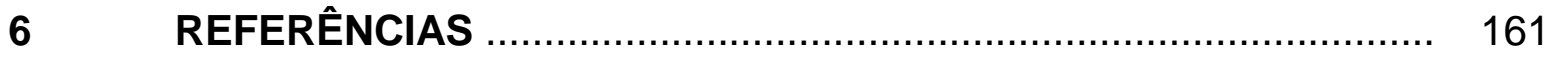

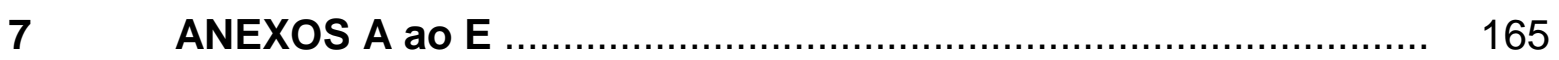




\section{INTRODUÇÃO}

O teatro é uma arte e, ao mesmo tempo,

Talvez algo mais que uma arte

Vsévolod Meyerhold ${ }^{1}$

Uma pesquisa científica é, na maior parte das vezes, fruto do mergulho do pesquisador num universo de informações delimitadas e organizadas a fim de produzir algum resultado. Em artes cênicas isso, por si só, pode representar uma teorização inatingível, pois o estudo teórico de um tema pode distanciar o pesquisador da sua prática e, desta forma, tornar-se inaplicável.

Nosso objeto nesta pesquisa é o ator. Enquanto ser vivente e enquanto ser que atua. É no ator que se dá a concretude da arte teatral, para onde convergem as expectativas do público, ainda que diante de um belíssimo espetáculo de luzes, sons e cenários. Mesmo no mundo atual, tão vivo de possibilidades tecnológicas e recursos que podem ser utilizados a serviço da cena, o material humano se destaca.

Talvez em decorrência dessa avalanche de "progresso", parece uma necessidade do homem atual, falar e fazer tudo ao mesmo tempo. Esse homem é resultado de inúmeros movimentos e diversas conquistas que o colocam em xeque para dar conta de tudo e de si mesmo. Somos acionados constantemente a saber e a opinar sobre tudo, sem que nos seja dada a menor oportunidade para ficar de fora dos últimos lançamentos sobre qualquer coisa. Não se trata apenas da sociedade do espetáculo, esta se fundiu com a sociedade do consumo. E a velocidade da vida é tal, que já é num upgrade dessa fusão que vivemos.

\footnotetext{
${ }^{1}$ Apud PICON-VALLIN, Béatrice. A Arte do Teatro: entre a tradição e a vanguarda: Meyerhold e a cena contemporânea. Org. Fatima Saad. Rio de Janeiro. Teatro do Pequeno Gesto: Letra e Imagem, 2006, p.67
} 
Experimentamos, desde o século $\mathrm{XX}$, uma voraz evolução científica e tecnológica que refletiu em todas as outras áreas do fazer humano, redefinindo as condições sobre as quais vivemos. A diminuição das distâncias e a possibilidade de acesso às mais variadas informações em tempo real criou necessidades diferentes ao ser humano que passou a devorar a vida com impressionante rapidez.

A questão levantada não é a qualidade das coisas que o homem moderno faz; se ao falar no celular enquanto dirige comete infrações e põe em risco a vida das pessoas à sua volta. Ou se ao querer "estar por dentro" de tudo que se passa nas vanguardas teatrais, as pessoas não amadurecem nada do que aprendem e experimentam muito pouco de tudo, mas nada em profundidade. Isto é consequência do momento em que vivemos e, ainda que não endosse tais atitudes, não cabe aqui aprofundar o debate sobre elas, mas sim detectá-las entendendo as como propulsoras de novas experimentações artísticas. Cremos que assim, será possível aprofundar o conhecimento sobre elas, para, então, combatê-las, se for o caso.

Nossa motivação é essa necessidade do homem pelo novo, pelo atual e por tudo ao mesmo tempo e os reflexos que isso causou no Teatro. Cremos que daí vem o movimento de incorporação em massa da música ao fazer teatral pelo homem moderno. É no contexto do "fazer tudo ao mesmo tempo" para poder viver plenamente o hoje e o agora que o Teatro passa a utilizar com maior frequência elementos não verbais, ocasionando uma avalanche de experimentações físicas em relação ao corpo e à voz e valendo-se da música para explodir essa multiplicidade de sensações que pretende exprimir em nosso século.

É isso que traz a necessidade de um novo ator, que esteja pronto para a experimentação cênica e que seja capaz de comunicar suas vivências e sensações por diferentes linguagens. Trata-se de um ator pronto para o jogo cênico, não importando como ele ocorra, mas um ator consciente de seu papel e autônomo em suas escolhas. Aí está a grande crise 
da atuação, no afã de dar conta de todas as coisas ao mesmo tempo o ator acaba perdendo sua capacidade de reflexão sobre tudo que faz e, assim, torna-se mercadoria.

As evoluções científica, econômica, social e cultural, culminaram com as quebras de barreiras e diminuição das distâncias $\mathrm{e}$ isso possibilitou que o ocidente e o oriente trocassem experiências e pudemos experimentar, de forma mais plena que antes, o fazer teatral oriental, para o qual a música tem papel muito importante, mesmo dentro de sua forma tradicional de construção, sendo inerente à cena.

O processo de incorporação da musicalidade se faz necessário para devolver a esse ator, dominado pelo fluxo do mundo pósmoderno, sua emancipação.

Nesse sentido, "compreender a encenação como um ato musical é compreendê-la do ponto de vista dessa nova teatralização, é integrar ao pensamento cênico um tipo de pensamento estrutural, que se apoia nos fenômenos sonoros e temporais (um pensamento de natureza musical), passando a contemplar com maior ênfase a estrutura sonoro-temporal da cena e relativizando a perspectiva tradicional, que se apoiava principalmente no dado espacial." 2

Para que essa compreensão possa se dar plenamente no ofício do ator, ela deve estar presente desde a sua formação. Aliando mecanismos musicais para que seu trabalho possa ser organizado musicalmente, não apenas sofra incidências musicais pontuais. É desejável dar uma boa base musical ao ator, mas também que ele passe a agir musicalmente em relação a todo fazer teatral.

Até onde investigamos, as teorias desenvolvidas para que o ator realize seu trabalho utilizam-se, quase sempre, do canto e/ou da dança como capacitadores ou como preparadores de uma situação na qual

\footnotetext{
${ }^{2}$ CINTRA, Fabio. A Musicalidade como Arcabouço da Cena. Tese de Doutorado. CAC/ECA/USP. São Paulo, 2006, p. 27
} 
sequer estão presentes. Os mais respeitados pesquisadores das artes cênicas já abordaram a utilização de recursos como o canto e dança como apoiadores da cena e do trabalho do ator, no entanto a prática cotidiana faz com que esses elementos, na construção da cena e do espetáculo passem a ser ignorados, ficando sua utilização restrita a momentos em que somente se cante e/ou se dança e todo o trabalho de interpretação normalmente é feito sem se levar em conta os instrumentos obtidos pela música utilizada.

Assim, esta pesquisa aborda o desenvolvimento de um fazer teatral a partir da musicalidade no corpo do ator, nascidos dos diálogos possibilitados pelos estudos que desenvolveremos a partir dos ensinamentos de V. Meyerhold, em fricção com as visões sobre música de M. Schafer e as teorias desenvolvidas por Dlacroze, sedimentadas a partir de práticas e estudos realizados com a professora Yedda Chaves.

A inestimável contribuição de Meyerhold para a arte, que, parece, até hoje não foi completamente assimilada, dadas diversas circunstâncias históricas e geográficas. É fonte potente de um fazer teatral extra-cotidiano que vai de encontro com as necessidades contemporâneas. Os motivos históricos da não assimilação de seus ensinamentos são determinantes para seu desconhecimento, mas não compõem nosso objeto de estudo. É preciso continuar o movimento de repensar sua obra para o ator de hoje.

Podemos apontar duas problemáticas que alimentam a necessidade desse resgate, colocando a obra de Meyerhold em contato com o fazer teatral atual, e aguçando a necessidade do estudo da musicalidade: a) A formação do profissional do teatro é segmentada não incentivando o estudo e experimentação conjunta do que é aprendido; b) o fato de que há certa ignorância musical na formação desse ator, o que prejudica sua visão de seu ofício como uma composição.

No ensino do teatro, os atores são expostos a aulas separadas de corpo, dança, voz e canto, desenvolvendo isoladamente cada 
uma dessas vertentes do trabalho do ator. Quando chega o momento de juntar tudo, a fusão normalmente não acontece. Isabel Setti, em seu artigo "O corpo da palavra não é fixo, deixa-se tocar pelo tempo e seus espaços"3, nos mostra que uma das maiores dificuldades do ator é aprender separadamente as técnicas vocais de fala e canto - e estendo aqui este entendimento para as aulas de corpo e dança - e depois se ver solitário na unificação de toda a teoria que aprendeu para a produção de um resultado prático.

Béatrice Picon-Vallin, abre seu texto "A Música no Jogo do Ator Meyerhodiano" com uma citação do mestre que diz: "trabalho dez vezes mais facilmente com um ator que ama música. (...) É preciso habilitar os atores à música desde a escola".

A partir da abordagem artística de Meyerhold, passamos a refletir sobre seu modo de pensar e fazer teatro em colaboração com outros artistas, situando a problemática da utilização pelo ator do corpo, mente e cérebro, conectados.

Outro ponto importante: devemos ampliar nossa visão de produção sonora e entender que capacitação musical não está ligada, necessariamente, ao manejo virtuoso de um instrumento, mas a conceitos mais amplos de música, que teremos a oportunidade de desenvolver. Portanto há diversas formas de instrumentalizar musicalmente $o$ ator para que possa compreender seu ofício enquanto composição.

Desta forma, instigados por um fazer teatral que atenda à cena do século XXI, dotada de todas as possibilidades técnicas e artísticas e no intuito de instrumentalizar ${ }^{4} \mathrm{o}$ ator para a teatralidade pela encarnação da música.

\footnotetext{
${ }^{3}$ Revista Sala Preta Número 7 - Publicação do Programa de Pós-Graduação em Artes Cênicas da Escola de Comunicações e Artes da USP.

${ }^{4} \mathrm{O}$ termo "instrumentalizar" aqui refere-se a aquisição de repertório que possibilite a emancipação do ator em relação à composição cênica e não ao sentido de formatá-lo para uma prática determinada.
} 
Para isso desenvolvemos os capítulos a seguir de forma a desenvolver, nos primeiros, conceitos e saberes que serão conectados aos demais no curso do texto, mas, principalmente, nem sempre de forma racionalizada.

No capítulo 1, Algumas bases para uma formação global do ator, procuramos trazer os elementos essências para a compreensão do ser humano que habita o ator (ou vice versa). A palavra global que consta do título, não tem o sentido de globalizante ou qualquer próximo a esse, mas refere-se a uma visão mais ampla sobre o ator e sua formação, que seja capaz de considerar diversos fatores concomitantemente, a um só tempo.

Este capítulo comporta 3 itens, "Unitas multiplex" e o conhecimento pertinente, Nosso Mundo Líquido e Uma pedagogia para a formação do ator. Todos lançam nossos olhares para os processos a serem instaurados em relação à formação do ator, buscando detectar os fatores que incidem sobre as formações atualmente em curso.

O humano enquanto ser complexo, comporta múltiplas possibilidades, o que está efetivamente presente no ator. O curioso é que ao desconsiderarmos o homem enquanto ser múltiplo, necessitamos de um esforço muito maior para desenvolver no ator uma multiplicidade, que já estaria dada pela sua própria condição de humano.

Uma formação deve também ser contextualizada. O contexto pode alterar os sentidos das coisas, já que elas são "tecidas juntas" ali, passando a fazer sentido assim, não devem ser consideradas separadamente. A disjunção na formação deve ser combatida, pois segrega elementos que foram concebidos juntos e, portanto, assim devem ser considerados.

Esse complexo sistema que é o homem, possui basicamente três frentes de inteligências que competem e se auxiliam nas percepções do mundo: a racional, ligada à capacidade cerebral de organizar 
as informações e os saberes, a afetiva, relacionada às emoções e às relações estabelecidas entre o homem e o mundo, e a de pulsão, que fomenta o instinto e a visceralidade.

O saber disjuntivo desconsidera esse homem como um todo e passa a observar apenas suas partes, perdendo a noção do todo o homem deixa de se considerar responsável por ele e criamos individualismos e mais especialização fechada. Buscamos uma formação que dê conta desse homem e se insira no mundo líquido em que vivemos.

Parece que perdemos a noção estrutural do mundo. Não que ainda exista uma visão linear das relações e dos acontecimentos, mas a velocidade dos tempos atuais nos faz crer que as coisas se ligam como em uma rede, portanto com apenas alguns pontos de contato, quando, na verdade, são parte da mesma estrutura. Isso faz com que um fato ocorrido no Japão nos afete diretamente no Brasil. Da mesma forma, o trabalho de um profissional do teatro está ligado estruturalmente ao dos demais, afetando-o.

Os antigos modelos teatrais não dão conta de toda essa velocidade e multiplicidade, assim passam a explorar de forma desordenada e desesperada todos os recursos possíveis para tornar a cena mais interessante ao homem de hoje. Nesse movimento, muitas vezes acabam por esquecer que esse homem deseja fazer parte do mundo e, portanto, da cena. Nessa corrida pelas experimentações tecnológicas aglomeradas em cena a música é usada e abusada, mas não no melhor sentido.

O ator precisa dar conta desse mundo, de si e de seu trabalho, expressando-se por diversas linguagens (como a música e a dança). Não há, porém, um elemento organizador dessa salada de recursos. Nossa proposta é compreender a encenação como ato musical e o ator como compositor de sua própria atuação. Para isso o ator deve conectar a imaginação à ação, ou como diria Meyerhold, colocar em trabalho o "corpomente". 
No entanto é preciso abrir algum espaço dentre esse turbilhão de informações e necessidade que nos assola para criarmos uma verdadeira experiência. O primeiro desafio do ator, antes mesmo de dar conta da musicalidade com seu corpo-mente-emoção, é dilatar os espaços no tempo para acolher experiências. E essa relação espaço-temporal pode ser resolvida a partir da música.

E se o teatro é a arte onde se presentifica o elo físico entre obra de arte e público, é o ator quem concretiza essa experiência teatral.

Os sentidos do homem, seja ator, encenador, plateia ou outro, porque todos humanos, são coexistentes, agem em comunhão, marcada por complementaridade e conflito. Porém, como a formação do ator não leva isso em conta, produz uma percepção muito fechada sobre ele e sobre o outro, que nem sempre é possível de se completar em sua mente.

Esse ator, refém da disjunção e da liquidez do nosso tempo, recebe uma formação pautada na imitação do real, caindo na reprodução (pela disjunção e liquidez do tempo), enquanto caberia metamorfosear a realidade em crítica.

Meyerhold propõe um realismo que transponha a imitação da vida, mas que a enriqueça a partir de uma composição que se aperceba daquilo que pode ser revelado a partir dela

Nosso desafio? Uma formação para que 0 ator possa trabalhar a técnica, mas tenha autonomia para alcançar à poética. Emancipado a ser compositor de suas ações cênicas com consciência de seu papel social, mantendo princípios éticos e estéticos.

Ao ator, cabe permitir a exposição dessa multiplicidade em arte a partir de si próprio. Utilizar técnica/treino para alcançar à poética, isto é, instrumentalizar o ator (com o objetivo de ampliar seu repertório incorporado e não de promover a aquisição de um turbilhão de informações, das quais não dá conta), retirando dele a crença de que atuar é agir conforme as sensações 
do momento. Muitos atores buscam sentir as emoções, mas acabam esquecendo que é ao público que devemos emocionar.

Desta maneira, propor uma formação do ator onde friccionem a racionalidade, a afetividade e a pulsão, pautada na técnica que transbordará em poética é a proposta a ser afinada ao longo dos anos.

O exemplo de Meyerhold é muito bom nesse sentido. Tomou o ator como símbolo da cena e propôs que a técnica fosse um instrumento contra o procedimento da ilusão. Não precisamos de fórmulas ou cartilhas, mas precisamos despertar no ator a sensibilidade para alguns elementos fundamentais em seu trabalho, como por exemplo, o humano, o espaço, a criação teatral.

No Capítulo 2, Musicalidades, buscamos enfrentar o árduo desafio de conceituá-la. Nem no universo da Música, enquanto linguagem, isso costuma ser feito, mas entendemos ser importante para a compreensão que dispensamos ao termo nesta obra de pesquisa. Ele também está dividido em três partes: De que música estamos falando?, A Música e o Movimento e Musicalidade.

A música é elemento ancestral na vida humana e , historicamente, um elemento que o homem utiliza para se ligar a Deus. Dessa forma a música contém em si o elo fundamental entre o humano e o divino, o pagão e o sagrado.

A música está em tudo e é constitutiva desse todo, uma vez que é inerente à nossa existência a questão do tempo, do ritmo e das alturas dos sons e das coisas. Mas são ligada à escuta as escolhas musicais que fazemos e, portanto, o que ouvimos influencia diretamente em nossa visão musical do mundo.

A paisagem sonora do mundo muda constantemente, mas no último século passou por alterações significativas, trazendo para o ouvido humano um ambiente acústico radicalmente rico em sons e ruídos. 
Nesse contexto, "música" será considerada uma organização de sons com a intenção de ser ouvida, pois há tantos sons a nossa volta que podem até realizar construções melódicas, que será nossa intenção em ouvi-los e fazer deles música que os transformará em tal.

$\mathrm{E}$, se esta é a música que levaremos em consideração, o trabalho deve relacionar musicalidade a esta realidade musical, para só então utilizá-la. Aliás, a melhor utilização da música no espaço cênico, embora todas as demais sejam igualmente importantes, é enquanto fator organizador do tempo no espaço, pois este é um grande desafio.

A paisagem sonora é fundamental na compreensão da música, mas Schafer alerta que "ouvir não é 'ser tocado por sons' que chegam ao meu ouvido sem atingir a minha consciência" ${ }^{5}$. Por outro lado a consciência das sonoridades, ainda quando fundos sonoros, se dá pela racionalidade (reflexão), o que nem sempre alcançamos quando estamos operando apenas no "ouvir".

Um dos pontos importantes deste capítulo diz respeito às escutas, compreendidas em quatro níveis: escutar, ouvir, compreender e entender. Se sem escuta não há música, é preciso adentrar nesses quatro universos para desenvolver uma compreensão musical mais apurada.

O trabalho não busca investigar se há algo em comum com a música e o teatro. O que nos interessa nessa relação não são as práticas artísticas por si, nem seus produtos, mas os aspectos que as concretizam no artista e no público.

Música resulta do movimento que faz vibrar algo. Música é movimento. Existem sons audíveis e sons não audíveis, assim a música pode estar presente mesmo quando não a escutamos.

Uma questão importante é a da origem do som. O som é onda que decorre da vibração de um corpo qualquer, propagada no espaço e

\footnotetext{
${ }^{5}$ SCHAEFFER, Pierre. Tratado de los Objetos Musicales. Madrid: Aliaza, 1966, p. 82
} 
captada pelos ouvidos, que a transmitirão ao cérebro para construções cognitivas no campo da racionalidade, da afetividade ou ainda da pulsão. Não há som sem pausa, pois é o movimento de sua presença e sua ausência que produz a vibração capaz de materializá-lo. Com isto temos que toda presença e ausência que formam o som capaz de produzir música se dá num corpo qualquer. $O$ corpo a partir do qual se pretende produzir som influencia diretamente à música que será produzida. No teatro, o corpo é o ator

No capítulo nos propomos a investigar essa corporeidade a ser produzida no teatro pelo ator e que está em seu próprio corpo. É no corpo do ator que teremos a possibilidade de fazer com que a música seja percebida com todos os sentidos e não apenas com a audição e que é necessário que essa presença musical do ator se alastre para todo o espaço cênico, fazendo constantemente música, audível e não audível.

A partir dessa investigação pretendemos a compreensão de que a concretude da musicalidade se dá também no ator e nas pessoas com quem se relacionar, portanto a partir dela é possível se conectar ao público.

Se a vida apresenta-se como um processo contínuo e alternante entre as experiências propostas e as ocorridas, resultando em saberes acumulados ou descartados, em níveis racionais, afetivos e pulsantes, é necessário compreender que em cada etapa da formação do homem ele ressoa uma musicalidade.

Falamos também sobre os trabalhos rítmicos desenvolvidos por Dalcroze e que serviram de base para a compreensão do teatro a partir da musicalidade já em Stanislavski e, depois, Meyerhold.

A percepção da importância psicológica do movimento e sua relação com os aspectos afetivos e intelectuais levou Dalcroze a desenvolver seu Método de educação musical.

Do trabalho de Dalcroze, destacamos, aqui, duas ideias: 
a) Primeira é da incorporação ou encarnação dos saberes, pelo qual o pensamento se alastra por todo o corpo e passamos a multidirecionar a escuta, em sentido amplo, para nossos órgãos e emoções, sem perdêla dos ouvidos e do trabalho mental;

b) Segunda é estarem presentes cinco elementos: corpo, espaço, tempo, energia e ritmo.

Tais ideias são essenciais aos processos de incorporação da musicalidade no trabalho do ator.

Já o Capítulo 3, A musicalidade na Poética de Meyerhold, deve ser compreendido sobre alguns aspectos principais. Por constituir a fonte primária do nosso trabalho entendemos ser necessário dar-Iha uma atenção especial, introduzindo o leitor em determinados conceitos e princípios, para que pudesse completar sua leitura em consonância com nosso percurso de pesquisa.

Dividimos o capítulo em dois momentos. No primeiro abordamos as bases sobre as quais Meyerhold debruçou seu trabalho (itens 3.1. a 3.4.), traçando paralelos entre a musicalidade e o encenador-pedagogo. No segundo (item 3.5.) abordamos a musicalidade propriamente dita.

Como tudo possui uma fonte, Meyerhold, tendo sido aluno de Stanislaviski, traz dele muitos dos fundamentos que desenvolve. Então, entendemos ser necessário compartilhar com o leitor informações sobre ele.

Stanislaviski criou um Sistema pautado em vários princípios, dentre os quais: destacamos as "Ações Psicofísicas", por sua relação direta com a musicalidade. Por esse princípio, é necessário que 0 ator traduza a sua imaginação das circunstâncias de forma artística, traga esse mundo imaginário para o aqui e o agora, em ação. 
Toda esta elaboração sobre o movimento, a sonoridade, o tempo e o ritmo, como o próprio Stanislaviski cita em suas obras, bebe na ideia de musicalização e rítmica (esta a partir de Dalcroze).

Para ele, o artista precisa encontrar a si mesmo, já que o sentimento vivo é do ator e não da personagem. Na ausência dele não há "se" mágico, e consequentemente não há personagem. Assim, é a musicalidade do ator que está em jogo, alternando-se nos tempos propostos pelo texto e nos descobertos por ele próprio.

Seria errôneo considerar a ação física só como um movimento plástico que expressa à ação. É uma ação autêntica, logicamente fundada, que persegue uma finalidade concreta e que, no momento de sua execução, se converte em uma ação psicofísica

Mas Stanislaviski desenvolvia estudos muito ligados a uma encenação naturalista. Para Meyerhold, o naturalismo não é interessante uma vez que apenas reproduz o cotidiano, não sendo capaz de aprofundá-lo. Isso forma atores que se acostumam a serem meros executores de ações previamente estabelecidas ou criadas a partir do modelo de repetição.

A prática meyerholdiana funda-se em princípios que buscam um ator que seja capaz de tomar uma posição diante da personagem (ou tipo), rompendo a quarta parede e jogando com o público. Isso por si só já significa um distanciamento evidente do naturalismo.

Um ator que fosse autônomo no conteúdo e na forma. Que fosse capaz de compreender a encenação, o texto e seu próprio papel de criador, possibilitando diálogos da obra teatral com o público.

A ele não interessava mostrar o cotidiano em si, mas aprofundar essa visão escancarando a monstruosidade de ser humano. Com isso, ele resgata a teatralidade da cena. Coloca em cheque a mimese e lança a necessidade de um olhar sobre o público. 
Mas como preparar o ator para isso? Ao privar o ator do gesto vivo, realístico, ao impor uma entonação "artística", ao invés da entonação "lógica"

Era necessária a compreensão de uma nova musicalidade para o trabalho do ator, assim como acontece hoje. Quebrar com a obviedade da música da vida cotidiana, somente se poderia alcançar pelo mistério e pelo inacabado. $\mathrm{O}$ oposto disso, o teatro naturalista, transforma a arte teatral numa ilustração das palavras do dramaturgo.

Meyerhold, mesmo sendo um vanguardista por excelência, sempre se preocupou em possuir como base de trabalho a tradição. Nesse movimento, traz a prática do Teatro de Feira e resgata a convenção teatral, impregando-lhe um sentido ainda mais adequado à fomentação da teatralidade.

Se, por um lado, no teatro burguês, os gêneros se diferenciam uns dos outros, no "teatro de balagan", uma forma sintética deles é conservada, enquanto seus atores possuem uma formação tão ampla em possibilidades quanto profunda em conhecimento da técnica.

O Balagan é uma expressão fortemente polifônica na forma e no conteúdo, contando com uma fricção necessária entre as atividades de todos os artistas envolvidos. A partir dele a imitação da vida perde sentido e podemos dar lugar à arte da vida. Há uma concepção diferente, de um ser múltiplo.

Em relação ao Teatro de Convenção, Meyerhold pretende, dentre outras coisas, por fim na desarmonia entre os profissionais envolvidos no evento teatral. Nesse exercício desenvolve um sistema de Teatro em Linha Reta, pelo qual o ator abre livremente sua alma ante o espectador, tendo aceitado em si mesmo a arte do diretor, como este último teria aceitado em si a arte do autor. Há uma sequencia horizontal composta pelo autor, seguido do encenador, do ator e finalmente do espectador. 
A inclusão do público no evento teatral, representa o advento do $4^{\circ}$ criador, e com ele duas importantes colaborações ao teatro mundial. A primeira é a necessidade de participação do público para que se complete o evento teatral. A segunda é a necessidade de uma obra porosa que permita o diálogo com o público, que a completa.

Toda essa estrutura possibilita um novo olhar para a atuação. O ofício do ator se dá agora em outros planos. "... construídos a dicção e os movimentos dos atores no ritmo, aproxima a possibilidade do renascimento da dança, e a palavra em tal teatro facilmente se transforma em grunhido cantado, em silêncio cantado." ${ }^{6}$

Neste capítulo não poderíamos deixar de abordar, ainda que sucintamente, a Biomecânica. Não como um conjunto de regras, mas como fontes ao trabalho do ator sobre si mesmo, emancipando-o para um teatro que emergia e que, em nosso tempo, salta das salas de espetáculo para toda sorte de espaço.

Com a Biomecânica, Meyerhold atinge um teatro sintético, fazendo nova leitura das técnicas de atuação. São exercícios essencialmente musicais, que trazem em si a emanação de musicalidade a ser compreendida não apenas pelo cérebro, mas também pelo corpo.

Segundo a professora Yedda, a Biomecânica, a partir das contradições que possibilita, revela a arte do ator, combatendo as reações automáticas e permitindo a aquisição de uma consciência maior cobre o material mais importante de seu trabalho, seu corpo. ${ }^{7} \mathrm{~A}$ partir disso o ator meyerholdiano ganha autonomia e não mais se submete ao material de trabalho.

O fundamento da Biomecânica é movendo-se a ponta do nariz, o corpo todo se move. Isso significa que à menor tensão o corpo todo

\footnotetext{
${ }^{6}$ MEYERHOLD, V. E. Do teatro. Trad. Diego Moschkovich. São Paulo: Iluminuras, 2012, p. 88

${ }^{7}$ CHAVES, Yedda. (informação verbal)
} 
reage. Não é tolerado nada de casual, o objetivo é desenvolver a máxima consciência do ator, com precisão.

Ele explora diversas possibilidades de relação com a música para o corpo do ator e para o corpo da cena. Desde arranjos e sonoplastia em diálogo com as falas ou os movimentos dos atores, até a utilização de danças e exercícios rítmicos, além de incentivar os acentos e pausas, sempre com vistas a encontrar possibilidades de polifonias.

Nesse capítulo, buscamos mostrar que a música é um dos melhores recursos para que $o$ ator consiga estabelece $o$ jogo entre tempo e espaço. Então, a música não é trabalhada apenas no tempo, penetra o teatro, tanto como material quanto como princípio organizador da cena.

Mas o processo de musicalização não é restrito ao trabalho do ator. Devem preencher todos os profissionais envolvidos na criação.

Enquanto formador de atores e de encenadores, Meyerhold buscou, incansavelmente, a penetração musical nas matérias dos cursos que formulou ou participou. Podem-se chamar o ator meyerholdiano de musical, exatamente pelas dissonâncias e consonâncias encontradas entre teatro, musica e todas as outras linguagens artísticas friccionadas em sua formação e no seu trabalho cênico. Seu caminho o conduz a um Teatro Musical

Nesse teatro, a música não ilustra ou reforça as ações, ele é a sua base, sua estrutura, uma vez que, com o corpo, o ator a realiza para executar as ações que the foram designadas. Além disso, deve haver musicalidade no texto, no gesto, no olhar, na iluminação etc.

A música sempre estará presente na obra meyerholdiana, audível ou não. Com isso o espetáculo se organiza dentro da multiplicidade em que é composto. 
Munido dessas informações iniciais, esperamos poder provocar o leitor a refletir sobre o teatro, o ator, a formação desses profissionais, mas principalmente sobre si mesmo, enquanto humano e amante da arte teatral. 


\section{Algumas Bases para uma formação global do ator}

O ator é um pássaro que, com uma das asas, desenha na terra e, com a outra, alcança o céu Vsévolod Meyerhold ${ }^{8}$

\subsection{Unitas Multiplex e o Conhecimento Pertinente}

Qualquer trabalho sobre o ator é um trabalho sobre o humano; assim, escrever sobre o trabalho do ator é escrever sobre o homem e a mulher que atuam, compreendendo que a ação de atuar não fica restrita aos momentos em que estejam num palco ou num outro espaço para encenação, mas perpassam para sua existência enquanto experiência constituinte daquele corpo-mente vivente.

A situação de ser ator não é restritiva ao momento da ação do ator em cena e sim da pessoa que atua. $O$ trabalho do ator é sobre si mesmo e o teatro deve ser feito pelo homem vivo, que executa sua arte: por isso mesmo todas as circunstâncias tecidas em relação a quem é interferem direta e indiretamente em seus fazeres profissionais.

O mesmo se dá em relação à sua formação. Uma escola que funde seu trabalho na mimese passiva de valores que buscam a reprodução da vida resulta num ator diferente de outra que creia na musicalidade como instrumento para a conquista de outros dizeres. E isso produz um teatro totalmente diferente, pois que o teatro não é apenas o ator, mas sua síntese se faz nele.

Portanto, nosso estudo e debate se fazem sobre o mais volátil dos materiais, o humano. A compreensão desse ator enquanto ser humano possibilita alcançar uma qualidade diferente no trabalho, em diversos níveis.

\footnotetext{
${ }^{8}$ Apud PICON-VALLIN, Béatrice. 2006. Op. cit. p. 23
} 
Nas palavras de Edgar Morin, o "humano é um ser a um só tempo plenamente biológico e plenamente cultural, que traz em si a unidualidade originária. É super e hipervivente: desenvolveu de modo surpreendente as potencialidades da vida. Exprime de maneira hipertrofiada as qualidades egocêntricas e altruístas do indivíduo, alcança paroxismos de vida em êxtases e na embriaguez, ferve de ardores orgiásticos e orgásmicos, e é nesta hipervitalidade que o Homo sapiens é também Homo demens"'.

Escolhemos o livro de Edgar Morin como base para este tópico, por entender fundamental a compreensão do homem de forma global, como caminho para um trabalho do ator, com o ator e para o ator enquanto ser vivente de um planeta e componente das questões deste lugar.

É interessante refletir sobre o fato de que se por um lado toda a carga cultural do homem o difere dos demais primatas, pois o torna capaz de aprendê-la, conservá-la, transmiti-la e, por isso, criar normas em torno dela, por outro lado se iguala a eles na animalidade e instinto. Tudo isso coexiste integralmente em cada um de nós. Somos $100 \%$ cada parcela de nós mesmos: se dividimos nossas principais atividades vitais em 5 , no momento em que vivemos uma delas, somos integralmente ela, sem deixar de ser as demais e não seremos $1 / 5$ de nós em momento algum. Por exemplo, se sou, pai, filho e namorado, sou as três coisas integralmente a todo instante, mesmo que não esteja acionando conscientemente alguma delas. Agregue-se a isso o fato de ser concomitante e plenamente ator, professor, diretor e advogado. Caso conseguisse extrair de mim uma dessas partes, já não seria mais eu.

A ciência explica isso de uma forma mais técnica, que nos auxiliará a alcançar outro lugar nessa leitura, quando fala de uma tríade bioantropológica: cérebro/mente/cultura. Representada pelo paleocéfalo, mesocéfalo e córtex, faz emergir outra face da complexidade humana, que

\footnotetext{
${ }^{9}$ MORIN, Edgar. Os sete saberes necessários à educação do futuro. 3 ed. Brasilia: Cortez, UNESCO, 2001, p. 60
} 
integra a animalidade na humanidade e a humanidade na animalidade ${ }^{10}$. As relações entre as três instâncias são não apenas complementares, mas também antagônicas, comportando conflitos bem conhecidos entre a pulsão, o coração e a razão. Não ocorreria uma hierarquia entre as instâncias, mas sim uma atividade instável, com complementaridade, antagonismos ${ }^{11}$.

Somos seres integralmente racionais, integralmente afetivos e integralmente pulsantes, portanto, a racionalidade não dispõe de poder supremo sobre nossos saberes, já que, segundo Morin, é uma instância concorrente e antagônica às outras instâncias de uma tríade inseparável, e é frágil: pode ser dominada, submersa ou mesmo escravizada pela afetividade ou pela pulsão. ${ }^{12}$

Esses conflitos entre razão, afeto e pulsão nos fazem compreender que a afetividade está diretamente ligada à inteligência e ao saber. Portanto, a ciência chegou a um lugar, que neste trabalho não cabe aprofundar, da compreensão de que existem fundamentalmente duas inteligências principais: a Racional e a Afetiva $^{13}$.

Há, ainda, uma terceira inteligência, menos explorada conscientemente, mas tão acionada quanto às demais: a pulsão. Essa inteligência ancestral, primitiva e visceral, que transborda nos momentos em que não obtemos resposta rápida das demais, ou ainda anterior a elas em situações de clamor ou de perigo, quando a chamamos por vezes de instinto.

\footnotetext{
10 Morin descreve algumas características neurofisiológicas para conceber o cérebro como uma "máquina hipercomplexa", dentre elas o cérebro triúnico, para o qual McLean elaborou uma teoria de regionalização cerebral, de acordo com elementos filogenéticos. Assim, haveria:

O paleocéfalo (herança reptiliana), constituído pelo hipotálamo - sede da agressividade, do cio, das pulsões primárias;

O mesocéfalo (herança dos mamíferos antigos), com o sistema límbico - aspectos da afetividade e da memória de longo prazo;

O córtex, com os hemisférios cerebrais que se hipertrofiam no homem (o neocórtex) - lugar das aptidões associativas, lógicas e estratégicas. Assim, haveria uma unidade triunitária, que permite encarar o cérebro como complexo.

(MORIN, Edgar. O Método III. O Conhecimento do Conhecimento. Europa-América, 1987)

${ }^{11}$ Consulte: P. D. Mac Lean, The triune brain, in Smith (F. Q.) ed. The Neurosciences, Second Study Program, Rockefeller University Press, Nova York, 1970.

${ }^{12}$ MORRIN, Edgar, op cit. P. 61

${ }^{13}$ Edgar Morin, na obra citada, chama esta segunda de Inteligência Humana, mas entendemos que ambas coexistem e friccionam-se no humano, e estando a segunda ligada às percepções afetivas, a denominação que propomos aqui é mais adequada.
} 
Este é o humano onde podem conviver e confrontar o homo sapiens e o homo demens, a quem Morin chamou de Unitas multiplex, unidade e diversidade humanas, ambas encontradas em todos os traços de cada pessoa, psicológico, biológico, cultural, histórico e afetivo, os quais devem ser observados em sua totalidade e não em recortes isolados. É a unidade humana que traz em si os princípios de suas múltiplas diversidades. "Compreender o humano é compreender sua unidade na diversidade, sua diversidade na unidade. É preciso conceber a unidade do múltiplo, a multiplicidade do uno." ${ }^{14}$

Morin sustenta que o século XXI deverá abandonar a visão unilateral que define o ser humano pela racionalidade (Homo sapiens), pela técnica (Homo faber), pelas atividades utilitárias (Homo economicus), pelas necessidades obrigatórias (Homo prosaicus) ${ }^{15}$. O ser humano é complexo e traz em si, de modo bipolarizado, caracteres antagonistas:

- sapiens e demens (sábio e louco)

- faber e ludens (trabalhador e lúdico)

- empiricus e imaginarius (empírico e imaginário)

- economicus e consumans (econômico e consumista)

- prosaicus e poeticus (prosaico e poético)

O homem da racionalidade é também o da afetividade, o do mito e do delírio (demens). $\mathrm{O}$ homem do trabalho é também o homem do jogo (ludens). O homem empírico é também o homem imaginário (imaginarius). $\mathrm{O}$ homem da economia é também $\mathrm{O}$ do consumismo (consumans). O homem prosaico é também o da poesia, isto é, o do fervor, da participação, do amor, do êxtase. $\mathrm{O}$ amor é poesia. Um amor nascente inunda o mundo de poesia, um amor duradouro irriga de poesia a vida cotidiana, o fim de um amor devolve-nos à prosa.

\footnotetext{
${ }^{14}$ MORRIN, Edgar, op cit p . 63

${ }^{15}$ Idem, p. 65/66
} 
A partir dessa compreensão, é necessária uma formação que dê conta dessa complexidade. E que, sem abandonar os aspectos racionais de elaborações e propostas pedagógicas, consiga dar conta também dos saberes que nascem da afetividade e da pulsão. Não parece uma tarefa fácil, mas nesse caminho o próprio Morin elege alguns elementos que vêm se tornando invisíveis e levando o homem a perder sua humanidade e que, por isso mesmo, são pertinentes a qualquer formação:

- O contexto;

- O global;

- O multidimensional;

- O complexo.

Os dois últimos estão inseridos na ideia de Unitas multiplex, já citada. Se o ser humano é ao mesmo tempo biológico, psíquico, social, afetivo e racional, e a sociedade comporta as dimensões histórica, econômica, sociológica, religiosa, é fácil perceber que um conhecimento pertinente deve reconhecer esse caráter multidimensional e nele inserir estes dados: desta forma nem se poderia isolar uma parte do todo, nem as partes umas das outras.

Há complexidade quando elementos diferentes são inseparáveis constitutivos do todo (como o econômico, o político, o sociológico, o psicológico, o afetivo, o mitológico), e há um tecido interdependente, interativo e inter-retroativo entre o objeto de conhecimento e seu contexto, as partes e o todo, o todo e as partes e as partes entre si. Por isso, a complexidade é a união entre a unidade e a multiplicidade ${ }^{16}$.

O contexto diz respeito ao fato de que cada coisa pertence ao lugar onde está e não ao lugar onde poderia estar, porque foi "tecida" ali. Cada conceito aqui elencado, por exemplo, pode assumir características totalmente distintas em outros contextos e não há nada de

${ }^{16}$ MORIN. 1991. op cit. p. 38 
errado nisso, já que é inerente à multiplicidade das coisas. Exatamente por isso, aliás, se torna importante contextualizar.

Ao abordarmos o trabalho do ator a partir da musicalidade, traremos uma série de propostas e saberes friccionados que fazem sentido aqui, pois é onde foram tecidos juntos. Não devem ser observados isolados, desconsiderando sua natureza de unidade múltipla dentro deste tecido de ideias. No entanto, essas mesmas ideias, tecidas em outro contexto, podem assumir caminhos extremamente diversos. Assim também é o material humano. $\mathrm{O}$ ator é "tecido junto" em todos os aspectos que o compõem, portanto, não pode ser considerado de forma fracionada. Finalmente, as propostas feitas a ele e, bem como seus os conteúdos, devem considerar essa natureza, que é condição essencial do funcionamento da cognição.

Por sua vez, o global é "o conjunto das diversas partes ligadas a ele de modo inter-retroativo ou organizacional. Dessa maneira, uma sociedade é mais que um contexto: é o todo organizador de que fazemos parte. $O$ todo tem qualidades ou propriedades que não são encontradas nas partes, se estas estiverem isoladas umas das outras, e certas qualidades ou propriedades das partes podem ser inibidas pelas restrições provenientes do todo." ${ }^{17}$

Por isso é tão prejudicial à visão disjuntiva de qualquer formação, inclusive a do ator. A formação disjuntiva é aquela que segmenta, fraciona, separa os saberes, de forma que caberia a cada um, por si, empreender-se nas tentativas de juntá-los. Mas a disjunção é uma prática tão nociva, que impossibilita a visão global.

Um especialista em voz, por exemplo, que volta toda a sua atenção apenas para o aparelho fonoarticulatório, talvez não tenha a consciência de que esta voz possui um corpo e que no movimento desse corpo ganha e perde qualidades que alteram sua poética, pois em sua hiperespecialização tende a compreender os mecanismos da voz somente a

${ }^{17}$ MORRIN. 1991. op. cit. p. 39 
partir do seu local de pesquisa e, por vezes, não é capaz de compreender aquela pessoa de forma global, em sua unidade múltipla.

No ensino do teatro é muito comum que os atores sejam submetidos a aulas separadas de interpretação, corpo, dança, voz e canto, desenvolvendo isoladamente cada uma dessas vertentes de seu trabalho. Quando chega o momento de juntar tudo, a fricção normalmente não acontece.

Isabel Setti aponta que uma das maiores dificuldades do ator é aprender separadamente as técnicas vocais de fala e canto - e estendemos aqui essa dificuldade para as aulas de corpo e dança - e depois se ver solitário na unificação de toda a teoria que aprendeu para a produção de um resultado prático ${ }^{18}$.

Não que se trata de juntar as coisas, pois nossa hipótese de trabalho é exatamente no sentido de mostrar que são múltiplas e que, por terem sido tecidas juntas, não devem ser dissociadas. Daí tentarmos traçar aqui a ideia de uma "formação global", porque parte de fundamentos nãodisjuntivos.

Nossa educação, não de hoje, é totalmente disjuntiva. Ensina-nos a separar, fragmentar, de forma que os conjuntos acabam se tornando inteligíveis. A fragmentação e a especialização fechada criam profissionais que dão conta apenas de parcelas, pela própria incompreensão de que existe um todo. Isso leva a antinomias que separam cada vez mais os saberes e incentivam a formação de hiperespecialistas, fechados em seus estudos. E quanto mais fechados estejam, menos capazes de compreender as questões do todo.

\footnotetext{
${ }^{18} \mathrm{SETTI}$, Isabel. O corpo da palavra não é fixo, deixa-se tocar pelo tempo e seus espaços. Revista Sala Preta N. 7 - Publicação do Programa de Pós-Graduação em Artes Cênicas da Escola de Comunicações e Artes da USP, 2007..
} 
Se o homem é múltiplo, é imprescindível que ampliemos nossas percepções sobre o trabalho do ator. Só será possível compreender uma questão qualquer se pudermos nos atentar para o contexto, o global, o multidimensional e o complexo do qual é parte. E, por outro lado, se nos aprofundarmos somente na especificidade de uma única questão, é possível que nunca possamos alcançá-la.

Não fazemos aqui um discurso contrário ao saber racional. Nossa busca é para que possamos estender a compreensão de que a formação de um ator vai muito além da união de técnicas e criatividade. Não é apenas treino e prática com uma boa dose de emoção.

"Trata-se de entender o pensamento que separa e que reduz, no lugar do pensamento que distingue e une. Não se trata de abandonar o conhecimento das partes pelo conhecimento das totalidades, nem da análise pela síntese; é preciso conjugá-las. Existem desafios da complexidade com os quais os desenvolvimentos próprios de nossa era planetária nos confrontam inelutavelmente." ${ }^{19}$

Esse é nosso desafio, buscar uma nova compreensão do trabalho do ator, a partir da compreensão global do mundo.

${ }^{19}$ MORRIN. 1991. op. cit. p. 46 


\subsection{Nosso mundo líquido}

Em seu livro "Tempo Líquidos", Zygmunt Bauman escreve que a sociedade é cada vez mais vista e tratada como uma "rede" em vez de uma "estrutura": ela é percebida e encarada como uma matriz de conexões e desconexões aleatórias e de um volume essencialmente infinito de permutações possíveis.

"O colapso do planejamento, do pensamento e da ação a longo prazo e o desaparecimento ou enfraquecimento das estruturas sociais nas quais estes poderiam ser traçados com antecedência, leva a um desmembramento da história política e das vidas individuais numa série de projetos e episódios de curto prazo que são, em princípio, infinitos e não combinam com os tipos de sequências aos quais conceitos como 'desenvolvimento', 'maturação', 'carreira ou 'progresso' poderiam ser significativamente aplicados. Uma vida assim fragmentada estimula orientações 'laterais', mais do que 'verticais'. Cada passo seguinte deve ser uma resposta a um diferente conjunto de oportunidades e a uma diferente distribuição de vantagens, exigindo assim um conjunto diferente de habilidades e um arranjo diferente de ativos." ${ }^{20}$

A crescente necessidade do homem pelo novo, pelo atual e por tudo ao mesmo tempo e os reflexos que isso causou no Teatro, justificam a necessidade da incorporação real da música ao fazer teatral.

O professor Fábio Cintra fala dessa necessidade, por vezes fabricada, de se buscar o novo que ecoa em todo nosso tempo:

"a proposição de novos paradigmas abala 0 antigo pensamento e inaugura um século em que a própria transformação (portanto o conceito de mudança permanente, de instabilidade) se erige em valor. Essas alterações de perspectiva se sucedem cada vez mais

\footnotetext{
${ }^{20}$ BAUMAN, Zygmunt. Tempos Líquidos. Trad. Carlos Alberto Medeiros. Rio de Janeiro: Zahar, 2007, p . 9
} 
rapidamente no século $\mathrm{XX}$, e fazem da velocidade outra marca importante dessa mudança de paradigmas." ${ }^{21}$

É no contexto do "fazer tudo ao mesmo tempo" para poder viver plenamente o aqui e o agora que o Teatro passa a utilizar com maior frequência elementos não verbais, ocasionando uma avalanche de experimentações físicas em relação ao corpo e à voz e valendo-se da música para explodir essa multiplicidade de sensações que pretende exprimir em nosso século.

As novas estruturas cênicas e dramatúrgicas exploram formas que expressam em si mesmas um pensamento que não tem mais como ser comunicado através dos antigos modelos teatrais. Se o início do século XX propôs a revolução - política, econômica, intelectual e artística -, o início do século XXI revela a necessidade de assimilação daquilo que foi produzido pela integração globalizante, dentro e fora de cada área do saber, enfim, da fricção necessária entre as diversas formas de se expressar e das diversas ciências.

É isso que traz a necessidade de um ator que esteja pronto para a experimentação cênica e que seja capaz de comunicar suas vivências e sensações por diferentes linguagens. Se tudo e todos passam a fazer parte da cena, isso torna o teatro mais interessante para o homem, na medida em que o integra a ele.

"Abaixo o teatro do ator gramofone!" escreve Meyerhold em $1914^{22}$. O ator gramofone, "o ator 'cômoda' é aquele que não leva em conta nada além de sua natureza de ser falante, aquele em cuja boca se põe um texto como se põe um disco num gramofone. O elemento

\footnotetext{
${ }^{21}$ CINTRA, Fabio. A Musicalidade como Arcabouço da Cena. Tese de Doutorado. CAC/ECA/USP. São Paulo, 2006, p. 22.

${ }^{22}$ Referência ao artigo "As glosas do Doutor Dapertuto" em resposta ao texto de luri Aikhenwald, na revista "O amor das três laranjas", São Petesburgo, n.4-5, 1914 e retirado da obra referenciada no final do parágrafo.
} 
dramático em cena é, antes de tudo, a ação, a tensão da luta, as palavras aqui não passam dos harmônicos da ação."23

Meyerhold, que traz esse debate há um século, levanta questões que hoje necessitam de novas respostas, mas que são extremamente atuais, uma vez que o trabalho do ator passa constantemente por mudanças, mas conserva sua natureza evolutiva espiralada.

Nesse sentido, propomos compreender a encenação como um ato musical, passando a dar maior ênfase à estrutura sonorotemporal da cena e relativizando a perspectiva tradicional, que se apoiava principalmente no dado espacial, aliando os avanços tecnológicos aos estudos para desenvolvimento da arte do ator e capacitando-o para que seja o compositor de sua própria atuação.

Yedda Chaves em suas aulas ensinou que o trabalho do ator não se apoia na imitação de uma situação pelo número de detalhes, não é isso que dá autenticidade à cena. É necessária a utilização da imaginação conectada à ação. ${ }^{24}$

Nesse sentido, escreve: "se em Meyerhold os princípios reguladores da interpretação - amplo treinamento do aparato intelectual e físico através de estudos com a música, com a literatura, com a métrica, com os esportes, com a filosofia e psicologia - definem um conjunto de preceitos estéticos, éticos e filosóficos destinados a configurar "a nova arte do ator", em Bagdanov ${ }^{25}$ temos os princípios resgatando o aprendizado biomecânico do corpo-mente, experiência que injeta uma preciosa referência ao nosso conhecimento, a transmissão viva" ${ }^{26}$.

\footnotetext{
${ }^{23}$ PICON-VALLIN, Béatrice. 2006. op. cit. p. 28.

24 (informação verbal) Aulas ministradas no curso de pós-graduação CAC - ECA - USP na disciplina: V. Meyerhold e o Ator do Futuro, aplicação das neurociências, 1ㅇsemestre de 2010.

${ }^{25}$ Discípulo de Meyerhold, com quem a Professora Dra. Yedda Chaves trabalhou em seus estudos.

${ }^{26}$ CHAVES, Yedda Carvalho. A Biomecânica como princípio constitutivo da arte do Ator. Dissertação de mestrado do Centro de Artes Cênicas da Escola de Comunicação e Artes da Universidade de São Paulo (CAC/ECA/USP), São Paulo, 2001, p. 156
} 
Meyerhold inaugura um importante precedente para a composição cênica, principalmente no trabalho do ator, quando busca dar a ele autonomia, capacitando-o a ser o elo friccional das diversas linguagens que passam a integrar seu trabalho.

A velocidade das informações e das transformações que configuram nosso tempo trazem, a este ator, mais possibilidades de instrumentalização e, consequentemente, maiores exigências e necessidades tanto em sua formação, quanto em sua expressão poética. Nem sempre instrumentalizar-se significa ampliar seu repertório, já que o acúmulo de informações nem sempre se transborda em experiência ${ }^{27}$, é preciso que o ator abra espaços em sua vida para que ela ocorra.

Bondia (2002) nos alerta para o fato de que só é possível viver uma experiência na pausa, na suspensão do atropelo dos movimentos da rotina cotidiana. Não é sujeito da experiência aquele que propõe, impõe, opõe, põe. Para vivê-la é preciso se expor. Já que para ele a experiência é o que nos passa, o que nos acontece, o que nos toca. Não o que se passa, não o que acontece, ou o que toca. Então, realizar muitas coisas ao mesmo tempo, ou apenas o fato de querer dar conta delas, impede que elas realmente nos aconteçam. É como se tudo estivesse organizado para que nada nos aconteça. Isso também se dá no campo educacional e, portanto, na formação do ator.

"Nessa lógica de destruição generalizada da experiência, estou cada vez mais convencido de que os aparatos educacionais também funcionam cada vez mais no sentido de tornar impossível que alguma coisa nos aconteça. Não somente, como já disse, pelo funcionamento perverso e generalizado do par informação/opinião, mas também pela velocidade. Cada vez estamos mais tempo na escola (e a universidade e os cursos de formação do professorado são parte da escola), mas cada vez temos menos tempo. Esse sujeito da formação permanente e acelerada, da constante atualização, da reciclagem sem

\footnotetext{
${ }^{27}$ Atribuímos à palavra "experiência" o sentido cunhado por Lorge Larossa Bondia em seu texto "Notas sobre a experiência e o saber da experiência" xxxxxxxxxx
} 
fim, é um sujeito que usa o tempo como um valor ou como uma mercadoria, um sujeito que não pode perder tempo, que tem sempre de aproveitar o tempo, que não pode protelar qualquer coisa, que tem de seguir o passo veloz do que se passa, que não pode ficar para trás, por isso mesmo, por essa obsessão por seguir o curso acelerado do tempo, este sujeito já não tem tempo. E na escola o currículo se organiza em pacotes cada vez mais numerosos e cada vez mais curtos. Com isso, também em educação estamos sempre acelerados e nada nos acontece"28

Não se trata de aceitar como verdade suprema a liquefação do mundo, mas em pensar elementos para a formação de um ator emancipado, que seja capaz de compor sua atuação, levando em conta a liquidez de seu tempo e tudo que a alimenta ou que é gerado por ela.

Principalmente pensar uma formação que abra espaços para a experiência. Uma experiência multidimensional, global e que considere a complexidade do humano em formação, da arte em si e do mundo onde estão contextualizadas a expressão artística e a própria formação desse ator.

${ }^{28}$ BONDIA, J. L.. Notas sobre a experiência e o saber da experiência. In Revista Brasileira de educação. N. 19. São Paulo: ANPEd - Associação Nacional de Pós-Graduação e Pesquisa em Educação, 2002. p. 23 


\subsection{Uma pedagogia para a formação do ator}

O trabalho do ator, no teatro, é intrigante por vários aspectos, mas principalmente pelo fato de ser ele o elo físico presentificado entre a obra de arte e o público. Qualquer outra arte pode existir pela mera reprodução utilizando-se da tecnologia, mas não o teatro. É no ator que se concretiza a experiência teatral, ainda que o público receba estímulos de todos os elementos que compõem a cena.

Por sermos múltiplos, como consequência de sermos viventes, nossas experiências também se dão na multiplicidade, nossa percepção não separa, segrega e isola para depois juntar as partes e formar compreensões quer sejam elas racionais, afetivas ou pulsantes.

No entanto, a formação do ator, como qualquer outra no mundo ocidental em geral, se dá como se fosse necessário aprender as partes para, num momento posterior, realizar algum esforço no sentido de coordenálas até que possam, juntadas, significar algo. Isso se dá, em grande parte, pela supervalorização da ciência e da técnica, resultando num pensamento racionalista.

"Decorrente dessa concepção está a crença metodológica pela qual se deve partir do simples até ao complexo, do indiferenciado até o diferenciado e nítido. Para que algo adquira identidade perceptiva, o pensamento deve partir das impressões e sensações difusas, encaminhando-as para um grau crescente de especificidade e de destinação sensorial: o tato, a audição, a visão, o paladar e o olfato. Uma vez diferenciados, a unificação dos sentidos dá-se pela associação e síntese dos atributos comuns pertencentes ou ao objeto (doutrina das informações equivalentes) ou ao sujeito (doutrina dos atributos sensoriais análogos). ${ }^{29}$

A partir da ideia do ser sensível, Yara Caznok nos ajuda a concluir que aquilo que é percebido por um dos sentidos humanos, não é uma experiência apenas dele, mas que há coexistência e comunhão, pois há uma visão, uma escuta, um olhar, um inspirar e um tatear sobre o mundo. "A

${ }^{29}$ CAZNOK, Yara Borges. Música: entre o audível e o visível. 2 ed. São Paulo: Editora UNESP; Rio de Janeiro: Funarte, 2008, p. 125-126 
sensação e o sentir são uma modalidade da existência e não podem, por isso, se separar do mundo."30

Não se trata apenas de sinestesia. Mas do fato de que pensamentos objetivos costumam ignorar a integralidade das percepções. Nossa atuação resulta das nossas percepções do mundo em constante complementaridade e conflito. Assim, o trabalho do ator deve considerá-lo em suas multiplicidades pessoal, social, cultural, histórica e econômica, por exemplo.

Ignorar isso produziu, nas últimas décadas, mais especialização fechada e fez com que buscássemos respostas ao trabalho do ator em segmentos daquilo que se percebe junto (porque foi "tecido junto"). Fez com que surgissem pensamentos teóricos e práticos que percebem o ator como ser fragmentado e isolado de seu viver, segmentando os saberes a fim de revelar detalhes dessa ou daquela parcela da técnica a ser utilizada, retirando-nos a compreensão do todo.

$\mathrm{O}$ ator, por receber uma formação disjuntiva e que ignora a ideia de multiplicidade e a liquidez do nosso tempo ${ }^{31}$, fica refém de fórmulas e mecanismos que acabam por criar na "mimese" um padrão para sua formação, produzindo um teatro que aproxima demasiadamente a atuação de um naturalismo, que atende bem a atuação na televisão e no cinema, mas que não fazem mais sentido enquanto reprodução da vida na arte teatral, inclusive porque os outros dois veículos o fazem com maior perfeição. Ainda quando dentro do naturalismo, precisa compreendê-lo tão a fundo, a ponto de não cair na imitação banal. Ao ator, no teatro, caberia exatamente metamorfosear a realidade em crítica.

A própria constituição do teatro é um tanto contraditória. Quando fundado na mimese faz da ação uma ilusão e, por vezes, da ilusão uma ação. O texto teatral, mesmo quando considerado roteiro de ações, conta algo que tende a ser duradouro, mas a cena (ou a encenação) tende a ser efêmera, pois é a leitura de um momento, representado. A união entre texto e

\footnotetext{
${ }^{30}$ CAZNOK, Y. B. op cit. P. 127

${ }^{31}$ Quando falamos da formação do ator, neste trabalho, normalmente nos referimos à formação ocidental em cursos técnicos e graduações, que segmenta o aprendizado em voz, corpo, interpretação, teoria, canto, dança entre outras.
} 
cena, assim, parece antinatural, não se realiza a não ser a partir de convenções.

Se o teatro é convenção e o papel do ator está em constante transformação nesse contexto, é necessário um teatro que não imite a vida, já que esta apenas reforça o status quo sem colocá-lo em questão, sem possibilitar um olhar distanciado e crítico em relação a ele. E para este teatro são necessários atores capazes de compor seu trabalho para além da imitação e que deem conta das transformações iniciadas no século $X X$, que clamam atuais agora pela urgência de que se diga algo para além do óbvio, além de darem conta da multiplicidade da vida e do próprio homem.

Neste sentido dá-se nossa total adesão à visão artísticopedagógica de Meyerhold. A professora Yedda, em sua dissertação, comenta:

"quando Meyerhold fala de realismo, ele distingue entre o realismo que imita as situações do cotidiano e o realismo que aporta novas visões ao mesmo. O primeiro não modifica a vida, ao máximo a documenta como faz a fotografia jornalística; o segundo, aspirado por Meyerhold, através de técnicas de composição, enriquece as reservas de conhecimento por via da apercepção."32

A busca de Meyerhold se deu nesse sentido. Em seu trabalho para um maior distanciamento do naturalismo, operou em algumas bases para a atuação, dentre elas o "paradoxo", conquistado a partir do grotesco e compreendido, neste sentido, como o diálogo dos opostos, que é tomado aqui enquanto arte para a composição do ator. O grotesco para Meyerhold não é somente um estilo, ele o considera um método. É um caminho para a realização de uma transformação intencional de dados naturais. Aprofunda a vida cotidiana para além do que normalmente vemos, para o inexplorado.

No entanto, age sempre na polifonia ${ }^{33}$, não só sob o ponto de vista do ator, mas de toda composição cênica. Quando busca o

\footnotetext{
${ }^{32}$ CHAVES. 2001. op. cit. p. 34

33 Polifonia vem do grego e significa muitas vozes, pluralidade de sons. Contrapõe-se à ideia de uníssono. Na música, designa a situação com várias melodias que se desenvolvem independentemente, podendo ter várias partes simultâneas e harmônicas. As partes são independentes, mas de igual importância. Embora a música polifônica seja primordialmente vocal, o termo também pode aplicar-se a obras instrumentais. Na literatura, tem como principal propriedade a diversidade de vozes
} 
estranhamento, não o faz para se distanciar do cotidiano, contrariamente busca aprofundar o cotidiano. É um olhar no sentido de lupa, de se apropriar do detalhe, que permite a composição do grotesco. Para Meyerhold, no homem o exterior e o interior são sempre ligados, mas é a expressão formal que traduz isso em cena.

Um ator que possa trabalhar a técnica, mas tenha autonomia para alcançar a poética. Que compreenda o treino ou estudo como o lugar do repertório a ser encarnado, para que assim possa criar arte com seu corpo a partir das bases propostas ao seu trabalho. Mas fundamentalmente um ator emancipado a ser compositor de suas ações cênicas com consciência de seu papel social, mantendo princípios éticos e estéticos.

\section{É assim porque todo o teatro se transforma. As} tecnologias agregadas à cena, notadamente na iluminação, sonoplastia, multimeios, cenografia e figurino ou design da aparência ${ }^{34}$, compõem dramaturgias em uníssono ou polifonia com as dramaturgias do texto, do diretor ou encenador e do ator.

"A prática ultrapassou novamente a teoria. Eu não falo somente da contestação do encenador tirano e castrador, formulada com força e ingenuidade por alguns atores, por volta de 1968, se tornando palavra de ordem, moda. Uma outra transformação, mais ampla e mais profunda, está afetando o teatro. $O$ advento do encenador e a consideração da representação como um lugar de significação (não como uma tradução ou decoração de um texto) constituíram, sem dúvida, apenas uma primeira fase. Constatamos hoje uma emancipação gradual dos elementos da representação teatral e observamos uma mudança estrutural: a renúncia à unidade orgânica

\footnotetext{
controversas no interior de um texto. Conforme a tese do linguista russo Mikhail Bakhtin, este conceito se caracteriza pela existência de outras obras na organização interna de um discurso, as quais certamente Ihe influenciaram e alimentaram.

${ }^{34}$ Expressão cunhada por Adriana Vaz Ramos, em sua tese de doutorado $O$ design de aparência de atores e a sua comunicação em cena, pela PUC/SP em 2008, que refere-se, mais especificamente, aos relacionamentos expressivos entre cores, formas, volumes e linhas que materializam os figurinos, as maquiagens, os penteados e os adereços, visando traduzir, em matéria plástica sensível, a caracterização de um ator numa cena espetacular. A expressão figurino ficaria ligada mais às relações decorrentes de um desenho mimético e referencial, que antecede o espetáculo em que se insere o ator; como é o caso dos figurinos que retratam determinada época, por exemplo.
} 
ordenada a priori e o reconhecimento do fato teatral enquanto polifonia significante, aberta para o espectador." ${ }^{35}$

E aí está o motivo de qualquer teatro, o público. Se não para outrem, não há teatro! Mas acompanhando o percurso de todo o aparato teatral, o público também é outro e com outras necessidades. Daí preferirmos a palavra "público" à palavra "espectador". Esta pessoa, vivendo no século da interatividade e da conectividade, quando vai ao teatro não espera apenas assistir, ela própria é parte da estrutura, que só se completa se e quando friccionada a ela.

A nosso ver, a musicalidade de um movimento é capaz de revelar os elos que constituem a profundidade, a brevidade e os contrastes de cada um. Considerando a multiplicidade e individualidade humana, entendemos que a polifonia traduz, em certa medida, a possibilidade de coexistência e fricção dos diversos lados da pessoa e também das diversas pessoas em um coletivo, não tanto pela harmonização, que nem sempre é necessária, mas principalmente pelo resgate da essência, tanto do indivíduo quanto do grupo, como tal.

Meyerhold entende que o teatro revela sempre uma divergência entre os elementos humanos que o compõem: autor, encenador, ator, figurinista, cenógrafo, músicos e técnicos de palco não conseguem chegar a fundir-se na sua obra comum. Então propõe a esses criadores, que são o próprio fundamento do teatro, se constituírem apenas um, com a condição de abordarem o trabalho no espírito do que havia feito no TeatroEstúdio quando dos ensaios de La Mort de Tintagiles ${ }^{36}$, que culminou na ideia do $4^{\circ}$ criador e do teatro de Convenção que abordaremos adiante (item 3.3), a partir das quais busca estabelecer inúmeras conexões utilizando-se da musicalidade no trabalho do ator.

A musicalidade pode ser libertadora para o trabalho mimético de pura reprodução, sem reflexão, sem incorporação e sem voz. O

\footnotetext{
${ }^{35}$ DORT, Bernard. A representação emancipada. Revista Sala Preta, vol. 13. no1, jun 2013, p . 57

${ }^{36}$ Foi uma das primeiras encenações de Meyerhold, em 1905, no Teatro Estúdio, em Moscou, onde provocou o diálogo entre todos os participantes, administrando as friç̧ões, para tentar a fusão das ideias entre texto, encenador, atores e outros profissionais.
} 
ator não é um aplicador de técnicas e embora possa fazer isso muito bem, ele deve dominá-las, não ser escravo delas.

"O ser humano não só vive de racionalidade e de técnica; ele se desgasta, se entrega, se dedica a danças, transes, mitos, magias, ritos; crê nas virtudes do sacrifício, viveu frequentemente para preparar sua outra vida além da morte. Por toda parte, uma atividade técnica, prática, intelectual testemunha a inteligência empírico-racional; em toda parte, festas, cerimônias, cultos com suas possessões, exaltações, desperdícios, "consumismos", testemunham o Homo ludens, poeticus, consumans, imaginarius, demens. As atividades de jogo, de festas, de ritos não são apenas pausas antes de retomar a vida prática ou o trabalho; as crenças nos deuses e nas ideias não podem ser reduzidas a ilusões ou superstições: possuem raízes que mergulham nas profundezas antropológicas; referem-se ao ser humano em sua natureza. Há relação manifesta ou subterrânea entre o psiquismo, a afetividade, a magia, o mito, a religião. Existe ao mesmo tempo unidade e dualidade entre Homo faber, Homo ludens, Homo sapiens e Homo demens. E, no ser humano, o desenvolvimento do conhecimento racional-empírico-técnico jamais anulou o conhecimento simbólico, mítico, mágico ou poético."37

Tudo é "tecido junto" em nós e está presente a todo instante. Então, ao ator, cabe permitir a exposição dessa multiplicidade em arte a partir de si próprio. Não como algo esotérico, mas a partir da consciência de quem é em sentido global, de seu contexto, de sua multidimensionalidade e de sua complexidade. Em outras palavras, é preciso dedicação e estudo para que domine técnicas que possibilitem esses percursos.

Mas se alcançar a poética é o que pretendemos a partir da técnica, é fundamental a compreensão de que é necessário desenvolve-la de forma profunda, para instrumentalizar o ator (com o objetivo de ampliar seu repertório incorporado e não de promover a aquisição de um turbilhão de informações, das quais não dá conta), retirando dele a crença de que atuar é

${ }^{37}$ MORIN. 2001. op. cit. p. 66 
agir conforme as sensações do momento. Há uma gama enorme de atores e, mais espantosamente, de formadores de atores, inclinados a entender que a técnica retira a essência dionisíaca do aqui e agora, atributo da poética. Mas isso não procede.

Esses atores, em geral buscam sentir as emoções, mas acabam esquecendo que é ao público que devemos emocionar. A formação do ator deve olhar, portanto, de forma criteriosa para a psicologização, evitando a noção de que ator bom é aquele que "sente". Devemos trazer à formação desse ator uma preparação forte no sentido de instrumentalizá-lo a criar em cena as emoções, sem necessariamente trazê-las para si, mas dando vazão ao seu transbordar em arte a partir de suas ações.

"O 'ator da interioridade' só busca revelar seu estado de alma pessoal. Ele se recusa a obrigar sua vontade a dominar os procedimentos técnicos.

$\mathrm{O}$ 'ator da interioridade' orgulha-se de ter dado à cena o brilho da improvisação. Ele pensa, ingênuo, que suas improvisações têm algo em comum com a antiga comédia italiana. $O$ 'ator da interioridade' não sabe que os intérpretes da Commedia dell'Arte só desenvolviam suas improvisações a partir do roteiro gerado por sua técnica refinada, e não de outra maneira. $\mathrm{O}$ 'ator da interioridade' recusa categoricamente toda técnica - 'a técnica entrava a liberdade de criação' - é o que ele sempre diz. Para ele só tem valor o momento da criação inconsciente fundamentado na emoção. Se chega esse momento é o sucesso; se não, o fracasso.

Quer dizer que um jogo calculado dificulta que 0 ator manifeste a emoção? Todos os gestos do homem que agia junto ao altar de Dionísio eram movimentos plásticos. As emoções o incendiavam, parece, irresistivelmente; o fogo do altar engendrava nele um êxtase profundo. Entretanto, o ritual consagrado ao deus do vinho prescrevia antecipadamente métrica e ritmo precisos, procedimentos técnicos determinados para as transições e os gestos. Eis um exemplo no qual o jogo calculado do ator não impedia a manifestação de seu temperamento. $\mathrm{O}$ dançarino grego, embora tivesse que observar toda 
uma série de regras tradicionais, não deixava de introduzir em sua dança todas as invenções pessoais que desejasse." 38

Desta maneira, propor uma formação do ator onde friccionem a racionalidade, a afetividade e a pulsão, pautada na técnica que transbordará em poética é um desafio a ser afinado ao longo dos anos, mas que urge ser tratado desde agora.

Pensando que "a afinação pode ser pensada como convergência de dois estados complementares: o estado de escuta e o estado de música" ${ }^{39}$, propomos desenvolver neste trabalho bases para que possamos aguçar ambos, sempre de forma múltipla e global (no sentido de amplo, de todo, de holos e não no sentido de globalizante), sem a pretensão de darmos conta de sua realização.

"A escuta cultiva a qualidade da observação, convocando-se os sentidos - visão, audição, olfato, paladar e tato -, no sentido de si, do outro e do espaço. Por um lado, coloca-se como condição necessária para o desenvolvimento de práticas corporais e vocais, que promovam o equilíbrio tônico e impulsionem sua expansão. Por outro lado, expõe o ator no espaço, em suas dimensões do eu, no contato com seu intimo reduto, da pessoa na relação com o outro, e do cidadão nas conexões com o espaço: vetores que migram do campo privado ao campo público. A voz do outro me toca assim como minha voz toca o outro. A compreensão dessa troca de toques se faz com o cultivo e a construção de uma escuta, fruto de desejo e de escolha.

O estado de música busca a integração das pulsões corporais e vocais, pelos ritmos das palavras e dos cantos, harmonizando-se os movimentos da voz e do corpo. (...) A voz porta as marcas da história do sujeito, frutos de sua memória pessoal e cultural impregnadas de desejo, poder que o impulsiona para o desconhecido. Por meio do ritmo, o estado de música catalisa essas polaridades, para acionar a centelha da presença plena do corpo da voz do ator. Música cantada,

\footnotetext{
${ }^{38}$ MEYERHOLD. V. E. Do Teatro. Apud THAIS, Maria. Na cena do Dr. Dapertuto: poética e pedagogia em V. E. Meyerhold: 1911 à 1916. São Paulo: Perspectiva: Fapesp, 2009, p. 333

39 MARTINS, J. B. Dal Farra. Percusos Poéticos da Voz. Revista Sala Preta. N.7. Dossiê Voz. São Paulo: CAC-ECA-USP, 2007.
} 
coletiva, ponto de explosão do rito teatro, o estado de música configura-se como estado poético de criação teatral. ${ }^{.40}$

Se considerarmos ambos os estados numa forma mais ampla, pensando na formação do ator, conservando as definições dadas, fica evidente que é essencial ao ator desenvolver a percepção de uma musicalidade que the permita aguçar tais possibilidades cênicas e de investigação.

São princípios do trabalho do ator a partir da musicalidade, enquanto gatilhos para o trabalho, instaurando alguns focos para a musicalidade transbordar. $\mathrm{O}$ estado de escuta conecta esse ator ao outro e ao espaço, enquanto o estado de música desperta a presença e a criatividade.

Esta é uma tarefa complexa. Não precisamos de fórmulas ou cartilhas, mas precisamos despertar no ator a sensibilidade para alguns elementos fundamentais em seu trabalho, como por exemplo, o humano, o espaço, a criação teatral. O humano constitui a ele próprio, todas as outras pessoas envolvidas em seu trabalho e o público com quem estabelecerá relações. O espaço, por mais variável e inusitado que seja, sempre existirá e exigirá deste ator um caminho de apropriação e diálogo. A criação teatral é o motivo de todo o resto, ainda que fique à deriva em alguns casos, necessita de uma faísca potente, geradora do fenômeno artístico.

"Meyerhold não perseguia um 'modo de atuar', mas um teatro que reencontrasse sua essência dinâmica, ou seja que estabelecesse, a cada obra, os procedimentos da encenação. $O$ teatro meyerholdiano tomou o ator como símbolo da cena e propôs que a técnica fosse um instrumento contra o procedimento da ilusão. Suas reflexões sobre 0 tema apresentam uma abordagem complexa do fazer teatral, e não se reduzem apenas à realização de uma linguagem cênica própria, ainda

${ }^{40}$ MARTINS. 2007. op. cit. 
que sempre culminem nela, tecendo um diálogo provocativo com a produção teatral do seu tempo." ${ }^{41}$

O unitas multiplex, considerado em seu contexto e sob o ponto de vista das relações e conexões que o ator estabelece consigo, com o outro e com o espaço, pode ser objeto de uma formação não-disjuntiva, que estimula a criação teatral. A musicalidade vem como proposta de um percurso que respeite todo esse material.

Cremos ser possível uma interpretação de qualidade pela qual o ator, ao compor a personagem, é capaz de aliar seus repertórios técnico e sensível para voz e corpo, permitindo a libertação de sua musicalidade em cena, estabelecendo uma criação com consciência de ritmo, intensidade e sons, colocando o ator em fricção com seu tempo e com a arte, de modo a não cristalizar procedimentos.

${ }^{41}$ THAIS, Maria. Na Cena do Dr. Dapertuto: poética e pedagogia em V. E. Meyerhold: 1911 à 1916. São Paulo: Perspectiva: Fapesp, 2009, p. 61 


\section{Musicalidades}

A música constitui sempre o roteiro dos movimentos, esteja ela presente, realmente, no teatro ou apenas suposta, cantarolada pelo ator que age em cena. Vsévolod Meyerhold ${ }^{42}$

\subsection{De que música estamos falando?}

Todos entendemos, de alguma forma, o que é música e quais seus possíveis efeitos sobre os seres vivos. Não é de hoje, aliás, que presenciamos pesquisas, experiências e experimentações que envolvem música e plantas, música e animais, música e homens, desenvolvendo-se ao ponto de chegarmos à ciência chamada musicoterapia, que trabalha os efeitos da música no homem e na humanidade.

O fascínio que a música exerce é primordial, não apenas enquanto sonoridade, mas também com elemento catalisador de nossos anseios e projeções. Embora seja encontrada em cachoeiras, pássaros, golfinhos e entre tantos outros lugares da natureza, é inegável que ela também representa uma prática cultural e humana.

A própria formação do universo e da Terra podem ser observadas a partir de princípios musicais, dentre tantos outros. O simples movimento de expansão e contração das galáxias, gerando ondulação, traz a ideia de presença e ausência e, portanto, de música.

Por ser um elo ancestral do homem com sua própria ancestralidade a música está presente desde as primeiras manifestações sagradas. Dentre os estudiosos da música, Marius Schneider colheu, nas mais diferentes tradições, informações sobre o lastro mítico do mundo modal. Constata que na origem do universo, o "deus" (ou "deuses") se apresenta e se cria a partir do som, na execução de tambores ou outros instrumentos, ou ainda a partir de imagens que remetam a sons. Ao falar das pesquisas de

${ }^{42}$ Apud PICON-VALLI. 2006. op. cit. p. 49 
Schneider e das religiões que se ligam aos seus deuses a partir da música, Winsik (1989) escreve:

"No hinduísmo, que é como já disse, uma religião intrinsecamente musical, toda constituída em torno do poder da voz e da relevância da respiração, atribui-se a proferir a sílaba sagrada OUM (ou $A U M$ ), o poder de ressoar a gênese do mundo. O sopro sagrado de Atman (que consiste no próprio deus) 'é simbolizado por um pássaro cuja cauda corresponde ao som da consoante $m$, enquanto a vogal a constitui a asa direita e o $u$ a asa esquerda'. A música ocupa um lugar entre as trevas e a luminosidade da aurora, entre o silêncio e a fala, o lugar dos sonhos, 'entre a obscuridade da vida inconsciente e a clareza das representações intelectuais'.,"43

A música está em tudo e é constitutiva desse todo, uma vez que é inerente à nossa existência a questão do tempo, do ritmo e das alturas dos sons e das coisas. Assim, música não se restringe aos sons concatenados que ouvimos, mas a toda produção sonora universal. A ideia de ruído, mais debatida adiante e a dos sons à nossa volta está fundada em princípios musicais.

Essa paisagem sonora do mundo muda constantemente, mas no último século passou por alterações significativas, trazendo para o ouvido humano um ambiente acústico radicalmente diverso de qualquer outro que ele conhecesse.

A sonoridade com a qual convivemos na rua, na escola, no trabalho, enfim, na vida, além de afetar nossa relação com o mundo, está permeada de contrações e expansões, tempos, ritmos e alturas, portanto, são fontes incessantes de música.

Então, que música é essa?

Talvez não seja possível encontrar uma definição de música que a contemple em sua amplitude. Mais do que qualquer outra manifestação humana, a música contém e manipula o som e o organiza no tempo. Talvez por essa razão ela esteja sempre fugindo a qualquer definição, pois ao buscá-la, a música já se modificou, já evoluiu. E esse jogo do tempo é

${ }^{43}$ WISNIK, José Miguel. O som e o sentido. São Paulo: Companhia das Letras, 1989, p. 38 
simultaneamente físico e emocional. Como "arte do efêmero", a música não pode ser completamente conhecida e por isso é tão difícil enquadrá-la em um conceito simples.

Os estudiosos da ciência musical, mais recentemente, definem música como "uma organização de sons com a intenção de ser ouvida" 44 . Por "sons" podemos entender o ritmo e as alturas (que podem formar melodias) em relações estabelecidas com o silêncio. Assim, nos termos em que nos propomos a abordar a música neste trabalho, são bases de uma composição musical: uma organização, ritmos, melodias, silêncios, a intenção e a escuta.

Compreender essas bases é importante para o trabalho de composição do ator e sendo este o trabalho capaz de tornar esse ator "musical", é fundamental que passemos, ainda que rapidamente, pela apreciação destes elementos. Dois possuem uma explicação mais uniforme dentro e fora do universo musical: o ritmo é a sequência organizada de apoios e a altura é a quantidade de vibrações por segundo de um corpo sonoro. Obviamente, nas artes cênicas agregamos elementos a estes conceitos, mas é certo que eles permanecem.

A melodia, por sua vez, pode ser considerada a sequencia organizada dos sons. Aí entramos no universo dos sons melódicos, que se constituem em boa parte de vibrações regulares, ou seja, alturas mais ou menos definidas medidas em Herz. Todo instrumento possui um percentual de ruído em seu som. O violino tem a fricção do arco com as cordas, e essa friç̧ão é um ruído formado de um mix de vibrações irregulares. O que sobressai, no entanto, é o som formado de vibrações regulares, ou seja, uma altura definida, mensurável e o principal, perceptível por nós como constante e, na maioria das vezes, mais confortável.

A disposição musical pode ainda se dar a partir da harmonia, quando ocorrer em simultaneidade, quanto ao sentido de organização temporal que possui. Harmonia normalmente trabalha com as

\footnotetext{
${ }^{44}$ SCHAFER, Murray. O Ouvido Pensante. Trad. Maris Trench de O. Fonterrada, Magda R. Gomes da Silva, Maria Lucia Pascoal. São Paulo: Fundação Editora da UNESP, 1991, p.35
} 
sonoridades resultantes da sobreposição de diferentes notas, o ritmo e a melodia não necessariamente.

Organização é uma expressão que comporta infinitas possibilidades de explicação. Ainda que não definamos a palavra, corremos o risco de desprezar entendimentos sobre sua importante função. No entanto é necessário entender de que tipo de organização pode tratar a experiência musical.

É a música quem organiza o som no tempo, propagando no espaço o resultado sonoro desta combinação. Portanto, é a partir da organização e não dos sons em si, que podemos perceber e ser atingidos pela reverberação espacial da música. Em outras palavras, é a organização dos sons e de suas relações com o silêncio, e não os sons e silêncios em si, mas o modo como são agrupados a partir das escolhas em utilizar suas propriedades $^{45}$, que produz música.

Podemos dizer, então, que a organização, independentemente de qual seja ela em cada situação em que se apresente como práxis, é inerente à música e que esta é determinada a partir daquela.

A outra base constitutiva da música é o silêncio. O silêncio seria a ausência de sons, como o preto para as cores. No entanto, esta é uma convenção, uma vez que seria impossível retirar todo o som à nossa volta, nas condições normais do cotidiano. Para Schafer ${ }^{46}$, o silêncio é um recipiente dentro do qual é colocado um evento musical, protegendo-o contra o ruído, possibilitando-o enquanto acontecimento sensível. Para ele "o silêncio torna-se cada vez mais valioso, na medida em que nós o perdemos para vários tipos de ruído: sons industriais, carros esportes, rádios transistores, etc.". E completa, "o silêncio é a característica mais cheia de possibilidades da música", uma vez que tudo pode acontecer para quebrá-lo.

Em nossos dias o ruído faz parte do ambiente sonoro natural, uma vez que ficar em silêncio significa conviver ou atentar-se aos sons

\footnotetext{
${ }^{45}$ Neste sentido, engloba toda combinação de elementos sonoros destinados a serem percebidos pela audição, o que inclui variações nas características do som (altura, duração, intensidade e timbre) que podem ocorrer sequencialmente ou simultaneamente (ritmo, melodia e harmonia).

${ }^{46}$ Ibidem. op. cit. p. 71
} 
da nossa vida cada vez mais líquida ${ }^{47}$. Sendo o silêncio uma convenção, já que sua existência foi questionada de forma veemente por John $\operatorname{Cage}^{48}$, e sendo ele o ponto onde se apoia e onde se contrapõe o som, podemos imaginá-lo como o "espaço dos acontecimentos musicais".

Vivemos num ambiente sônico totalmente diferente daquele em que viveram nossos avós e, pela natureza cíclica espiral da história, a música do mundo está em constante mutação. O que era ruído ontem, pode ser música hoje e vice-versa. Assim, preferimos entender aqui como ruído, o indesejável; aquele som que interfere na experiência sonora, destruindo-a ou limitando-a; o que não queremos ouvir. Desta forma é a seleção dos sons que faz com que os demais sons sejam ou não ruídos.

Retomando os elementos que constituem a base musical, nos restam dois: Intenção e Escuta.

Aceitando que música é a organização de sons com a intenção de ser ouvida, podemos compreender a ideia de que tudo a nossa volta pode ser música, desde que a coloquemos neste lugar. "Quando John Cage abre a porta da sala de concerto e encoraja os ruídos a atravessar suas composições $^{49}$, ele ventila a arte da música com conceitos novos e aparentemente sem forma" 50 . Em seguida o músico afirma: "música é sons, sons a nossa volta, quer estejamos dentro ou fora das salas de concerto" ${ }^{\prime \prime}$.

Deste modo a intenção é o primeiro gesto no sentido da constituição de uma linguagem. Se pretendo fechar os olhos por 30 segundos e ouvir a música do ambiente sônico em que me encontro num dado momento, elegi o que antes poderia ser considerado ruído, como música.

No dicionário, intenção é vontade, desejo, propósito, plano. Portanto, é essa habilidade em permitir a um fenômeno exterior ganhar

\footnotetext{
${ }^{47}$ Referência ao termo cunhado por Zygmutn Bauman, na obra Tempos Líquidos já citada

48 John Cage realizou uma experiência numa câmara à prova de som (anecoica), onde ouviu um som grave, que atribuiu à sua circulação sanguínea, e um agudo, atribuído ao funcionamento do seu sistema nervoso. (CAGE, John. De segunda a um ano. Tradução Rogério Duprat. São Paulo: Hucitec, 1985, p. XIV)

${ }^{49}$ Refere-se à obra 4'33", na qual o músico senta-se a frente do piano e executa 3 movimentos sem extrais qualquer som do instrumento, cronometrando o tempo no relógio e instigando a todos que escutem os sons que sempre estão sendo produzidos, o ambiente sônico

${ }^{50}$ SCHAFER. 1991. op. cit, p. 120

${ }^{51}$ Idem ibidem
} 
caráter e vida próprias, elevando-o à categoria de linguagem musical (assim como podemos fazer na linguagem teatral), que instaura os primeiros elementos para sua concretização. Se eu quero, pode ser música!

Obviamente não iremos ignorar os outros elementos, sobre os quais estamos discorrendo neste trabalho, mas para Schafer hoje todos os sons pertencem a um campo contínuo de possibilidades, dentro do domínio da música.

"Eis a nova orquestra: o universo sônico!

E os novos músicos: qualquer um e qualquer coisa que soe! $!^{52}$

A paisagem sonora é um elemento fundamental na compreensão da música e da musicalidade. Se atualmente ouve-se mais música por meio de reprodução eletroacústica que na sua forma natural, isso modifica toda compreensão, execução e ensino musical. Se meu ouvido está mais habituado a buzinas de carros, barulhos de trens, sirenes, vozes altas nas ruas e aviões, minha escuta é diferente daquela dos séculos XVIII, XIX e $\mathrm{XX}$, onde as paisagens sonoras eram compostas por outros elementos.

É preciso sempre considerar esse caráter mutável dos conceitos, pois os utilizamos no presente. Ao considerarmos os rastros deixados por aqueles que já se valeram deles, somos capazes de alcançar um percurso que nos permite avançar nas conexões possíveis a partir deles. Além disso, é sempre importante contextualizar. Se a música, como a sociedade, evolui, talvez o mais "natural" hoje seja a reprodução eletroacústica.

Finalmente, sobre a escuta, Pierre Schaeffer ${ }^{53}$ elenca quatro possibilidades para a escuta: escutar, ouvir, compreender e entender. Essa classificação nos interessa aqui no sentido em que amplia a compreensão da ideia sobre a escuta, consequentemente ampliando a visão de música que embasará o trabalho do ator, passamos a explicar as quatro propostas dele para escuta, em suas palavras:

\footnotetext{
52 Idem ibidem, p. 121

${ }^{53}$ SCHAEFFER, Pierre. 1966. Op. cit. p. 89-110
} 
"Escutar: é aplicar o ouvido, interessar-se por. Eu me dirijo ativamente a alguém ou a alguma coisa que me é descrita ou assinalada por um som.

Ouvir: é perceber pelo ouvido. Por oposição a escutar, que corresponde à atitude mais ativa, o que ouço, é aquilo que me é dado na percepção.

Entender: retivemos o sentido etimológico: ter uma intenção. O que entendo é o que me é manifesto; é função dessa intenção.

Compreender: tomar consigo, está numa dupla relação com escutar e entender. Compreendo o que eu visava na minha escuta, graças ao que escolhi para entender. Mas reciprocamente o que eu já compreendi dirige a minha escuta, informa aquilo que eu entendo. ${ }^{54}$

A audição é um dos sentidos mais desprotegidos que possuímos. Fechamos olhos, boca e nariz ao percebermos algo desagradável a eles, ou ainda não encostamos ou não pegamos determinadas coisas, mas para os ouvidos é diferente, o som já entrou quando nos damos conta que não desejaríamos te-lo ouvido. Isso colabora para que o ambiente sônico em que vivemos seja repleto de ruídos e que nossa escuta fique cada vez mais deficitária, já que não nos habituamos a selecionar os sons.

Ouvir, como exercer os outros sentidos, é inerente à existência do homem. Vivemos em um mundo que não cessa sua presença, então, não paramos nossa escuta (no sentido de ouvir). E esse mundo é tão visual, quanto tátil e sonoro. "Mas ouvir não é 'ser tocado por sons' que chegam ao meu ouvido sem atingir a minha consciência. Só em relação a ela é que o fundo sonoro adquire uma realidade. Adapto-me instintivamente ao elevar a voz, sem dar-me conta de que alterei o seu nível. ${ }^{55}$ Por outro lado a consciência das sonoridades, ainda quando fundos sonoros, se dá pela racionalidade (reflexão), o que nem sempre alcançamos quando estamos operando apenas no "ouvir".

\footnotetext{
54 Idem. op. cit. p. 91

${ }^{55}$ Idem ibidem
} 
Além disso, quando estamos escutando algo, sejam pessoas ou sons, aleatórios ou direcionados a nós, iniciamos as primeiras ligações com o objeto da nossa escuta, dispondo-nos a ouvir, ainda que apenas buscando identificação semântica. Não que escutar seja interessar-se pelo som, mas é estabelecer relações com a coisa escutada, que varia de acordo com inúmeros elementos que coexistem à escuta.

No entanto, se as relações estabelecidas com o que é escutado passam a ser organizadas em mim, racional ou afetivamente ${ }^{56}$, se passo a escolher as minhas escutas por preferências, há um aprofundamento dessa relação que remete para entender o que escuto. Em outras palavras, entender ocorre quando há um interesse em identificar os elementos circundantes daquilo que chegou ao meu ouvido, completando-o, ampliando-o ou superando-o. Esta etapa da escuta cria relações para além do que foi escutado, possibilitando sua apreciação, sua significação.

Já a compreensão vai além da significação, pois abstrai, compara, deduz e relaciona informações de fontes e naturezas diversas, indo para bem adiante do conteúdo imediato. Exige, portanto, uma ação mais direcionada de quem escuta.

A escuta talvez seja a mais necessária base de que imprescinde o homem e, da mesma forma, o ator. Principalmente se tomarmos o sentido da composição, a partir do conceito de música que escolhemos trabalhar, sem escuta não há música.

Finalmente, cabe ressaltar que a compreensão de música aqui extrapola a via musical ou cênica, mas impregna os poros da nossa existência, já que considerada a partir do cosmos, enquanto unidade macro, e da célula do corpo, enquanto unidade micro.

Também não se trata de investigar se há algo em comum com a música e o teatro. $O$ que nos interessam nessa relação não são as práticas artísticas por si, nem seus produtos, mas os aspectos que as concretizam no artista e no público.

\footnotetext{
${ }^{56}$ Esses conceitos serão trabalhados mais adiante a partir dos diálogos com Edgar Morin
} 
A esse respeito, João Frayze-Pereira afirma: "se há no mundo diversidade e unidade de diferentes modos de existência sensível e no nível do corpo diversidade e unidade dos sentidos, é porque há um só corpo, onde dois olhos veem, duas mãos tocam, onde visão e tato se articulam sobre um único mundo que vem ecoar nesse mesmo corpo." ${ }^{57}$

Então, é no corpo do artista (aqui o ator) que essa música principia, acontece e é capaz de tomar o espaço e o outro, ressonando. E isso é possível a partir da investigação da musicalidade no trabalho cênico.

${ }^{57}$ CAZNOK. 2008. op. cit. p. 12 


\subsection{A música e o movimento}

O movimento de qualquer coisa é capaz de fazer o ar vibrar. Quando essa vibração ocorre numa velocidade maior que dezesseis vezes por segundo, esse movimento se torna audível para nós. Portanto, o som que o ouvido humano reconhece tem origem num movimento. Se a música tem como uma de suas bases o som, podemos afirmar que música é movimento.

Tudo que envolve movimento produz som (audível ou não) e ele pode ser organizado segundo suas diferentes características (tempos, ritmos, altura, timbre etc.). Apenas para efeito de referência, se batermos na corda de um violino ou de uma guitarra, para o som que conhecemos como "dó central", os movimentos da corda se produzem na ordem de 261 vibrações por segundo.

A compreensão da música enquanto movimento e de que esse movimento se dá no espaço, durante algum tempo, é fundamental para o trabalho sobre a musicalidade.

Vamos lançar nossa atenção para uma das partes que compõem a música. O som é onda que decorre da vibração de um corpo qualquer, propagada no espaço e captada pelos ouvidos, que a transmitirão ao cérebro para construções cognitivas no campo da racionalidade, da afetividade ou ainda da pulsão.

"A onda sonora, vista como um microcosmo, contém sempre a partida e a contrapartida do movimento, num campo praticamente sincrônico (já que o ataque e o refluxo sucessivos da onda são a própria 'densificação' de um certo padrão de movimento, que se dá a ouvir através das camadas de ar). Não é a matéria do ar que caminha levando o som, mas sim um sinal de movimento que passa através da matéria, modificando-a e inscrevendo nela, de forma fugaz, o seu desenho." 58

${ }^{58}$ WISNIK. 2011. op. cit. p. 18 
Assim, não há som sem pausa, pois é o movimento de sua presença e sua ausência que produz a vibração capaz de materializá-lo. Não há som sem movimento, sendo o silêncio elemento fundamental para tornar audível o som. Daí que a musicalidade somente se dá a partir da oscilação recorrente entre as partes componentes de um todo.

Toda presença e ausência que formam o som capaz de produzir música se dá num corpo qualquer. Cada corpo possui em si características que afetam diretamente a qualidade do som que será produzido. Um jarro de barro é diferente de um cano de lata. Dois tubos de PVC também serão diferentes se possuírem diâmetros distintos. Assim, o corpo a partir do qual se pretende produzir som influencia diretamente a música que será produzida.

Então, se torna importante compreender dois elementos: o ritmo e as questões do instrumento sonoro, isto pois, no teatro, essa experiência musical de relações entre tempo e espaço se dão no corpo do ator.

"O homem é uma criatura antientrópica; é um organizador do acaso em ordem e tenta perceber padrões em todas as coisas. Em seu sentido mais amplo, o ritmo divide o todo em partes. ${ }^{.59}$

É uma necessidade humana organizar-se de qualquer forma que seja. Muito disso ocorre, pois em nós coexistem diversos ritmos, contínuos e descontínuos. O coração é um exemplo de ritmo contínuo, regular e dipódico ${ }^{60}$, que pode ir dos 50 aos 200 batimentos por minuto, variando somente no tempo o bombear para dentro e para fora. A respiração é outro ritmo regular que varia conforme o estado de relaxamento ou excitação.

As correspondências de ritmos da natureza com os ritmos produzidos pelo corpo humano estabelecem interessantes conexões

\footnotetext{
${ }^{59}$ SCHAFER, Murray. A Afinação do Mundo: uma exploração pioneira pela história passada e pelo atual estado do mais negligencido aspecto do nosso ambiente sonoro: a paisagem sonora. Trad. Marisa T. Fonterrada. São Paulo: Editora UNESP, 2001, p . 315

${ }^{60}$ Termo oriundo da literatura, que significa que a entonação é sempre bipartida (dois pés de verso).
} 
entre si. Muitos trabalhos a este respeito já foram desenvolvidos dando alguns exemplos, como a respiração em relaxamento e o quebra mar numa praia auxiliam na sensação de bem estar; ou ainda como a respiração em estado de excitação com sonoridades em ritmo muito acelerado pode aguçar os outros sentidos.

$\mathrm{Na}$ arte isso também ocorre. Schafer escreveu:

"Os ritmos de toda poesia e literatura declamada mantêm relação com o padrão respiratório. Quando a frase é longa e natural, espera-se um estilo respiratório relaxado; quando é irregular, ou saltitante, sugere um padrão respiratório irregular. Compare-se o estilo cheio de arrancos do verso do século $X X$ com os versos mais relaxados dos que o precederam. Alguma coisa aconteceu entre Pope e Pound, e isso, muito provavelmente, foi a acumulação de síncopes e contratempo na paisagem sonora. E o perceptível nervosismo dos versos de Pound começou depois que ele se mudou da vida rural da América, para a grande cidade de Londres. Do mesmo modo que o estilo coloquial humano é abreviado pela campainha do telefone, o verso contemporâneo traz as marcas do haver-se desviado dos estilhaços acústicos da vida moderna. São as buzinas dos carros que pontuam o verso moderno, e não os riachos murmurantes." ${ }^{\text {11 }}$

Deste modo, o ritmo, além de organizador do tempo em si como do próprio tempo no espaço, é também um fator importante no estabelecimento de conexões entre as pessoas e seus diversos estados psicofísicos; portanto é fundamental para o trabalho do ator o estudo sobre o ritmo em ambos aspectos.

Não é por outro motivo que todos os grandes mestres do teatro como Stanislavski, Meyerhold, Grotowisk, Barba, Mnouchkine, Martinez Corrêa entre tantos se debruçaram de alguma forma sobre a questão do ritmo no trabalho do ator e do encenador.

${ }^{61}$ SCHAFER. 2001, op. cit. p. 317 
No entanto, há um outro aspecto relevante que abordaremos também aqui: a corporeidade dessa música a ser produzida no teatro pelo ator está em seu próprio corpo e nas relações que este corpo estabelece com tudo que compõe a cena.

Pavis diz que "aplicados ao teatro, a ação e o corpo do ator se concebem como o amálgama de um espaço e de uma temporalidade e citando Merleau-Ponty - que o corpo não está apenas no espaço, ele é feito de espaço e, feito de tempo" ${ }^{62}$.

Compreendendo que a música é movimento que se dá no espaço, durante algum tempo e que possui qualidades que alteram sua percepção (como ritmo, duração e altura), podemos dizer que é fundamentalmente no corpo do ator que teremos a possibilidade de fazer com que a música seja percebida com todos os sentidos e não apenas com a audição e que é necessário que essa presença musical do ator se alastre para todo o espaço cênico, fazendo constantemente música, audível e não audível.

Agregar ao trabalho do ator a percepção da musicalidade em seus movimentos, em suas intenções e nas sonoridades que emana, fazendo-o incorporar as formas de propagação das ondas do movimento e as possibilidades de realizar um trabalho a partir dos ritmos, da duração e altura de sua presença é musicalizá-lo.

Esses são conceitos fundamentais, pois a organização do movimento no espaço diz respeito à musicalidade da cena e isso compõe a paisagem cênica, sendo o ator parte integrante, viva e geradora dela. Desta maneira, o ator é o centralizador do acontecimento teatral, onde se encontram tempo e espaço para expressar a cena.

O próprio Meyerhold já afirmava: "O ator não é o único elo entre o poeta e o público. Não é no drama musical, senão um dos meios de expressão, nem mais nem menos importante que os outros; o seu lugar é portanto entre esses meios. No entanto é graças ao ator, acima de tudo, que a música transpõe a medida de tempo em medida

${ }^{62}$ PAVIS, Patrice. Dicionário de Teatro. S. Paulo, Perspectiva, 1999. 
de espaço. Antes de ser posta em cena a música somente cria uma imagem ilusória do tempo; uma vez posta em cena, domina o espaço. Graças à mímica e aos movimentos do ator, regidos pelo desenho musical, o ilusório torna-se real; o que flutuava no tempo é materializado no espaço."63

${ }^{63}$ MEYERHOLD, Vsévolod. O Teatro Teatral. Trad. Redondo Junior. Lisboa: Ed. Arcádia, 1980, p. 82 


\subsection{Musicalidade}

Assim como não devemos separar as múltiplas partes de um indivíduo, porque foram "tecidas juntas" e qualquer fragmentação nos impede de olhá-lo como um todo e até mesmo de compreender as partes, pois deslocadas daquilo que lhes é elementar, não devemos separar música de musicalidade. No entanto, só é possível aprofundarmos nosso estudo se pudermos compreender esses conceitos em suas partes, mantendo a ideia de que são componentes que se complementam e se conflitam em constante coexistência.

Ainda assim não é uma tarefa fácil definir musicalidade. De um modo simplista, apenas como provocação inicial para pensarmos, podemos dizer que a música é a linguagem humana escolhida para expressar racionalmente a musicalidade, pois é capaz de converter em símbolos, com durações e alturas determinadas por uma escrita musical, as emoções humanas. Nesse sentido, musicalidade seria a faceta afetiva (e muitas vezes de pulsão) dessa música escrita.

No dicionário, musicalidade é descrita como: "s.f.: 1. Caráter do que é musical; 2. Dom, capacidade, especial sensibilidade para compor ou tocar música; 3. Cadência harmoniosa, ritmo; 4. Caráter acentuadamente musical de alguém ou de alguma coisa." ${ }^{64}$

Musicalidade é, portanto, um substantivo que traz em si a não-concretude física exterior ao humano, isto é, ela só se torna concreta no ser e a partir dele, como a dor, a saudade, a excitação, etc. Todos os estados que nos acometem são inerentes à nossa condição de humanos, mas só possuem existência a partir daquilo que sentimos de concreto em relação a eles. Desta forma, a musicalidade é um estado humano concreto porquanto sensível.

"A musicalidade é a essência do processo de tornar-se humano. Refletir sobre a musicalidade é uma ação que se volta para a mudança, abandono dos velhos hábitos enrijecidos, que levantaram

\footnotetext{
${ }^{64}$ FERRERIRA, Aurélio Buarque de Holanda. Pequeno Dicionário Brasileiro da Língua Portuguesa. 11 ed. 23 tiragem. Rio de Janeiro: Ed. Civilização Brasileira, 1982.
} 
barreiras a tantas pessoas. É adotar uma visão mais ampla da prática musical, que seja ao mesmo tempo um movimento de revitalização e atualização do pensamento musical..."”5

Não se trata apenas de uma aptidão para a música ou para sua percepção, mas da construção de uma atitude em relação ao mundo, de modo amplo, em relação ao tempo, ao espaço e às conexões estabelecidas e suas intensidades.

Música é movimento que se dá no espaço, durante algum tempo e que possui qualidades que alteram sua percepção. Compõem a musicalidade as conexões afetivas e instintivas que possibilitam e determinam essa movimentação. Mas a musicalidade é também fator essencial para a construção de sentidos, como já dissemos (item 2.1.).

Exatamente por isso a música transforma-se em consequência das mudanças de paradigmas socioculturais ou das necessidades político-econômicas, já que o humano inserido nesses contextos carrega consigo a musicalidade de seu tempo e de seu local. Daí a necessidade de serem compreendidas sempre em coexistência e fricção.

"A capacidade humana para perceber sons, reconhecer e retêlos na memória, assim como a capacidade para interpretar o que se ouve, atribuindo um significado, são capacidades muito precoces. As habilidades musicais, como qualquer outra aprendizagem, dependem de fatores internos, desde as condições físicas até aspectos físicos e motivacionais, e de fatores externos, como as possibilidades oferecidas pelo contexto sociocultural. Ao lado destes é preciso considerar que as habilidades musicais modificam-se muito ao longo da vida. (...) portanto, devem ser considerada numa perspectiva de desenvolvimento humano ao longo da vida." ${ }^{66}$

Se a vida apresenta-se como um processo contínuo e alternante entre as experiências propostas e as ocorridas, resultando em saberes acumulados ou descartados, em níveis racionais, afetivos e pulsantes, é necessário compreender que em cada etapa da formação do homem ele

\footnotetext{
${ }^{65}$ Anais do XV ENDIE - Encontro Nacional de Didática e Prática de Ensino - Convergências e tensões no campo da formação e do trabalho docente. Belo Horizonte, 2010, p . 1

${ }^{66}$ Idem ibidem, p. 4
} 
ressoa uma musicalidade (e que o mesmo acontece no processo de formação do ator).

Assim, é preciso uma escuta mais apurada sobre o corpo do ator. Este corpo entendido em sua forma múltipla, contemplando a estrutura física, a voz (elo entre a carne e a emoção), os laços emocionais e a base espiritual. Nesse sentido, o trabalho de Dalcroze olha para a música como elemento desse corpo.

"A dança era para os gregos um ritual religioso, incorporava ao mesmo tempo a arte e a filosofia. Mais tarde, a religião cristã destruiu essa unidade física e espiritual e induziu o homem a desprezar o corpo e a ver beleza somente no abstrato." 67

Retomando a conexão corpo-emoção e, portanto, os elos entre as inteligências racional, afetiva e pulsante, Dalcroze apoia-se na ideia de que o corpo é o mediador do conhecimento musical, pelo que chamou de sentido muscular. Em seu trabalho de consciência rítmica alcançada por movimentos, envolve o corpo como um todo, aproximando-se neste sentido de Stanislavski que, numa de suas propostas, parte do corpo em uma ação concreta para a construção de um conhecimento, que será constantemente reelaborado em fricções dos saberes racional e afetivo para reelaborar e ampliar as experiências desse corpo.

"Dalcroze (1865-1950) propôs um trabalho sistemático de educação musical, baseado no domínio do movimento corporal e na habilidade de escuta. Sua abordagem era totalmente nova para a época, que desconsiderava as oportunidades de se estabelecerem ligações entre a atividade cerebral e as sensações físicas, no caso o aprendizado da escuta musical.

(...)

A percepção da importância psicológica do movimento e sua relação com os aspectos afetivos e intelectuais levou Dalcroze a desenvolver seu Método de educação musical. Os instrumentos eram a voz cantada, o movimento corporal e o uso do espaço. Dalcroze procurava superar a dicotomia corpo-espírito, traço característico do

\footnotetext{
${ }^{67}$ ASLAN, Odete. $O$ ator no século XX: evolução técnica, problema da ética. Tradução: Raquel Araujo de Baptista Fuser, Fausto Fuser e J. Guisnburg. São Paulo, Perspectiva, 2008, p. 41
} 
século XIX, e propôs um ser humano integrado em si e consigo mesmo. Para isso desejava atuar entre os conceitos de liberdade e estrutura." ${ }^{68}$

É clara a relação dessa proposição com a ideia do unitas multiplex, essencialmente no sentido da busca da composição de um conhecimento que seja integralmente racional e integralmente afetivo, deixando espaço para as construções na pulsão/instinto. As experiências deixam de ser meramente intelectuais e passam por um processo de encarnação (no sentido de se tornarem parte da "carne" do sujeito).

A percepção musical em Dalcroze tem como base um corpo posto em movimento num determinado espaço, sem o qual não se constitui um ritmo, considerando-se a energia empregada em associação à fração de tempo que dura. A partir disso elabora oito princípios fundantes de seu trabalho:

a) Ritmo é movimento;

b) Movimento é de essência física;

c) Todo movimento exige espaço e tempo;

d) A experiência física forma a experiência musical;

e) O aperfeiçoamento dos meios físicos tem por consequência a nitidez da percepção;

f) O aperfeiçoamento dos movimentos no tempo assegura a consciência do ritmo musical;

g) O aperfeiçoamento dos movimentos no espaço assegura a consciência do ritmo plástico;

h) O aperfeiçoamento dos movimentos no tempo e no espaço devem ser adquiridos por exercícios de ginástica rítmica.

Para Cintra, o "sucesso do Método de Dalcroze depende de um movimento corporal completo por parte do aluno, que reage às propostas de movimento e, por sua vez, coloca as suas próprias, sempre em interação com o meio, em busca da autonomia rítmica. $\mathrm{O}$

\footnotetext{
${ }^{68}$ CINTRA, Fabio de Melo Cardozo. A Musicalidade como arcabouço da cena: caminhos para uma educação musical no teatro. Tese de doudorado. São Paulo. CAC/ECA/USP, 2006, p. 71
} 
corpo ativo do aluno vai aos poucos, nesse processo, construindo um conhecimento musical que vem da descoberta pessoal e não através de modelos impostos." 69

Longe de considerar o Método de Dalcroze modelar, é preciso reconhecer sua importância para a criação e a pedagogia da arte, considerando ainda as ressonâncias que causou no pensamento musical. Traz duas ideias que precisamos levar para o trabalho da musicalidade no ator. A primeira é da incorporação ou encarnação dos saberes, pelo qual o pensamento se alastra por todo o corpo e passamos a multidirecionar a escuta, em sentido amplo, para nossos órgãos e emoções, sem perdê-la dos ouvidos e do trabalho mental. Isso se relaciona à noção da não-disjunção quando propõe para o desenvolvimento musical uma construção global, que envolva tudo ao mesmo tempo e agora, portanto, muito mais abrangente que os métodos tradicionais que difundem a primazia dos ouvidos apenas (sem necessariamente trabalhar todas as modalidades de escuta).

A segunda refere-se ao fato de sempre estarem presentes cinco elementos: corpo, espaço, tempo, energia e ritmo.

Se musicalidade compõe as conexões afetivas e instintivas que possibilitam e determinam nossa movimentação musical e se ela é essencial para a construção de sentidos, podemos dizer que as relações estabelecidas entre os cinco elementos enumerados é um dos fundamentos para o trabalho a partir da musicalidade.

Em outras palavras, trabalhar a musicalidade no ator é colocar em constante fricção esses elementos, corpo, espaço, tempo, energia e ritmo. O corpo, o espaço e a energia, são o próprio material a ser trabalhado. Sobre eles devemos debruçar nossa atenção, para construir investigações e estudos capazes de criar um repertório emancipador do ator enquanto compositor da interpretação e das relações cênicas. Esse material será organizado a partir do recipiente do tempo e do ritmo, que funcionarão como propulsores e/ou opositores a serem enfrentados no tecido criativo sobre o qual se insere o trabalho do ator.

${ }^{69}$ CINTRA. 2006. op. cit. p.73-74 


\section{A musicalidade na Poética de Meyerhold}

A arte da encenação é saber harmonizar, pelos jogos de cena,o tecido melódico do espetáculo, este é o jogo dos atores Vsévolod Meyerhold ${ }^{70}$

\subsection{Bebendo musicalidade na fonte}

O trabalho do ator, todos sabemos, ganhou novo olhar e novo desenho a partir da escola russa, desde o final do séc. XIX, com ressonâncias em todo o mundo ocidental. Essa escola tem precedentes muito sólidos e essenciais para o pensamento sobre o trabalho do ator, notadamente na figura e na obra de Constantin Stanislaviski e no TAM (Teatro de Arte de Moscou), que possuía objetivos claros para buscar outras formas de atuação e direção nos palcos russos, superando as técnicas declamativas, os repertórios limitados e os descuidos com o design de visual.

Para isso Stanislaviski criou um sistema ${ }^{71}$ embasado em alguns princípios como "Circunstâncias Propostas", "Imaginação", "Se Mágico", "Comunhão", Coletividade", entre outros, dos quais destacamos aqui as "Ações Psicofísicas", por sua relação direta com a musicalidade.

Segundo as ações psicofísicas, é necessário que o ator responda sempre com uma ação, ou seja, traduza a sua imaginação das circunstâncias de forma artística, traga esse mundo imaginário para o aqui e o agora. Ele considera que um ator deve estabelecer movimentos plásticos em batidas compassadas de energia, a partir do tempo e do ritmo, transmitindo o

\footnotetext{
${ }^{70}$ Apud PICON-VALLIN. 2006. op. cit. p. 49

${ }^{71}$ Utilizamos a palavra Sistema, como a maior parte dos estudiosos, pois pode ser entendido como um conjunto articulado em rede, algo que mesmo múltiplo é tecido junto e portanto suas partes formam um todo cujo sentido não se fixa, mas está em constante ebulição, já que possui caráter modernizante. Algumas pessoas utilizam a palavra Método, no entanto este refere-se ao modo como cada pessoa se relaciona a algo, uma construção entre o que traz o indivíduo e o que sua individualidade faz disso.
} 
espírito interior do papel que interpreta, abastecido pela vida, a fim de dar verdade à atuação.

Toda esta elaboração sobre o movimento, a sonoridade, o tempo e o ritmo, como o próprio Stanislaviski cita em suas obras, bebe na ideia de musicalização e rítmica, esta última elaborada por Dalcroze e apresentada no capítulo anterior (item 2.3).

"A rítmica não é um fim em si, mas um meio para combater as inabilidades, inibições, de reencontrar uma harmonia perdida. Os exercícios despertam o sentido muscular, rítmico, auditivo e, desencadeando imagens no cérebro, desenvolvem faculdades imaginativas ao mesmo tempo em que o sentido de ordem e equilíbrio.(...)"72

A rítmica vinha ao encontro do trabalho de Stanislaviski sobre as ações físicas, enquanto alicerce da plasticidade do movimento. Nas palavras de Wolf Dorhn, que criou o Instituto Alemão de Hellereu para Dalcroze, “(...) a expressão da necessidade mais íntima, da aspiração mais secreta (...) o ritmo tornou-se para nós uma noção quase metafísica, espiritualizando o que é corporal e encarnando o que é espiritual”73.

O objetivo primeiro para Stanislaviski é o processo criativo do ator sobre si mesmo. Colocar o sujeito "em situação", pois sem isso nenhuma outra coisa pode ser feita. Para que isso aconteça, parte da ideia de que psíquico e físico são juntos. Sobre o que afirma: "a princípio somente se pode realizar isto..."74 No final o que resulta é "eu estou", não é o outro, nem a personagem, mas o próprio ator. Aquilo que a personagem resulta não é a representação dele, é o que ele é, o que o ator fez dele.

$\mathrm{Na}$ obra "El Evangelio de Stanislávski según sus apostoles, los apócrifos, la reforma, los falsos profetas y Judas Iscariote",

\footnotetext{
${ }^{72}$ ASLAN. 2008. op. cit. p. 41

${ }^{73}$ DORHN 1911, p. 90 apud ASLAN. 2008. op. cit. p.42

74 JIMENEZ, S. (org.) El Evangelio de Stanislávski según sus apostoles, los apócrifos, la la reforma, los falsos profetas y Judas Iscariote. México: Gaceta, 1990, p 244 - nossa tradução
} 
JIMENEZ (1990) traz a ideia de que o artista precisa encontrar a si mesmo, já que o sentimento vivo é do ator e não da personagem. Na ausência dele não há "se" mágico, e consequentemente não há personagem. Portanto, é a musicalidade do ator que está em jogo, alternando-se nos tempos propostos pelo texto e nos descobertos por ele próprio.

Stanislavski define tempo como a rapidez com a qual se alternam períodos iguais de uma medida qualquer que, por convenção, são tomados como unidades. Enquanto ritmo é a relação dos períodos efetivos (de movimento, som) que dizem respeito aos períodos estabelecidos por convenção como unidades em um tempo e medida determinados. ${ }^{75}$ Há uma relação clara e direta com a música, a diferença é que, enquanto a matériaprima do compositor musical é o som, o ator tem a si mesmo como matériaprima de sua composição.

Se o tempo-ritmo é tomado adequadamente, o sentimento e a vivência correta criam-se, naturalmente, por si mesmos; mas se o escolhemos equivocadamente, de igual modo surgirão, em distintos momentos do papel, sentimentos e vivências equivocadas, que não podem ser corrigidas se não pela modificação nesse tempo-rtimo. Se $o$ ator sente intuitiva e corretamente o que diz e faz em cena, o tempo-ritmo adequado se manifesta espontaneamente, distribuindo as passagens frágeis e débeis da linguagem, e os pontos de coincidência. Se isso não ocorre, só nos resta despertar o temporitmo pela via técnica, ou seja, ir do externo ao interno.

Stanislávski admite, mais adiante, que "o tempo-ritmo da ação pode sugerir de modo intuitivo, direto, imediato, não só os sentimentos correspondentes" sobre a memória emotiva e sobre a imaginação nas ações musicais".

Também seria errôneo considerar a ação física só como um movimento plástico que expressa a ação. É uma ação autêntica,

\footnotetext{
${ }^{75}$ Stanislavski,Constantin. El Trabajo del Actor Sobre Si Mismo. Buenos Aires: Ketzal, 1983, p 57

${ }^{76}$ Idem ibidem
} 
logicamente fundada, que persegue uma finalidade concreta e que, no momento de sua execução, se converte em uma ação psicofísica. ${ }^{77}$

Stanislávski defende a estreita ligação entre os aspectos físicos e psíquicos presentes na ação quando afirma que "não há ação física sem desejo, aspiração e objetivo, sem sua justificação interior pelo sentimento"78, assegurando assim a indissociabilidade corpo-mente que anos depois afirma-se no pensamento grotowskiano.

Seria então a ação física o caminho mais curto à emoção?

Sabemos que Stanislaviski, quando trabalhava sobre as ações físicas, superou, por aprofundamento, sua ideia da "memória emotiva". Seria Grotowski, anos depois de Stanislávski, que, continuando as pesquisas stanislavskianas sobre os processos criativos do ator, desenvolveria ulteriores considerações sobre estes e conceberia o termo corpo-vida como referente à unidade corpo-mente? Teria ele aproveitado alguns conceitos já então alargados por Meyerhold?

Independentemente dessas respostas, que não nos propomos investigar aqui, é evidente que já havia no Sistema desenvolvido por Stanislaviski um trabalho do ator sobre si mesmo a partir da musicalidade, que constitui a base para a ampliação e aprofundamento proposto por Meyerhold.

Meyerhold foi aluno e discípulo de Stanislavski, trabalhando juntos em diversas oportunidades, sendo natural que este tenha servido como fonte para o trabalho daquele. O próprio Meyerhold escreveu: "Comecei por imitar servilmente Stanislaviski (...) é útil para os jovens copiar os bons modelos: isso dispõe-nos para a independência interior (...) A imitação de um artista de que nos sentimos próximos, permite que nos definamos totalmente" ${ }^{\prime \prime 9}$.

\footnotetext{
${ }^{77}$ TOPORKOV,V. Stanislavski Dirige. Argentina: Compañia Geral Fabril Editora, 1961, p. 411

${ }^{78}$ TOPORKOV, V. op.cit., p 412

${ }^{79}$ MEYERHOLD. Vsévolod. O Teatro Teatral. Trad. Redondo Júnior. Lisboa: Ed Arcádia, 1980, p 27/28
} 


\subsection{Reação ao naturalismo}

Os alicerces da musicalidade proposta neste trabalho para a composição do ator originam-se daquilo que pudemos estudar e praticar sobre a pedagogia meyerholdiana ${ }^{80}$. Daí ser necessário compreender o contexto histórico-teatral em que foram desenvolvidas.

Meyerhold talvez tenha sido quem mais aprofundou e superou os princípios que Stanislaviski iniciou, mas todo seu esforço vinha principalmente do desejo de criar um ator que fosse capaz de dar conta de um teatro para além da mimese. Que fosse capaz de compreender a encenação, o texto e seu próprio papel de criador, possibilitando diálogos da obra teatral com o público. Um ator que fosse autônomo no conteúdo e na forma.

Nesse percurso, foi um fervoroso crítico do naturalismo, principalmente enquanto fórmula de repetição da vida e da mimese, enquanto conteúdo do trabalho teatral.

"Não é na capacidade de refletir a inteireza do real - isto é, as representações e as suas modificações no tempo - que consiste a arte. Esta descompõe o real tomando emprestadas, às vezes, as formas espaciais e, às vezes, as formas temporais. Isso se dá porque a arte liga-se à ideia - e então surgem as formas estéticas do espaço - e, as mudanças de ideia - e então surgem as formas temporais. 'A impossibilidade de exaurir o real em toda a sua inteireza leva à esquematização da realidade (e em particular, à estilização). ${ }^{81}$

Esquematização. Nesta palavra ressoa um implícito conceito de empobrecimento da realidade. A estilização está ligada a uma certa verossimilhança e consequentemente é ainda uma forma analítica por excelência. $O$ grotesco, que é a segunda etapa na via da estilização, rompeu os pontos com a análise. O seu método é rigorosamente sintético. O grotesco, ignorando todas as minúcias, sem algum

\footnotetext{
${ }^{80}$ Isso ocorreu a partir de livros e textos do próprio Meyerhold ou que fale sobre ele, de cursos com a professora Maria Thais e o professor Fabio Cintra e, principalmente, acompanhamento, aulas e treinamento por mais de 2 anos com a professora Yedda Chaves.

${ }^{81}$ A frase é de Andrei Bieli, As formas de Arte
} 
compromisso cria - naturalmente com a inverossimilhança intencional toda a plenitude da vida." ${ }^{22}$

Ao escrever sobre Charles Chaplin, Meyerhold traz um conceito tão importante quanto do grotesco, o excêntrico, pelo qual "visa transformar o material psicológico em teatralidade, criando através da imprevisibilidade uma nova percepção do fato já conhecido"83.

"Mostrar não um homem que come, bebe, ama, caminha, veste o casaco, mas mostrar um homem cuja natureza interior nós queremos revelar em toda a sua mais sinistra monstruosidade" ${ }^{84}$

Não é só pelo grotesco, mas toda a prática meyerholdiana funda-se em princípios que buscam um ator que seja capaz de tomar uma posição diante da personagem (ou tipo), rompendo a quarta parede e jogando com o público. Isso por si só já significa um distanciamento evidente do naturalismo.

Jonathan Pitches traz um exemplo de encenação em que Meyerhold, juntamente com a atriz Vera Komissarzhevskaya, desenvolve um princípio de reação à interpretação naturalista. Trata-se da peça "Casa de Bonecas", de Ibsen, especificamente a cena da "tarantela", da qual recorta um fragmento de poucas falas entre Nora, Helmer e Rank, onde Helmer tenta coreografar sua esposa-boneca para uma desempenho na festa de natal ${ }^{85}$ :

\section{"UMA TARANTELA NATURALISTA}

Mesmo se você não souber muito sobre o naturalismo, uma leitura profunda do fragmento dará a você boas dicas. Como um primeiro ponto de vista você precisaria:

- $\quad$ Elenco: Um ator para cada personagem: Nora, Halmer e Rank

- $\quad$ Figurinos: Talvez figurino de época, com um vestido longo para Nora

\footnotetext{
82 MEYERHOLD, V. E. Existem Dois Teatros de Marionetes. In Revista La Rivoluzione Teatrale. Trad. Edição e notas Giovanni Crino. Roma: Ed. Riuniti, 1962, apud CHAVES, Yedda C. 2001. Op.cit., p. 87

${ }^{83}$ CHAVES. 2001. op. cit. p. 86

${ }^{84}$ MEYERHOLD, V. E. Chaplin e Chaplinismo. In Lattore Biomeccanico. Trad e notas de Fausto Malcovati. Milano: Feltrineli, 1977. p. 47

${ }^{85}$ Ver anexo $\mathrm{A}$
} 
- Cenário: Uma sala do século 19

- Adereços: Piano, banquinho, tamborim, caixa e xale

- $\quad$ Aprenda a música da Tarantela

- $\quad$ Aprenda as falas e diga-as como estão no texto

Uma vez feito o trabalho inicial, você precisa desenvolver as personagens, talvez perguntando sobre seu passado, suas motivações ou seu objetivo particular na cena. Você estaria interessado em saber o que acontece antes e depois do fragmento e você teria que ensaiar muito para que as marcações no palco estivessem muito bem observadas, por exemplo o cabelo de Nora solto, bem na hora exata.

Mas há uma outra forma...

UMA TARANTELA DE CONVENÇÃO (ESTILIZADA)

O termo "estilizada" 86 persiste de uma história de usos inexatos e imprecisos. É muito comum as pessoas descreverem uma produção como "estilizada" se ela é vagamente não naturalista ou, pior ainda, se não estão certas de que estilo está sendo utilizado! Para Meyerhold, o verbo "estilizar" significa algo bastante específico e nós podemos entender isso se seguirmos o trabalho feito com "A casa de bonecas". Meyerhold nos dá algumas pistas sobre o que ele quer dizer com Estilização neste artigo: "On Naturalism":

'Tantas vezes se vê excessos no teatro naturalista; nada se sabe do poder da sugestão. No entanto, alguns artistas já fizeram uso disso, mesmo no apogeu do naturalismo: a tarantela de Vera Komissarzhevskaya era não mais do que uma série de poses expressivas durante as quais os pés nervosamente sapateavam um ritmo fervoroso.' (BRAUN 1991: 25)"

Neste ponto se faz importante um esclarecimento terminológico. Em oposição ao teatro que imita a vida, Meyerhold resgata a ideia do teatro como o local da convenção. Sabemos que não é a vida real e

\footnotetext{
${ }^{86}$ Mantivemos a palavra estilizada pela tradução no original em inglês, mas gostaríamos de acrescentar ao seu significado a ideia do Teatro de Convenção, defendido por Meyerhold e explicado nos tópicos a seguir (3.3.2.)
} 
sabemos que não se trata da vida das personagens, mas atores que as representam nas situações cênicas. A partir daí convencionamos os papéis da plateia e dos atores, por exemplo, na construção desse lugar para além do real. Assim falamos em Teatro de convenção.

"Mesmo que ele não diga claramente neste ponto, Meyerhold está descrevendo o processo de estilização. Komissarzhevskaya, sua parceira de trabalho em São Petesburgo na época, optou por não usar os movimentos da tarantela, mas simplificá-la em um série de poses expressivas, seguida de um ritmo distinto. Fazendo isso, ela seguiu três passos claros da estilização:

1. Simplificar e reduzir algo para encontrar sua essência;

2. Estender a gama de expressões;

3. Prestar atenção particular à questão do ritmo.

Sete princípios aprovadas por Meyerhold sobre o Teatro de Convenção

- A ênfase é no ator, trabalhando com o mínimo de acessórios e cenário;

- O espectador é instigado a usar sua imaginação;

- $\quad$ O ator trabalha sobre plasticidade física e expressão;

- $\quad$ As palavras do texto podem ser musicalizadas pelo diretor;

- $\quad$ O ritmo se torna mais importante para as mentes do diretor e dos espectadores;

- O visual do trabalho é construído cuidadosamente, como a pintura de um quadro;

- $\quad$ teatro estilizado pode produzir qualquer tipo de peça, de Aristofanes a Ibsen.

Então, para retomar o exercício, você tem rédeas livres no texto, mas você precisa comunicar a essência da cena. Você pode reduzir os recursos técnicos para absolutamente o mínimo. Você precisa pensar como um pintor e construir a cena com olhos 
conscientes para a forma, linhas e cores. Acima de tudo, você precisa desenhar na expressividade física de sua atuação, concentrando todo o tempo no ritmo: o ritmo do diálogo, o ritmo dos movimentos dos atores, o ritmo das formas criadas quando os atores se juntam no palco." ${ }^{87}$

Esse olhar sobre Meyerhold nos dá a dimensão de quanto atual é o teatro que propõe, pois que uma reação ao naturalismo, ele resgata a teatralidade da cena. Coloca em cheque a mimese e lança a necessidade de um olhar sobre o público. Tudo isso a partir do trabalho do ator, que se torna compositor de sua encenação, em diálogo com todas as demais composições em jogo, pois é um elemento da cena tão importante quanto a iluminação, a sonoplastia, o cenário, o design de visual ou figurino etc.

E talvez não haja movimento melhor para possibilitar todo esse distanciamento do naturalismo a partir de um aprofundamento no cotidiano, que a musicalidade. Ela está presente em tudo e é múltipla por si. É capaz de dar conta das multiplicidades do ator, da personagem, das relações estabelecidas por eles com o espaço e com os demais atores e demais personagens, de modo muito mais simples que qualquer tentativa de desenho nosso.

"A recriminação da submissão do ator ao encenador, que o transformava em uma "marionete", não é infundada. Ao privar o ator do gesto vivo, realístico, ao impor uma entonação "artística”, ao invés da entonação "lógica", Meyerhold se distanciou da reprodução da vida na cena, concretizando o princípio simbolista - 'na arte, tudo não como na vida, mas como na super vida'." 88

Era necessária a compreensão de uma nova musicalidade para o trabalho do ator, assim como acontece hoje. Quebrar com a obviedade da música da vida cotidiana, e isso somente se poderia alcançar pelo mistério e pelo inacabado. O oposto disso, o teatro naturalista, transforma a arte teatral numa ilustração das palavras do dramaturgo.

\footnotetext{
${ }^{87}$ PITCHES. Jonathan. Vsévolod Meyerhol. London: Routledge, 2003, p. 50-52. Tradução nossa com auxílio de Luiz Rodrigues Junior

${ }^{88}$ THAIS. 2009. op. cit. p. 35-36
} 
"Ainda ouço esse cão a uivar, diz uma personagem, e, ato contínuo, reproduz-se o uivo. A partida é significada não só pelo som dos guizos dos cavalos que se afastam, mas até pelo ruído de suas patas sobre a ponte de madeira. Ouve-se a chuva cair sobre o telhado. Aves, rãs, grilos.

A este propósito, citarei conversa de Tchekov com os atores (...): O Teatro é arte. Pegue um bom retrato, recorte o nariz e introduza no buraco um nariz verdadeiro. Talvez seja mais real, mas o quadro fica estragado." 89

${ }^{89}$ MEYERHOLD. 1980. op. cit. p. 34 


\subsection{Teatro de Feira (Balagan) e Teatro de Convenção}

A Rússia se formou a partir do séc. XI, pela unificação de tribos slavas (a maioria nômades), possuindo Kiev como primeira capital. Naquele local deu-se o encontro da cultura slava com a cultura nórdica, representada por comerciantes invasores, já que a Rússia é um "pais de passagem" entre oriente e ocidente. Com religião ortodoxa, idioma organizado por monges gregos (alfabeto cirílico) e é preciso considerar ainda que sofre influências muitos outros povos.

Em algumas disciplinas cursadas durante este mestrado, tive a oportunidade de estabelecer trocas com a professora Maria Thais ${ }^{90}$ que foram fundamentais para iniciar uma compreensão sobre o povo russo e, portanto, o modo como pensam e agem em relação à vida e à arte, a partir das vivências que ela teve lá. Muitas das coisas que aprendi com a professora sequer caberiam neste trabalho, mas há algo, dentre as coisas que não caberiam, que, por ser essencial ao mergulho no pensamento russo, gostaria de compartilhar.

Trata-se do pensamento global ou "coletivo desde o indivíduo", que, imagino, dá-se como resultado de toda história de como este povo foi forjado, e pode ser observado principalmente por dois motivos.

O primeiro deles é sobre a inexistência do verbo "ser" no presente. Só existe no passado ou no futuro. No presente, digo "eu Cadu" e não "eu sou Cadu", portanto eu já sou e não preciso dizer. Não é uma língua reinterativa, uma vez que não reafirma o que já é. Não há representação sobre a coisa, pois fala da coisa em si.

O segundo vem da religião Ortodoxa, principalmente do fato de a Santíssima Trindade prever a igualdade, são apenas um: Pai-FilhoEspírito Santo e não três, com vírgula e "e": Pai, Filho e Espírito Santo, como no ocidente. Em termos concretos para o ocidente há certa hierarquia, ao

\footnotetext{
${ }^{90}$ Cursei duas disciplinas com a professora Maria Thais Lima Santos: sobre o encenador Vassiliev, em 2009, como ovinte e "Da pedagogia à cena, da cena à pedagogia", em 2012
} 
menos linguística, onde prevalece o Espírito Santo e o caráter de divindade espiritual da religião, mas no oriente a carne não se separa do espírito, são unos.

Essa ideia de pensar globalmente, de que todos somos ligados e formamos, concretamente, uma unidade, nos permite exercitar melhor conceitos como incorporar/encarnar a personagem. Não se trata de movimentos espirituais, nem de psicologismos endocêntricos, mas de processos para o ator emprestar pele, carne e ossos para a interpretação.

Isso contribui enormemente, também, no trabalho a partir do unitas multiplex, já que é inerente ao pensamento a união de coisas que a ciência quis separar, como por exemplo a carne, a mente e o espírito humanos. Uma ação portanto nunca será apenas física, nem apenas psicológica, não podendo ser realizada de forma a dissociar o interior e o exterior do agente. Mas o mais importante é que não será uma prevalência de um sobre o outro, simplesmente porque são tecidos juntos e não podem ser separados.

\subsubsection{Teatro de Feira ou Balagan}

Partindo das ideias trazidas sucintamente sobre o povo russo, gostaríamos de pensar a ideia de Teatro de Feira, ou no vocabulário de Meyerhold, Balagan. A palavra Balagan é de origem tártara e se referia às barracas armadas em terrenos baldios, onde se realizavam feiras e eram apresentadas cosias extraordinárias ao público. Estavam presentes todas as artes do espetáculo. A noção de Feira lá é diferente da que possuímos em relação ao que acontece hoje no Brasil, com as feiras populares de cultura, ou mesmo aquelas onde compramos legumes, verduras e tantas outras coisas. Balagan diz mais respeito ao teatro de marionetes, pois não é necessariamente feito numa feira como a que imaginamos. Assim, a discussão não é entre erudito e popular. 
"Enquanto que no teatro burguês, os gêneros se diferenciam uns dos outros, o "teatro de balagan", que se desenvolveu a partir das pantomimas dos atores italianos em turnê pela Rússia, conserva uma forma sintética e opera entre eles uma fusão ainda mais estreita, graças aos atores que são também acrobatas, funâmbulos, mágicos, engolidores de fogo, palhaços, Fregoli". As sessões de "drama de balagan" acontecem sob um fundo cacofônico de realejos, rangidos de carrosséis, tiros, piadas e chamados dos que fazem o reclame do espetáculo, respostas berradas pela multidão de espectadores que flanam pelo parque e gritos dos vendedores." ${ }^{92}$

É uma expressão fortemente polifônica na forma e no conteúdo, contando com uma fricção necessária entre as atividades de todos os artistas envolvidos. Não havia uma separação nítida entre linguagens, como prezou mais tarde o séc. XX, nem entre os profissionais da arte. Essa fusão não pretendia resultar em nada, apenas era isso. Teatro, dança, música, circo, artes plásticas e literatura não possuíam fronteiras, nem se nomeavam como tais, produzindo arte teatral, "esse mundo no qual as leis são fundamentalmente diferentes das da vida cotidiana e cuja forma a cena contemporânea, por demais livresca, esqueceu"93.

"O balagan, porque soube reunir, confrontar, associar, 'montar' (no sentido cinematográfico) os campos de feira de múltiplos gêneros e tradições nômades, vai progressivamente se tornar, na reflexão meyerholdiana, um conceito de trabalho que globaliza de modo sincrético as formas menores de cultura espetacular (circo, Commedia del'Arte, cabaret, variedades, überbrett ${ }^{94}$ alemão, pantomima) trazidas para o primeiro plano e consideradas como forças vitais, necessárias para reconstruir o teatro do futuro sobre bases sólidas, profissionais, tanto no plano do velho ofício do ator quanto no plano, novo, do encenador (composição, estrutura do espetáculo). Brevidade e

\footnotetext{
${ }^{91}$ Fregoli: clown especializado em desaparecimentos.

92 PICON-VALLIN, Béatrice. A cena em ensaios. Trad. Fátima Saad, Claudia Fares e Eloisa Araujo Ribeiro. São Paulo: Perspectiva, 2008, p.3

${ }^{93}$ Idem ibidem, p. 5/6

${ }^{94}$ Espécie de saraus com literatura e variedades, o termo alemão é usado por Ernest Von Wolzogen, a partir de 1902 em Berlim.
} 
contrastes, profundidade e concisão, fragmentação e precisão. O Teatro de Feira penetra no coração das coisas e dos fenômenos para exprimi-los em imagens, livres da barulheira sem sentido dos autores contemporâneos." 95

Exatamente por isso não devemos tentar traçar um sentido uníssono ao Balagan. Ele se constitui e se faz necessário na multiplicidade. Nesse artista completo e nessa peça de feira na qual se concentram todos os gêneros, todas as artes, todos os registros.

Ao abordar o Balagan e sua importância para o teatro, Meyerhold inicia a terceira parte de seu livro, Do Teatro ${ }^{96}$, falando em Mistério. Começa analisando uma carta de Bernois sobre "Irmãos Karamazov", onde desclassifica a palavra Mistério ali empregada, aproximando-o de ministeruim (de cunho religioso, ligado à antiguidade) e afastando-o daquilo que se deseja no teatro. A questão que levanta: é chegada a hora do Mistério no Teatro? Seria o Teatro capaz de recebê-lo?

"O homem obtém, no 'Poema do êxtase', a felicidade advinda da consciência de que ultrapassou o caminho tortuoso e que agora escuta o ressoar da hora da arte. Nessas etapas Skriábin ${ }^{97}$ alcançou material não pouco valioso e que se encontra preparado para ser utilizado num ritual grandioso, ao ser encenado por um Mistério, em que se uniram a harmonia e a música, a dança, a luz e o inebriante cheiro de flores silvestres." 98

Quando fala de Mistério, está colocando o público no lugar do fiel, que tem que crer no que vê enquanto absoluta verdade, uma vez que é dogma da religião. Por outro lado, quando fala em barraca de feira está falando do "ilusionista" que cria fantasias para quem está assistindo. Mas, no

\footnotetext{
${ }^{95}$ Idem ibidem, p. 4

${ }^{96}$ Tentamos aqui utilizar as três traduções disponíveis em língua portuguesa, que constam em nossa Bibliografia, e construir a partir da compreensão do trabalho do mestre russo as colocações que mais pudessem colaborar com o entendimento desta obra.

97 Skriábin é compositor. Morto jovem. Fazia parte da vanguarda russa. Tem a particularidade de entender a música enquanto elevação espiritual. Imaginava o teatro como um culto, "quase religioso".

${ }^{98}$ MEYERHOLD. 2012. op. cit. p 186
} 
trabalho de Skriábin não há esse lugar, porque ele busca uma conexão entre palco e plateia, então o público só poderia estar ali se quisesse.

"Quando falamos sobre Mistério e sobre sua criação para o largo público, sempre gosto de apontar para dois fenômenos da história do teatro francês que poderia nos ensinar alguma coisa.

O primeiro são os Confrères de La Passion, que mantendo fortemente as convenções dos mistérios originais, deveriam se limitar estritamente à comunidade da santíssima trindade, apresentando-se apenas para os membros da Igreja, o que levou à criação da Casa dos Mistérios.

Já os funcionários da Corporação de Bazochi, por outro lado, saíram às ruas apoiando-se sobre as bases da pantomima. E foi então que se criou o verdadeiro teatro, nessa estreita união entre os histriões e o povo.

Delinearam-se, assim, nitidamente, dois campos da ação pública: o misterioso e o teatral.

\section{(...)}

Estou certo de que enquanto os criadores do Neomistério não romperem de vez com 0 teatro, enquanto não saírem dele definitivamente, o mistério irá atrapalhar o teatro e o teatro atrapalhará o mistério." ${ }^{99}$

Meyerhold quer por fim a esse misticismo de fachada. Entende que se o teatro não se constitui como um lugar de construção para o público, que a partir daí faz suas analogias e conexões, passará a iludi-lo. É nítido seu confronto com o naturalismo.

A operação de criar um campo simbólico e ao mesmo tempo quebrar o que foi criado não é um movimento artístico aceito pelo naturalismo, pois ele quer crer no que criou até o fim. Contrariamente, o mestre russo entende que a arte é arte e não quer ser outra coisa, senão arte. Não importa retratar a vida, diferentemente de Stanislaviski que discute a arte em relação à vida e, portanto, quer imitá-la em certo nível.

${ }^{99}$ Idem ibidem 
É importante que tenhamos a noção de que Meyerhold é encenador do teatro imperial quando escreve, em seu livro "Do Teatro", este texto sobre Balagan; então quando fala, o faz a partir deste modelo de teatro. Após 1898 os teatros imperiais passam a coexistir com outros modelos de teatro. Então, outras formas de teatros, como Commedia del'Arte, entram pela corte.

Portanto, falar em Balagan é resgatar a teatralidade. "A referência à Barraca de Feira é metafísica e histórica. (...) o balagan constitui a memória do teatro teatral." ${ }^{100}$

No texto, o discurso de Meyerhold está no plano da composição, mas não no plano de "como" o ator faz e sim "do que" ele faz. Está no plano da encenação. Portanto, aborda a cena e os aspectos pedagógicos que estão na cena, já que o ator é um elemento da composição.

Traz oposições entre as formas de interpretação, que merecem ser vistas ${ }^{101}$ :

\begin{tabular}{|l|l|}
\hline Máscara & Maquiagem \\
\hline Jogar & Viver \\
\hline Ficção & Realidade \\
\hline Criação & Cópia \\
\hline Ator cabotino & Ator camaleão \\
\hline Inverossimilhança & Verossimilhança \\
\hline Como na Arte & Como na Vida \\
\hline
\end{tabular}

A partir dessas confrontações, começamos a visualizar melhor as ideias que promovem para ele a atuação. A imitação da vida perde sentido e podemos dar lugar à arte da vida.

Escreve então sobre dois teatros de marionetes. Num, a tentativa de retratar com perfeição a vida humana é frustrada e a solução natural é substituir os bonecos por humanos. Noutro, percebe-se que o público

\footnotetext{
${ }^{100}$ PICCON-VALIN. 2008, p. 5-6

${ }^{101}$ Quadro pensado na disciplina Da pedagogia à cena, da cena à pedagogia orientada pela professora Maria Thais no CAC/ECA/USP em 2012, quando dos debates conduzidos pela professora em aula.
} 
se impressiona exatamente com a imperfeição e com a ausência de semelhança do que é apresentado em cena, com o que veem na vida.

"Descrevi esses dois teatros de marionetes para fazer com que 0 ator reflita: ele deve substituir a marionete e perseguir esse papel auxiliar, que Ihe recusa toda liberdade de criação pessoal, ou deve fundar um teatro análogo ao que a marionete soube conquistar, negando-se a se submeter à vontade do diretor de modificar sua natureza? A marionete não queria identificar-se completamente ao homem, porque o mundo que ela representa é o maravilhoso mundo da ficção, porque o homem que ela representa é um homem inventado, porque o estrado em que ela evolui é a mesa de harmonia onde se encontram as cordas de sua arte. É assim, e não de outra maneira, que ela age sobre seus estrados, não de acordo com as leis da natureza, mas de acordo com sua vontade - o que ela quer não é copiar, mas criar."102

$\mathrm{Na}$ interpretação realista, o ator passa a se deslocar num papel auxiliar. Parece que ele tem que adquirir algo para se colocar no lugar em que o dramaturgo quer, algo que não foi constituído por ele e, para isso, ele tem que recusar a liberdade de criação. A marionete, ao contrário, não nega sua natureza de marionete e os outros se serviram dessa natureza. Porque essa é a vontade e porque o que ela quer não é copiar, mas criar.

O que dá a ela a possibilidade de criar não é a presença ou não do manipulador, mas sua natureza, a natureza da matéria da qual ela é feita.

Há uma concepção diferente, é um ser múltiplo. Não há unidade, mas uma ação de metamorfosear. Trata-se da arte do ator transformar-se em múltiplos personagens. Não é pra revelar uma só faceta, como no exemplo do Arlequim, pela multiplicidade que a máscara permite, uma vez que a máscara, por si só, já traz isso. Meyerhold traz para o ator uma questão que não é a da personagem, mas a do ator compositor de uma cena.

102 MEYERHOLD, V. E. Do Teatro. Apud THAIS. 2009. op. cit. p. 332 


\subsubsection{Teatro de Convenção}

Meyerhold, desde seu início como ator de Stanislaviski, possui grande sede pela pedagogia teatral, praticando e refletindo incansavelmente novas possibilidades para a atuação e encenação. Bebe de muitas fontes, notadamente Commedia del'Arte e Teatro Oriental. Ministra diversos cursos, sempre pensando numa formação global.

"O encenador reconhece, no entanto, suas dificuldades na província. Em carta à mulher, Olga Meyerhold, em fevereiro de 1906, demonstra seu descontentamento com o desinteresse dos atores nas leituras indicadas e, principalmente, com os limites técnicos e vocais, que tornavam o temperamento o único atributo do intérprete. Nessas circunstâncias, concluía que o sonho de um Teatro-Escola não poderia jamais ser alcançado.

(...)

É neste período que Meyerhold transforma sua visão sobre o trabalho do ator e cultiva a concepção de uma nova escola, pois já não se satisfaz mais com a visão tradicional do diretor-ator; não a rejeita, mas a aprofunda, aperfeiçoa e constrói um outro esquema: diretorpedagogo-ator.

Nesta nova relação, aspirava ter o ator não como simples intérprete das ideias do diretor, mas como colaborador, criador, tomando para si a responsabilidade de prepará-lo."103

Entre 1913 e 1914, antes de mudar o Estúdio para a rua Borodinskaia, ministra um curso chamado "O Movimento Cênico", propondo desenvolver no ator a consciência de seu corpo no espaço cênico e em relação aos outros atores, incluindo neste trabalho variações utilizando elementos de cena. No mesmo espaço luri Bondi oferecia um curso sobre cenografia, figurino, maquiagem, iluminação e técnicas de palco, o qual Meyerhold recomendava aos atores e encenadores que formava, por entender fundamental em sua compreensão da arte da cena.

${ }^{103}$ THAIS. 2009. op. cit. p. 27-28 
Pensando no ator emancipado, privilegia uma formação essencialmente prática, dividida em dois momentos principais: os estudos e os extratos de cena. Mescla atores iniciantes com experientes. E "diferentemente dos professores habituais de arte dramática, Meyerhold não ensina, pois, o jogo do ator para interpretar a comédia. Ele procura despertar e desenvolver a capacidade de improvisação." 104

No entanto, o teatro para o qual Meyerhold preparava seus atores não encontrava respaldo no âmbito do naturalismo, pois derivava da convenção teatral, inebriado no perfume simbolista, onde mesmo o realismo poderia estabelecer seu jogo com o público. Mais tarde renuncia ao simbolismo, mas essa primeira dose seria essencial para alcançar suas ideias sobre $o$ ator, o encenador e a cena.

Em seu livro "Do Teatro", na primeira parte "Contribuição à História e à Técnica do Teatro", escreve um capítulo denominado "As Primeiras Tentativas de Criação de um Teatro de Convenção", no qual aponta para a possibilidade de experiências teatrais concretas, que não encontravam ressonância nos teatros tradicionais da época.

Guardadas as proporções e a distinção contextual, vivemos no Brasil, nesse início de séc. XXI, um momento muito próximo daquele em que o teatro "comercialesco" de reprodução da vida e nenhuma reflexão crítica alastrava-se pelos palcos da Europa. Considerando a espiralidade histórica a qual também se submete a arte teatral, podemos dizer que há uma certa oposição entre natureza e artifício, simples e complexo, ou, num sentido mais restritivo, entre apolíneo e dionisíaco ${ }^{105}$.

Enquanto as abordagens no tratamento naturalista da cena revelam certa ambição mimética, nas abordagens não-naturalistas busca-se o espaço da composição corpórea, que obviamente nos agrada

\footnotetext{
${ }^{104}$ ABENSOUR, Gérard. Vsévolod Meyerhold, ou, L'invention de La mise em scène. Trad. J. Guinsburg. São Paulo: Perspectiva, 2011, p. 275

105 Maria Thais, em seu livro "Na cena do Dr. Dapertuto: Poética e Pedagogia em V. E. Meyerhold: 1911 à 1916", dedica o capítulo 2, "Paradigmas para a arte da encenação e do ator" a traçar pistas para uma compreensão mais aprofundada da obra de Meyerhold a partir desta oposição.
} 
mais. O ator passa a inscrever em seu corpo a musicalidade da personagem e da cena, desenhando-a no espaço em fricções constantes com todas as áreas da encenação.

Para Meyerhold havia uma desarmonia entre todos os profissionais envolvidos no evento teatral, que não promovem os atritos necessários entre si para que componham um caminho polifônico de criação. Esse "desentendimento" fazia com que cada profissional se confinasse em seu ofício, não encontrando no teatro dramático papel além da subserviência.

Como realizar essa fusão com todos os profissionais the pareceu uma tarefa muito distante. Desta forma, no primeiro momento, buscou realizar esse trabalho, pelo menos com três deles: o autor, o diretor e o ator.

“...demonstrarei dois métodos da arte da direção que tratam diferentemente a relação entre o ator e o diretor: um dos métodos inibe a liberdade criativa não apenas do ator, mas também do espectador. $O$ outro liberta (...) forçando o último a não apenas contemplar, mas a criar (ainda que num primeiro momento na esfera de sua própria fantasia).

Os dois métodos se abrem, se colocarmos as quatro bases do teatro (autor, diretor, ator e público) em um desenho gráfico da seguinte forma:

1) Triângulo, em que o vértice superior é o diretor, e os dois vértices da base são o autor e o ator. $O$ espectador experimenta a arte dos dois últimos através da arte do diretor. Esse é um teatro: o "teatrotriângulo"

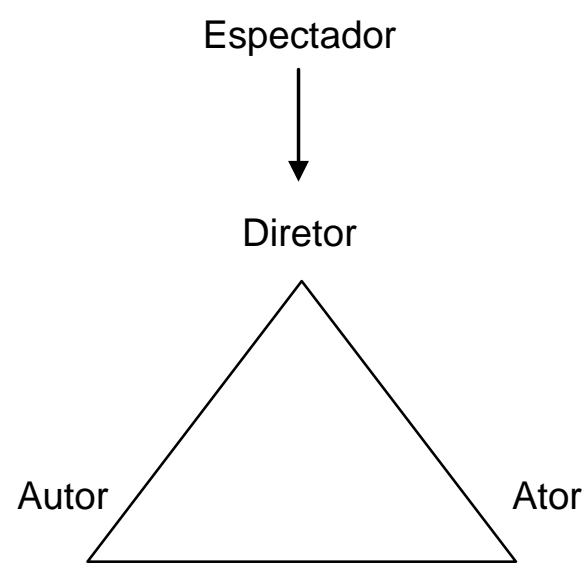


2) Reta horizontal, em que as quatro bases são notadas como quatro pontos da esquerda para a direita: autor, diretor, ator, espectador. Esse é outro teatro ("o teatro de linha reta"). $O$ ator abre livremente sua alma ante o espectador, tendo aceitado em si mesmo a arte do diretor, como este último teria aceitado em si a arte do autor.

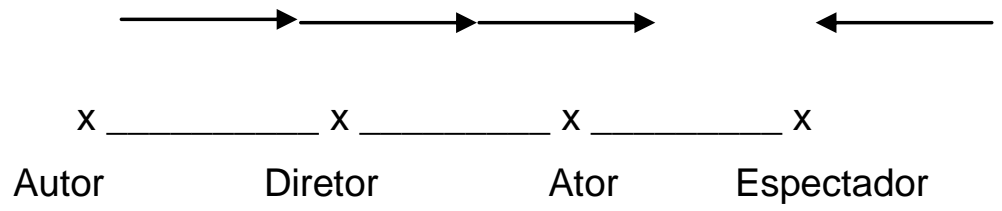

No "teatro triangulo" o diretor, depois de abrir seu plano em todos os mínimos detalhes, demonstrando as formas tais como ele as vê, indicando todas as pautas, ensaia até que toda sua concepção seja exatamente reproduzida, em todos os detalhes, até que se ouça e se veja a peça da mesma forma como ele a ouviu e viu quando trabalhava nela sozinho.

No "teatro de linha reta", o diretor, tendo filtrado em si o autor, leva ao autor sua criação (autor e diretor aqui se encontram fundidos). $O$ ator, acessando através do diretor a criação do autor, põe-se diante do espectador (estando o autor e o diretor às costas do ator), abre perante ele sua alma livremente, de forma que acaba por aguçar a interpretação entre as duas bases principais do teatro - o saltimbanco e o espectador." 106

Com o advento do $4^{\circ}$ criador, o público, Meyerhold traz duas importantes contribuições ao teatro mundial. A primeira é a necessidade de participação do público para que se complete o evento teatral. Não há mais uma ditadura do discurso cênico que impõe e explica absolutamente tudo, não provocando reflexão ou confronto. A segunda é a reação ao acabamento da obra, que pode manter-se pronta, mas completa-se apenas a partir das conexões que possibilita. Trata-se de torná-la porosa aos sentidos.

$\overline{106}$ MEYERHOLD. 2012. op. cit. p. 71-73 
De toda a plateia passam a ser exigidas ações no sentido de completar, mas não necessariamente concluir, os esboços gerados pela cena. E não importa se isso se dá de forma fantasiosa ou inexata, é o exercício que traz para o teatro o público. Ele será lembrado o tempo todo que está diante de uma peça, com cenários e atores.

Para que aquilo que o mestre russo chama de "fusão" aconteça, se faz necessária a instituição de um novo procedimento de criação cênica. As artes colaboram no processo criativo a partir das propostas improvisadas pelos atores, que se alimentam nas do diretor, alimentado pelo autor.

“...há uma relação orgânica entre o processo de criação da cena e 0 ator. Ao propor uma nova prática como encenador, Meyerhold colocou-os sob a regência dos mesmos princípios. Refez uma hierarquia secular, que era baseada principalmente na figura do dramaturgo. No seu projeto de um teatro de Convenção, Meyerhold propôs graficamente outra organização das funções na criação teatral: a linha reta horizontal. Criou uma estrutura em que todos são proponentes, em um processo de assimilação e provocação contínua; do autor para o encenador, deste para $\mathrm{o}$ ator $\mathrm{e}$, finalmente, do ator para o espectador, acentuando assim a ação recíproca dos dois elementos fundamentais do teatro - comediante e espectador." ${ }^{107}$

Essa retomada da convenção teatral, Meyerhold chama de "Ação Dionisíaca", a partir dos estudos feitos por Viachesláv Ivánov. Isto pois para ele o drama nasce do espírito da música em coro dos ditirambos, incrustados de energia dinâmica, mas também dos sacrifícios ao deus do vinho, de onde surge o culto extático.

O novo teatro que oferece representa um retorno à ancestralidade do próprio teatro. Onde não há disjunção entre carne, mente e espírito, portanto, mesclam-se na multiplicidade todos os elementos que

${ }^{107}$ THAIS, Maria. Op. cit. p. 39 
compõem a cena, rompendo definitivamente a quarta parede e todas as paredes que podem existir entre os componentes da criação cênica.

"O teatro deve desvelar definitivamente sua essência dinâmica; e assim, deve deixar de ser "teatro" no sentido de "espetáculo". Queremos nos reunir para criar, para "agir" em conjunto, e não somente para contemplar." ${ }^{108}$

O Teatro de Convenção é, para o ator, libertador, uma vez que cria uma tridimensionalidade múltipla, pois escancara com o palco italiano e a partir daí cria todas as possibilidades de cenografia, iluminação e sonoplastia, desobrigando o ator do uso de figurinos rigorosos, permitindo o pensamento sobre o design de aparência. Suprime o proscênio e rebaixa 0 palco ao nível da plateia.

Toda essa estrutura possibilita um novo olhar para a atuação. O ofício do ator se dá agora em outros planos: “... construídos a dicção e os movimentos dos atores no ritmo, aproxima a possibilidade do renascimento da dança, e a palavra em tal teatro facilmente se transforma em grunhido cantado, em silêncio cantado." ${ }^{109}$

\footnotetext{
${ }^{108}$ MEYERHOLD. Do Teatro. Apud THAIS. 2009. op. cit. p. 234

${ }^{109}$ MEYERHOLD. Do teatro. 2012, op cit. p. 88
} 


\subsection{A Biomecânica}

A abordagem artística de Meyerhold nos leva a refletir sobre seu modo de pensar e fazer teatro necessariamente em colaboração com os demais artistas. Sua prática nos situa na problemática da utilização pelo ator do "corpo + mente + emoção".

Para ele é exigência de qualquer arte que seu material exprima a condição dada pelo artista, revelando em seu jogo as formas que crê a partir do corpo humano.

"Como sabemos, o trabalho do ator envolve muitos elementos: ele se move, fala, ouve, constrói imagens interiores e exteriores, reage de maneiras diferentes a partir de diferentes estímulos, utiliza objetos, adereços etc. Elementos, portanto, de diferentes naturezas. (...) Foi a partir desse percurso de reflexão e da leitura de Aristóteles, que cheguei ao conceito de material.

\section{$(\ldots)$}

Por material pode-se entender qualquer elemento que adquire uma função no processo de construção da identidade do próprio

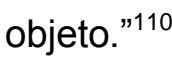

As conexões entre os gestos e as intenções se dão no corpo do ator, nos seus próprios gestos, mas também no corpo do outro e nas suas intenções legíveis. "O teatro é o domínio superior onde a palavra se faz carne."111

A ciência neurológica estava em pleno avanço a partir da segunda metade da década de 1910. Meyerhold passa a utilizar como fonte de trabalho os mais importantes cientistas da época, dentre os quais Ivan Pavlov.

\footnotetext{
${ }^{110}$ BONFITTO, Matteo. O Ator Compositor: as ações físicas como eixo: de Stanislaviski a Barba. São Paulo: Perspectiva, 2002, p. 41

111 (informação verbal) Frase de Meyerhold, sempre repetida pela Professora Yedda em nossos estudos-treinos
} 
Em suas encenações, Meyerhold, de 1917 a 1923 debruça atenção sobre o estudo do corpo do ator (entendido sempre em sentido amplo).

Em 1918 encena "O Mistério Bufo", de Maiakoviski. Em 1921 organiza o Laboratório de Encenação, para em 1923, fundar o Teatro Meyerhold (TIM). Nessa fase trabalha as palavras e sua desconstrução e traz para o teatro todas as possibilidades de utilizações de recursos cinematográficos. Com projeções em tempo real da rua ao fundo da peça, traz ao espectador a lembrança da vida "lá fora", sem deixar de fazer arte, ou ainda com projeções de falas do texto no cenário, deixando ao ator apenas a execução dos movimentos, provoca deslocamentos na encenação. Essas e outras inovações tecnológicas são experimentadas a fundo pelo encenador.

É nesta efervescência que Meyerhold irá formular os Princípios da Biomecânica, não como um conjunto de regras, mas como fontes ao trabalho do ator sobre si mesmo, emancipando-o para um teatro que emergia e que, em nosso tempo, salta das salas de espetáculo para toda sorte de espaço.

Sabendo que a Biomecânica merece um estudo mais detalhado, não nos empenharemos aqui em dar conta dela, mas apenas levantar pistas para que o leitor possa compreender seus princípios e como ela colabora no trabalho do ator hoje, notadamente em sua raiz na musicalidade.

As pesquisas de Meyerhold ultrapassam fronteiras entre ocidente e oriente e, como parece ser usual ao povo russo, bebem na tradição e nas vanguardas, sem contrapô-las, mas friccionando-as. Realizou estudos nos campos da música, literatura, artes plásticas, arquitetura e dança, buscando correspondências entre a teatralidade e as exigências ideológicas e psicológicas do texto.

Em meio ao formalismo russo e ao cubo-futurismo, nasce nos anos 1920 a Biomecânica. Resulta, claro, de todo o trabalho realizado no Estúdio da rua Borodinskaia (1913-1917) e como movimento de reação ao naturalismo. Tem em 1922 uma visibilidade que rendeu duras críticas com a apresentação do espetáculo "O Corno Magnífico", onde foram utilizados os exercícios biomecânicos. 
"Diante do fronte revolucionário, não temos ainda pontos precisos. Ontem não usávamos a maquiagem, hoje é possível. Estamos ainda no estágio de cada possível experiência e até quando não provaremos todas, deixe-nos recolher aos poucos os materiais. Se alguém disser: 'Desculpem, mas antes vocês disseram uma coisa, agora dizem uma outra', nós repetiremos mais uma vez que em 'O Corno Magnífico' o objetivo era essencialmente aquele pedagógico: colocar juntas, pela primeira vez, as experiências e as leis do teatro da Commedia del'Arte, da construção de esquetes e da trama das ações teatrais. Livres da maquiagem e dos figurinos, colocamos como prioridade a expressividade dos nossos corpos, estudamos as leis dos primeiros planos, depois as ações velozes, a dinâmica do diálogo, a atração da ação, tudo realizado somente com a ajuda do corpo do ator. Nenhuma cenografia, só o corpo humano. Nenhum ambiente, só equipamentos que permitam mostrar o corpo ora sob um ângulo, ora sob outro."112

Segundo a Professora Yedda Chaves, este foi o único caso de transposição direta do treinamento para a cena, o que não representa uma ruptura na pesquisa, mas demonstra seu caráter dinâmico na utilização dos meios técnicos configurados ao seu desenho sociopolítico e estético.

Ela realiza uma análise dos fragmentos em vídeo deste espetáculo e do "Inspetor Geral" (1926), constatando que tendem ao realismo, mais pelas soluções cênicas e pelas interpretações dos atores, que pela estética em si. Mas ressalta que continuavam indicando novas percepções, principalmente alterando as velhas percepções, a partir do jogo do ator com o espaço e o tempo, sempre com ênfase no movimento e no ritmo.

"O traço mais importante na atividade experimental do encenador russo, foi aquele da investigação dos princípios éticos e expressivos. Nessa investigação ele buscou os elementos que pudessem se submeter às leis da pintura e da música com o objetivo de construir uma nova significação cênica. Lógicas de atuação, como a excentricidade e o grotesco - em dose máxima ou mínima, perceptível

$\overline{112}$ MEYERHOLD, V. E. O Professor Bubu. In: L'Ottubre Teatrale. 2012. op. cit. p. 217 
ou subliminar -, sempre forma estratégias na arte do diretor, que se manteve essencialmente não realista.

Um papel fundamental nesse processo foi a Biomecânica. Ela permitiu que se chegasse ao um teatro 'orgânico e sintético' através do aprimoramento das suas técnicas. Ponto de extrema importância, sublinhado por Meyerhold, foi o processo de assimilação e releitura das técnicas pré e pós-revolucionárias que compõem todo o treinamento biomecânico." ${ }^{113}$

O sistema biomecânico de atuação, iniciando por uma série de dispositivos criados para desenvolver habilidades de controle corpóreo dentro do espaço cênico da maneira mais eficiente, promove técnicas complexas relativas à coordenação dos movimentos e das palavras, e as capacidades em despertar emoções e controlar a excitabilidade na performance.

As informações que dividiremos aqui vêm das práticas realizadas com a Professora Yedda, de alguns documentos escritos que ela pôde disponibilizar, de outros escritos do próprio Meyerhold, mesmo que escassos, de algumas transcrições de aulas dos seus alunos e de poucos fragmentos de filmes históricos.

Como já dito antes, são elementos fundamentais à Biomecânica o desenho dos movimentos e o ritmo das ações. Assim, é possível fazer uma correlação com as Artes Plásticas e com a Música, onde a arte do artista está intimamente ligada à composição. Este raciocínio, que foi trazido pela Professora Yedda em sua dissertação de Mestrado (2001) e depois aprofundado e ampliado por Matteo Bonfitto em seu livro "O Ator Compositor" (2002), é uma importante base do trabalho biomecânico.

“Em Meyerhold, a composição contém matrizes que refletem seu tempo, delineando-se mais como a técnica do 'deslocamento' dos acontecimentos, a fim de revelar relações inusitadas das estruturas dramáticas. Trata-se de um procedimento que coloca em evidência a contradição da ação para revelar a sua construção artística. (...) tem o objetivo de combater o automatismo da percepção, obtendo, desse

${ }^{113}$ CHAVES. 2001. op. cit. p. 37 
modo, uma visão completamente nova dos acontecimentos cotidianos" 114

Meyerhold quer, a partir das técnicas, criar novas reservas de qualidade para o ator. Seu objetivo é que o ator se muna de repertório para jogar com ele em cena de forma a revelar a si próprio. Privilegiar as conexões entre corpo, cérebro e emoção, elevar a carga emocional a partir do físico. Parte sempre do binômio ator-humano, considerando que deve buscar a atuação em tempo real e não a representação.

Irá utilizar o adjetivo refinado "para definir as qualidades das 'relações' entre o trabalho físico e o intelectual, entre o corpo e toda gama possível de elementos (desde os objetos até a música). Em um primeiro momento funciona como um indicador da aptidão, ou melhor, da habilidade resultante de conhecimentos adquiridos no trabalho com os 'materiais'. De novo recorremos ao sentido histórico do conceito e o termo 'material' liga-se ao conceito de techné, o qual, ainda não ligado às artes, indicava a atividade com materiais e uso de instrumentos. Disso é possível extrair o conceito de 'relação' que o ator meyerholdiano estabelecerá com os materiais; trata-se de uma nova relação, não de subordinação de um ao outro, mas da procura de equilíbrio, entendido enquanto organização consciente dos materiais"115.

É inaugurada assim uma discussão a partir da relevância dada ao corpo como um todo em cena. Neste sentido é preciso entender esse corpo em sua multiplicidade: enquanto matéria para a composição (o corpo em si), enquanto organizador do próprio material (o corpo autônomo em cena) e enquanto fundamento de um princípio ético (corpo deixa de ser "um corpo" para construir sua função cidadã). Este corpo fundamenta a filosofia ética e estética de Meyerhold.

A Professora Yedda, na dissertação de Mestrado mencionada, aborda de forma aprofundada e clara o ator meyerholdiano desde a seleção até a composição dos materiais. Para isso organiza seu trabalho em

\footnotetext{
${ }^{114}$ Idem ibidem, p. 43

${ }^{115}$ Idem ibidem, p. 44
} 
dois eixos: Os Princípios da Biomecânica, que revigoram a arte do ator e fundamentam suas relações, e a Unidade Mínima de Reação, com foco no comportamento ético e estético do ator.

Nossa intenção aqui é apenas apresentar sucintamente aquilo que é essencial para a compreensão da musicalidade no trabalho de Meyerhold a partir dos Princípios da Biomecânica e da Unidade Mínima de Reação, que poderão ser aprofundados com a leitura do trabalho mencionado. ${ }^{116}$

Para isso utilizaremos como base 0 trabalho da Professora Yedda, de uma forma muito reduzida e selecionada aqui, mas mantendo sua organização de ideias.

\section{Biomecânica}

Fundamento da Biomecânica: movendo-se a ponta do nariz, o corpo todo se move. Isso significa que à menor tensão o corpo todo reage. Não é tolerado nada de casual, o objetivo é desenvolver a máxima consciência do ator, com precisão.

Cada movimento é composto por pelo menos 3 momentos musicalmente concebidos: otkas, posil e tochka.

O otkas representa o início do movimento, sua preparação. Uma recusa ou negação do movimento que irá potencializá-lo. Pode ser compreendido, também, como um prólogo. Deve começar sempre no sentido oposto ao que será realizado. Quando vamos dar um tapa na cara de outra pessoa, nosso corpo projeta-se para o lado oposto ao da pessoa que receberá o tapa e nosso braço, para ganhar o movimento do tapa, também se lança, antes, no sentido contrário.

O posil é o movimento em si. O desenho da ação no espaço, o passeio do corpo durante um certo tempo para realizar a ação. É a expressão do que foi sugerido no prólogo. Seguindo o exemplo, é o movimento das mãos e braços, acompanhados do corpo, desde o extremo oposto até o toque no rosto. Tochka é a finalização, o acabamento. Corresponde ao

\footnotetext{
${ }^{116}$ A lista de Principios da Biomecânica, conforme organizado pela Professora Yedda, consta como Anexo D, neste trabalho
} 
epílogo. No entanto não tem a natureza de encerramento de uma ação, pois representa o momento preparatório do próximo movimento, ou ação. Seria o retirar a mão do rosto da pessoa que recebeu o tapa, retomar uma posição em preparação para outra ação.

Em alguns estudos são incluídos dois outros movimentos: tormos e rakursi. Rakursi é um movimento que da a ver outros planos, leva o ator para além do bidimensional, possibilita deslocar do olhar a partir das diversas possibilidades dos campos de visão do ator. Tormos consiste num movimento de suspensão, quando passados $50 \%$ do movimento que está sendo estudado, deve-se frear. Deve-se voltar pra algo que deixou.

Material

O material da arte do ator é seu próprio corpo, compreendido em sua totalidade e multiplicidade por mente, emoção e físico. Ao utilizar esse material não devemos partir da anatomia, mas da idoneidade do próprio corpo enquanto material para a interpretação. $O$ ator é portanto material e compositor deste material.

Meyerhold reforça a necessidade de um corpo bem treinado e do domínio das técnicas a serem utilizadas nesse material (para não ser dominado por elas). A partir do treinamento, o ator constrói uma vasta bagagem técnica, só então é possível dar carta branca ao que chamou de excitabilidade dos reflexos.

\section{$\underline{\text { Corpo }}$}

É fundamental tomar consciência de si mesmo no espaço, sob diferentes pontos de olhar. O movimento biomecânico no espaço cênico é uma semi-corrida ou uma semi-caminhada, sempre sobre as molas das pernas e pés.

Incentiva o estudo detalhado de cada parte do corpo, pois um movimento, por mínimo que seja, deve ressoar em todas as partes do 
corpo: "o movimento de uma única parte imediatamente organiza as interrelações inter-correntes entre as várias partes." 117

O ponto de partida são os movimentos fundamentais, ficando os mais refinados para após o domínio destes. Nesse sentido, reforça muito o trabalho dos membros superiores e inferiores a partir do centro de gravidade do sistema físico. Dando grande importância ao trabalho das mãos e das pernas, fontes de equilíbrio e desequilíbrio.

Interessante é perceber que também entende o trabalho sobre o corpo a partir do estudo do figurino e elementos de cena, já que interferem diretamente nas ações e, portanto, no jogo do ator.

\section{Olhos}

Entende que não se vê os olhos de um ator ruim, portanto deve-se treinar os olhos, concentrando o olhar sobre objetos ou pessoas, ensinando que se o olhar tende a se desviar de algo é a força de vontade que deve mantê-lo ali.

Fala também no estudo em manter o olhar na linha do horizonte, para que quando desviar de lá seu olhar, possa com essa ação trazer toda a atenção do público a si e significar o que quiser.

Para ele na ordem de importância vem primeiro os olhos, depois a boca, já que a articulação dos olhos é mais complexa que a dos lábios, também pelo fato de os lábios possuírem maior experiência em se articular.

\section{Equilíbrio}

Entende serem imprescindíveis a um trabalho de qualidade a calma imperturbável e o perfeito equilíbrio. "Cada um deve manter um equilíbrio convincente, uma reserva de atitudes, de poses e diversos rakursi que the permitam manter esse equilíbrio." ${ }^{118}$

\footnotetext{
${ }^{117}$ CHAVES. 2001. Op. cit. p. 51

${ }^{118}$ Idem ibidem, p. 54
} 
"Nos exercícios preparatórios, durante os ensaios, todas as emoções serão indicadas com leveza, limitando-se a indicar com precisão onde e quando deve acontecer a explosão. Uma emissão de voz mal preparada tecnicamente leva necessariamente à perda do equilíbrio. Então, necessita-se procurar novamente esse equilíbrio, ou seja, recomeçar o trabalho do início." 119

\section{Gesto - movimento - palavra}

A Biomecânica não incentiva que os atores "decorem" o texto, pois entende que relega à memória as falas. Sugere que o trabalho seja feito a partir da memória loci, ou seja, a partir das relações entre espaço e corpo em um tempo determinado.

Utilizando-se devidamente um ponto de apoio, os exercícios devem ser realizados a partir do otkas, posil e tochka, acentuando bem os momentos de início e fim. A emissão vocal, considerada como indicador do grau de reatividade, deve acontecer dentro das tensões estabelecidas.

Concentração e tenacidade são palavras de ordem para realizar um bom estudo biomecânico, já que o gesto nasce como resultado do trabalho de todo o corpo.

\section{Espaço}

O ator deve aprender a se orientar no espaço, em relação ao próprio espaço, aos elementos que o constituem e em relação aos outros atores. O trabalho de cada um é encontrar seus movimentos particulares, dentro da movimentação da massa. Isso deve se dar com precisão e rapidez.

\section{Tempo}

É trabalho do ator perceber o tempo sem calculá-lo. Quanto deve durar uma pausa ou uma fala deve ser resposta do ouvido e não do cérebro. Por isso é tão importante escutar-se em cena, quanto ver-se em cena.

${ }^{119}$ Idem ibidem, p. 54 
Os estudos devem aguçar a sensibilidade ao ritmo! $A$ tarefa aqui é perceber os ritmos não só com os ouvidos, mas com todo o corpo. As pausas também são muito importantes, pois elas abrem espaço para a interpretação, no entanto, devem ser pontuais. $O$ ator deve possuir um tempo de reatividade veloz.

"Para evitar que o ator se deixe levar pela anarquia, da dita 'interpretação interior', devemos nos impor um auto-controle em cena, como acontece nas partituras musicais, em que cada compasso é dividido por um travessão. Para cada compasso correspondem notas que podem ser cantadas, tocadas ou pausas de silêncio.

Devemos estudar as leis da música. No momento em que pronunciamos uma frase, somos compositores de uma melodia." ${ }^{120}$

\section{Economia}

Os estudos devem ser realizados com o menor número de técnicas possíveis, observando-se a economia nos movimentos.

\section{$\underline{\text { Reflexos }}$}

A excitabilidade dos reflexos compreende a reprodução, pelo ator, em sentimentos, movimentos e palavras, das tarefas que "recebe" do autor e do diretor, sempre realizados de acordo com o otkas, posil e tochka.

"A interpretação compreende a coordenação dos vários aspectos da excitabilidade dos reflexos. Os aspectos da excitabilidade dos reflexos constituem os elementos da interpretação do ator. Cada elemento da interpretação é formado por três momentos indispensáveis: 1. Intenção; 2. Realização; 3. Reação. A Intenção é a percepção intelectual de uma tarefa recebida externamente. A Realização é o ciclo dos reflexos de volição miméticos e vocais (o adjetivo mimético indica todos aqueles movimentos que surgem na periferia do corpo do ator, e também do ator no espaço). A Reação é a diminuição da vontade que foi satisfeita pela realização dos reflexos

${ }^{120}$ Idem ibidem, p. 58 
miméticos e vocais e coincide com a preparação de uma nova intenção." ${ }^{121}$

A excitabilidade dos reflexos é, para Meyerhold, o oposto do temperamento, pois resulta de um bom treinamento.

\section{Pré-jogo ou Pré-interpretação}

A Pré-interpretação consiste nas ações do ator que preparam o público para se conectar à situação cênica, de forma que não irá realizar qualquer esforço para receber todos os detalhes da cena. $O$ trabalho do ator é alternar a interpretação e a pré-interpretação.

\section{Reserva}

$\mathrm{Na}$ atuação e nos estudos o ator deve desenvolver uma capacidade de utilizar todos os recursos de que dispõe sem se consumir totalmente. Se o ator emprega muita energia já no início do trabalho, certamente não conseguirá concluí-lo sem comprometê-lo. É preciso dar o máximo de si em cada momento, mas tomando o cuidado de sempre possuir uma reserva que possibilite ao trabalho, que já parece estar no máximo, ir além.

"Piano e forte são sempre relativos. O público deve sempre ter uma impressão de uma reserva inutilizada. Em nenhum momento o ator deve gastar toda provisão de materiais que possui. Mesmo o gesto mais amplo deve deixar a possibilidade de algo ainda mais amplo."122

\section{Público}

"A peculiaridade da arte do ator - e que o diferencia do escritor, do diretor e de outros artistas - reside no fato que o processo criativo acontece diante dos espectadores. Consequentemente, $\mathrm{o}$ ator

\footnotetext{
${ }^{121}$ Idem ibidem, p. 59

122 Idem ibidem, p. 62
} 
se encontra em uma espécie de interdependência com o espectador, e este último assume o papel de caixa de ressonância viva e pronta para reagir a todas as manifestações de habilidade do ator. $O$ ator, por sua vez atento em seguir a caixa de ressonância (o público), através do seu fino ouvido, reage instantaneamente, por meio de improvisação, a todas as exigências que emergem. Graças a uma série de sinais (barulhos, movimentos, golpe de tosse, risadas), 0 ator deve individualizar com segurança o comportamento do espectador diante do espetáculo." 123

O trabalho sobre os Princípio da Biomecânica são capazes de conduzir o ator a um trabalho plástico e rítmico, que conecta corpo, mente e emoção a partir da musicalidade de cada um e do próprio movimento. É um movimento que liberta do trabalho com a memória emotiva e da busca da emoção como objetivo da atuação, pois propõe uma partitura que faz o ator agir para sentir e fazer sentir. Não cria imersão, mas explosão, já que lança ao ator a tarefa de ser capaz de possuir um olhar múltiplo, um para si, outro para os demais atores, outro para os demais artistas criadores, outro para o espaço e, ainda, outro para o público, destino de seu trabalho e a quem deve emocionar.

A biomecânica não cria exercícios para serem levados à cena, mas para serem estudados, aprofundados, encarnados e, a seguir, superados. Tais exercícios, por despertar no ator a consciência de sua movimentação espaço-temporal, desenvolvem nele a musicalidade, conforme falaremos mais nas considerações finais desse trabalho.

\section{Unidade Mínima de Relação}

Finalmente nos resta abordar este eixo do trabalho meyerholdiano, que foca as relações do ator e todos aparatos expressivos com que pode contar/jogar.

${ }^{123}$ Idem ibidem, p. 65 
A Professora Yedda estruturou este termo a partir da posição central que o ator ocupa nas propostas de Meyerhold, considerando que "revelam a engrenagem do comportamento cênico do ator e das pesquisas que the dão suporte."124

A partir disso, o ator é gerador das seguintes Unidades Mínimas de Relações:

a) $\mathrm{O}$ ator e o pensamento - movimento - emoção palavra

b) $\mathrm{O}$ ator e o ritmo;

c) $O$ ator e o animal;

d) $\mathrm{O}$ ator e o espelho;

e) $\mathrm{O}$ ator e a personagem;

f) $O$ ator a o teatro de convenção;

g) $\mathrm{O}$ ator e os teatros orientais;

h) O ator e o público;

Entendendo que a interpretação de uma obra deve ser sistemática, levando em conta todos os princípios e fontes que a compõem, é de grande importância conhecer globalmente a obra de Meyerhold para poder compreendê-la nas partes. No entanto, não iremos aqui nos deter à análise dos tópicos referentes à Unidade Mínima de Relação, mas fazer um apanhado geral das ideias mais importantes para a compreensão da musicalidade no trabalho do ator.

Um ponto já bem detalhado, mas que merece ser visto é a relação ator e ritmo. Em seu teatro Meyerhold faz os movimentos antecederem as palavras, mas dá muita atenção ao estudo da prosa e da poesia, utilizando leituras de dramas musicais e o estudo da métrica.

O suporte musical dá as palavras o caráter de harmônicos, o que as garante presença espacial e cadência temporal. "O ritmo

${ }^{124}$ Idem ibidem, p. 69 
como base do movimento. A música é sempre o canovaccio ${ }^{125}$ do movimento, seja a música reproduzida por instrumentos, seja a música cantarolada pelo próprio ator durante a execução dos seus movimentos." ${ }^{126}$

Explora diversas possibilidades de relação com a música para o corpo do ator e para o corpo da cena. Desde arranjos e sonoplastia em diálogo com as falas ou os movimentos dos atores, até a utilização de danças e exercícios rítmicos, além de incentivar os acentos e pausas, sempre com vistas a encontrar possibilidades de polifonias.

Finalmente, na relação do ator com a personagem, busca sempre valorizar a presença daquele. A inteligência e personalidade do ator é que são capazes de preencher a personagem e criar o jogo cênico. Não imagina um ator que não se posicione diante do mundo e, como consequência, traga esse posicionamento para a personagem, pois ao revelar a personagem ao público, está também revelando a si próprio e, somente assim, pode criar o duplo jogo que lhe cabe.

“(...) $\mathrm{O}$ ator em cena vive através de um mundo duplo, em dois mundos: no mundo da personagem, o qual foi construído por ele, e no mundo do próprio eu. $\mathrm{O}$ ator é o administrador, o organizador, às vezes aventureiro, às vezes tribuno, ele sabe como administrar o todo para obter um determinado efeito. (...) Hoje ele interpreta um selvagem, amanhã salta do teto, daqui dois dias faz um fascista. Se o cérebro do ator não participasse, o público não se sentiria próximo ao ator, nem por um momento sequer, assim como não poderia sentir-se próximo de um violinista preocupado somente em alcançar níveis de virtuosismo movimentando os dedos sobre o violino."127

\footnotetext{
${ }^{125}$ Termo originário da Commedia del'Arte que significa um roteiro de ações que serve como base para o jogo cênico dos atores.

${ }^{126}$ MEYERHOLD, V. E. O amor das três laranjas. N. 1 (1914) apud THAIS. 2009. op. cit. p, 386

${ }^{127}$ MEYERHOLD, V. E. Conferência de Meyerhold sobre o Sistema e os Modelos de Interpretação do Ator, 1925. in PICON-VALLIN, Béatrice. Meyerhold, Les Voies de La Crèation Thèátral, n. 17. Paris: Editions Du CNRS, 1990, p.93
} 


\subsection{A musicalidade na pedagogia meyerholdiana}

\subsubsection{Situando o leitor}

Em sua busca por um novo teatro e por um novo ator, Meyerhold desenvolveu alguns métodos de trabalho, utilizando a musicalidade como eixo da investigação e da composição cênica. Isto pode ser percebido de forma objetiva, quando fala em ritmo, pausas, composição, mas também intrinsecamente, nos princípios da Biomecânica, na plasticidade do movimento ou no que chamou de "teatro em linha reta".

A maior parte desse material já foi levantado nos tópicos anteriores, portanto iremos, agora, realizar um passeio, que esperamos suficientemente inspirador, sobre os rastros deixados pelo mestre russo em relação à sua pedagogia e encenação trabalhando musicalidade.

A primeira questão que surge é a referente ao tempo. "Não é na capacidade de refletir a plenitude da realidade, ou, dito de outra maneira, das representações e de suas transformações no tempo, que reside a arte. Ela decompõe o real utilizando tanto as formas espaciais quanto as formas temporais." ${ }^{128}$

Appia, que anteriormente realizou largas empreitadas musicais no teatro, já fazia referência às artes do tempo e às artes do espaço, com uma clara divisão entre elas. No mesmo vetor, mas em direção distinta, Meyerhold entende o teatro como arte do TEMPO e do ESPAÇO, acentuando a questão da espacialidade do teatro no tempo.

Promove assim um deslocamento no sistema stanislavskiano, que detinha-se mais às questões do tempo, criando na relação tempo-espaço novas bases para a composição cênica.

Utiliza, primeiramente, como já dissemos, o grotesco para trilhar este percurso. É a partir da revelação aprofundada exatamente nos pontos mais obscuros do homem e seu cotidiano, que encontra uma musicalidade capaz de deslocar a plateia para o estado da arte, da música.

${ }^{128}$ MEYERHOLD. Do Teatro. Apud THAIS. 2009, op. cit. p. 343 
Mas é também um estudioso e apaixonado pelo teatro oriental, altamente codificado em desenhos e sonoridades musicalizadas. Ao analisar uma cena em que um "japonês entrega uma flor à sua amada", afirma: "Não estaria o corpo, com suas linhas e seus movimentos harmônicos cantando por si mesmo, tal como os sons?"129.

Em sua brilhante visão de ator e encenador, chega à conclusão de que a resposta será afirmativa sempre que no embate entre forma e conteúdo, aquela seja privilegiada, tornando-se a alma da cena.

Era a partir dessa ideia que realizava todo o trabalho de partitura das ações (físicas e vocais) no corpo do ator. Na busca de um corpo que, invariavelmente, emane música e que, consciente disso, possa compor movimentos individuais e coletivos capazes de, pela musicalidade, conectar a emoção daqueles que assistem ao espetáculo.

A música e o teatro convergem em sua prática teatral como decorrência de sua vivência e investigação. Possui profundo conhecimento em música, era violinista com conhecimento suficiente para ser regente de orquestras, entregando-se à pesquisa da ópera por muito tempo. Realiza, também, estudos aprofundados a partir do teatro de variedades, do Teatro Oriental e do Balagan, parte disso já foi abordada neste trabalho.

No estudo sobre ópera, dedica-se à prática e à teoria a partir de investigações, leituras e diálogos com Appia, Craig, Fuchs, Wagner e Hagermann, para compreender melhor as especificidades do teatro de convenção, um teatro onde a música é uma substância da ação. Toda a criação tem como disparador partituras e ritmos bem definidos, ainda que mutáveis ao longo do processo.

Em suas formulações para um novo teatro, conta ainda com a influência dos estudos realizados por Frederik Winslow Taylor juntamente com os visionários da administração industrial Frank e Lilian Gilbreath e, principalmente, das pesquisas desenvolvidas por Ivan Pavlov.

Vale observar que as teorias de Dalcroze, juntamente com as práticas de dança de Isadora Duncan, após serem amplamente

${ }^{129}$ MEYERHOLD, V. E. Do Teatro. 2012, op. cit, p. 216 
experimentadas em seus cursos, são veementemente recusadas pelo mestre russo a partir de 1917, por entendê-las como uma repetição simétrica, sempre reforçando a mesma música, portanto, incapazes de ultrapassar a musicalidade cotidiana. Buscava, primordialmente, a polifonia.

No oriente, Meyerhold encontra forte respaldo de musicalidade para o trabalho cênico. Neste teatro, as falas e os movimentos são marcadamente estruturados a partir de uma forte noção musical. E é essa música que é capaz de revelar a multiplicidade na ação cênica, organizando o trabalho de todos os envolvidos na criação. Obviamente, estamos falando de um teatro fundado em valores e conceitos diferentes dos aristotélicos e, por isso mesmo, capaz de nos revelar outras possibilidades do fazer teatral. Sua natureza precisamente codificada exige dos atores um profundo conhecimento do fenômeno teatral como um todo, para que possam dominar a espacialidade no tempo correto.

Essa relação entre o tempo e o espaço será uma constante nas práticas meyerholdianas, constituindo uma das essências no trabalho do ator com a musicalidade. Compreender essa relação é conectar-se com o jogo cênico e com o público no tempo e no espaço precisos. Sem racionalizações, uma vez que a compreensão se dá na duração, na altura, no ritmo, nas dissonâncias etc., produzindo um resultado concreto no aqui, o lugar dos acontecimentos.

Toda essa gama de influências, aliada à sua vivencia como ator de Stanislaviski e toda sua prática enquanto encenador e formador teatral, leva-o ao desenvolvimento de um jogo cênico pautado na música, em seus princípios e suas possibilidades. 


\subsubsection{A prática musical em Meyerhold}

"Eu trabalho dez vezes mais facilmente com um ator que ama música. É preciso habituar os atores à música desde a escola. Todos ficam contentes quando se utiliza uma música 'para a atmosfera', mas raros são os que compreendem que a música é o melhor organizador do tempo em um espetáculo. O jogo do ator é, para falar de maneira figurada, seu duelo com o tempo. E aqui, a música é sua melhor aliada. Ela pode não ser ouvida, mas deve se fazer sentir. Sonho com um espetáculo ensaiado sobre uma música e representado sem música. Sem ela, - e com ela: pois no espetáculo, seus ritmos serão organizados de acordo com suas leis e cada intérprete a carregará em si." ${ }^{130}$

Meyerhold tinha consciência de que uma das bases de seu trabalho enquanto encenador e preparador de atores era sua educação musical. A música sempre foi, na sua prática, muito mais que um fundo ou acompanhamento, mas a "grade de interpretação de uma dramaturgia, um ponto de apoio para a composição cênica, um meio de triunfar sobre o naturalismo, uma vez que coloca em cena um ritmo que rompe com o mundo cotidiano."131

Beatrice Piccon-Vallin escreve que mesmo em suas montagens consideradas "clássicas" ${ }^{132}$ a música penetra o teatro, tanto como material quanto como princípio organizador da ação cênica. O jogo do ator e a percepção dinâmica de público são integralmente fundados na musicalidade como essas conexões se apresentam. Há uma base para o trabalho que não se perde, não se confunde, nem limita, mas guia, inspira e provoca o ator em estabelecer essas relações, e essa base é sempre musical.

\footnotetext{
130 A. Gladkov, "Meyerhold fala", Notas dos anos 34-39, O Teatro, Moscou: Iskusstvo, 1980, p. 282. Apud PICON-VALLIN, B. Le jeu de l'actor chez Meyerhold et Vakhtangov, Laboratoires d'études theatrales de l'Université de Haute Bretagne, Études \& Documents, T. III, Paris, 1989, p s. 35-56. Tradução de Roberto Mallet.

${ }^{131}$ PICON-VALLIN, Béatrice. A Música no jogo do Ator Meyerholdiano. IN In Le jeu de l'acteur chez Meyerhold et Vakhtangov. Paris: Laboratoires d'études théâtrales de l'Université de Haute Bretagne. 1989. Tradução de Roberto Mallet.

132 Refere-se a "O Inspetor Geral”, “A Desgraça de ter espírito” e “ A Dama das Camélias"
} 
No mesmo texto, ela afirma que a música, a partir da grande importância que the é dada nos círculos simbolistas que Meyerhold frequentou no início do século XX, vai impregnar progressivamente seus modos de criação e tornar-se uma figura constante de sua produção teatral.

"Na montagem de $A$ Morte de Tintagiles, encontramos os primeiros escritos das teses desenvolvidas para orientar 0 ator. Meyerhold apresenta alguns princípios básicos:

- Vivência da forma: mecanismo de fixação e de controle da instabilidade emocional, livrando o ator dos fatores causais da interpretação;

- $\quad$ Sorriso, tremor exterior e tranquilidade épica: eliminam o excesso de reações externas, traduzindo uma atitude de calma e contemplação;

- Dureza do som e ausência de vibrações: manifestavam o cuidado com a estrutura rítmica do texto;

- Pausa: não se destina a potencializar o estado de espírito, mas, acima de tudo, destina-se à construção intelectual." ${ }^{133}$

É evidente que se trata de elementos musicais na formação do ator. Aponta bases como o silêncio, quando traz a noção de imobilidade e, mais precisamente, promove uma investigação sonora ao trabalhar a dureza do som e as pausas.

Isso mostra que, desde o início de suas pesquisas, compreende a atuação a partir de princípios musicais, sempre friccionados aos teatrais, mas principalmente encarados como artísticos, por servirem a qualquer linguagem. $O$ que nos leva a refletir a partir da ideia de que a arte também foi "tecida junta" em sua ancestralidade e que isso não deveria ter sido desprezado pelas práticas que levaram à sua segmentação.

É neste sentido que podemos observar musicalidade nos desenhos plásticos e teatralidade no ritmo. Enfim, há no tratamento musical que Meyerhold emprega, um olhar artístico anterior ao olhar teatral ou musical

${ }^{133}$ THAIS. 2009. op. cit. p. 28 
(no sentido disjuntivo). Isso fica claro em vários de seus relatos, pois não separa sequer a terminologia em teatral, musical ou das artes plásticas. Ao contrário, as utiliza para fazer arte, como se compreendesse que a multiplicidade humana se revela em prismas dessas artes, mas conecta-se sempre no homem e a partir dele.

"Em seu 'Tristão e Isolda', os grupos ou as unidades esculturais formadas pelos atores animam-se musicalmente, passando da imobilidade a movimentos rápidos, e mesmo à corrida (como um pouco mais tarde, em 1911, na encenação de 'Orfeu' de Gluck). O ator submete-se ao desenho tônico da partitura para realizar um desenho plástico simples, claro, concentrado, baseado sobre um princípio de economia, capaz mesmo de definir um traço esboçado pela orquestra, e até de completar a partitura, e portanto de introduzir uma espécie de diálogo com ela. Meyerhold busca no jogo de seu ator um ritmo de movimentos 'rigorosamente sincronizado com o da música', 'uma concordância rítmica', sem todavia que este jogo ilustre a música, mas a revele e complete." ${ }^{134}$

Não é apenas pela musicalização da cena e da atuação em Meyerhold, que ele é uma referência nesse sentido, mas principalmente pela inteligência com que o faz. Sua busca formal é amplamente fundada em princípios, já elencados aqui, que dão substancia a este trabalho.

Mas vamos lançar nossos cinco sentidos sobre a experiência musical que ele propõe.

O estudo de Meyerhold percorre movimentos bem delineados. Parece primeiramente buscar unir movimento e ritmo, pensando já em entonações e pausas, mas também no aprofundamento melódico deste movimento, no corpo e mente do ator. A concordância entre a sonoridade e o desenho produzido busca aprofundar a consciência sobre a relação entre música e expressão corporal.

Num movimento seguinte, passa a provocar a polifonia entre os deslocamentos do ator no espaço e os movimentos estáticos de seu jogo. Há um treino voltado para o ator, com vistas a muni-lo de recursos que

${ }^{134}$ PICON-VALLIN. 2008. op. cit. p. 2 
serão acionados, conforme a necessidade, no próximo momento, quando de seu jogo com o outro, com o espaço e com o público. Em ambos momentos a música e o movimento manifestam um gênero de polifonia.

"Os atores, sem dar ao espectador a construção da música e dos movimentos em um cálculo métrico do tempo, procuram tecer uma rede rítmica". É, formulado claramente, um primeiro esboço da teoria meyerholdiana do contraponto, fundamentando as leis cênicas do movimento do ator no tempo e no espaço. ${ }^{135}$

Essa ideia de contraponto é executada de forma mais intensa em 1935, com "A Dama de Espadas", de Puchkin-Tchaikoviski. Ali, segundo a crítica e artigos, temos um exemplo claro de "ator autenticamente musical, conservando exteriormente a liberdade de seu comportamento teatral, mas de fato ligado à música durante todo o tempo em um complexo contraponto rítmico. Seus movimentos podem ser invertidos em relação ao metro da música, acelerados ou ralentados; entretanto, mesmo sua pausa estática sobre o fundo de um movimento rápido da orquestra e, digamos, um gestual rápido sobre o fundo de uma pausa geral na música devem estar estritamente apoiados sobre a partitura da encenação, concebida como o contraponto cênico da partitura do compositor". A crítica musical vai, portanto, no mesmo sentido que Meyerhold e afirma: "Esforçamo-nos em evitar fazer coincidir o tecido musical e o tecido cênico sobre a base do metro. Aspiramos à fusão contrapontística dos dois tecidos, musical e cênico" ${ }^{136}$.

A proposta é que o ator, ao mesmo tempo, siga a música e se oponha a ela para obter efeitos mais poderosos em relação ao público, por trabalhar diretamente com as musicalidades presentes, no palco e na plateia.

Sem deixar de dar a devida importância às diversas possibilidades de utilização da música num espetáculo, a preocupação de Meyerhold é para além das escolhas de trilhas ou das acentuações musicais,

\footnotetext{
135 Idem ibidem

${ }^{136}$ SOLLERTINSKI, I. Meyerhold e o Teatro Musical, A Dama de Espadas. Reunião de artigos. Leningrado: 1935, p. 41 apud PICON-VALLIN. 2008. op. cit. p. 3
} 
já que esta tarefa parece olhar mais para a burguesia e para a elite intelectual, que frequentam as salas de teatro da época. Sua atenção vai, também, para a organização sonora do espetáculo. Ali deve haver uma composição coletiva entre todos os artistas envolvidos na cena, suscitando no público a maior diversidade possível de associações.

Assim, a música, além de ordenar o jogo do ator, pelas questões de tempo, ritmo e entonações, é capaz de possibilitar uma percepção não cotidiana da obra teatral, portanto, mais artística e criativa.

Dessa forma, preenchia musicalmente de forma tão completa suas obras, promovendo um entrelaçamento de falas, réplicas, movimentos, músicas, ações, e organizando a complexidade da criação do espetáculo a partir da música, que Turovskaia, observou: "os espetáculos de Meyerhold eram para o teatro o que os versos são para a prosa: nenhum tempo vazio"137

Mas suas propostas com musicalidade são notáveis também do ponto de vista do ator. Este trabalho não fica restrito à movimentação cênica. Há uma compreensão de corpo em seu todo, de forma global. Nesse sentido, desenvolve diversos estudos aliando também a palavra à música.

A esse propósito, numa das investigações, cria um princípio de leitura musical a partir de "Antígona", de Sófocles, na qual, em colaboração com o compositor Gnessin, com quem trabalhava, elabora uma partitura de música onde insere o texto, de forma que seus atores possam experimentar criar a partir das restrições musicais. Depois de incorporadas as falas "musicais", os atores as associam a um trabalho plástico de movimento. Conforme aprofundava seus estudos, criava métodos mais sofisticados, contando com atores musicalmente cada vez melhor preparados.

"O processo de "musicalização" toca todos os domínios do teatro. E logo de início o trabalho dramatúrgico. A composição dos scenarii de encenação de Meyerhold, onde a música real tanto pode estar ausente quanto pode estar presente, segue as leis da forma-

${ }^{137}$ PICON-VALLIN. 2008. op. cit. p. 3 (Refere-se ao espetáculo "Bubu”) 
sonata, uma parte lenta intercalada entre duas partes rápidas. O melhor exemplo deste trabalho é 'A Dama das camélias' cujos cinco atos são divididos em episódios, todos designados por um termo musical que Ihes dá o colorido, o ritmo, a velocidade. Um exemplo:

Capriccioso

$I^{\circ}$ ato, $2^{\mathrm{a}}$ parte

Lento

Scherzando

Largo e maestoso

Meyerhold busca colocar na obra a representar uma dramaturgia musical com introdução, exposição do tema principal, aparição de temas secundários, desenvolvimento, repetição do tema principal, culminação, final, com mudanças de ritmos, rallentandi geradores de tensões (neste exemplo, lento, rallentando, scherzando, culminação). Reencontramos este processo no trabalho de encenação: "em música", diz Meyerhold a seus estudantes, "há uma acumulação de acordes de sétima que o compositor introduz conscientemente e que por muito tempo, muito tempo, não se resolvem na tônica (...). Há a alternância de momentos estáticos e de momentos dinâmicos, seguida de equilíbrios e desequilíbrios... Estou a ponto de dar a resolução de uma cena, mas, conscientemente, não a resolvo, ponho mesmo obstáculos a esta resolução e depois, no fim, a permito"138

A música é uma espécie de elo que mantém vivas e em constante fricção todas as partes da obra teatral. É sempre presente a conexão entre ao menos quatro elementos: o trabalho do ator, o texto, as provocações do encenador e o público. Tem a consciência de que a ressonância no público virá das ações estabelecidas no jogo do ator, por esse motivo o instiga a habitar a improvisação, sempre com propostas claras do encenador e do texto.

Em sua busca por um novo ator, Meyerhold, passa por um período construtivista, onde o desnuda e o demaquila, desvendando seus músculos, ossos e cérebro, colocando tudo em jogo cênico. Passa a ver a arte

${ }^{138}$ Idem ibidem. p. 4 
como um trabalho que impõe precisão e rigor. Nesse ponto, a música também tem muito a colaborar e, por isso mesmo, tem um papel primordial em todos os cursos que passa a oferecer.

Para ele, o ator deve distribuir seus movimentos, corpóreos e sonoros, sobre a música. Viver nela, ocupá-la, tomá-la para si e dá-la ao movimento, sempre sem ilustrá-la. Este é o princípio do movimento biomecânico, que se constrói a partir de uma frase musical.

Há uma necessidade concreta da presença da música em seu trabalho, notadamente enquanto organizadora das complexidades que envolvem a atuação e as relações na composição da encenação. A música, como parte obrigatória do trabalho, passa por um processo de encarnação no ator. Pela abundância de sua presença, promove, ainda, um alargamento de repertório musical. Consequentemente, os repertórios corpóreos (corpo, voz e cérebro) também ganham em possibilidades.

A propósito dos procedimentos com música aos seus atores, Meyerhold disse no curso de 19 de novembro de 1921 para estudantes do GVYRM $^{139}$ :

"Faço meus alunos trabalharem sobre um fundo musical, não para colocar a música em cena, mas para que se habituem ao cálculo do tempo, para que se apoiem nele. Vocês me perguntam: não seria possível, em lugar da música, utilizar simplesmente um metrônomo? Não, não é o suficiente. $O$ metrônomo desempenha o mesmo papel daqueles que batem em pequenas tábuas como se faz no teatro japonês com o objetivo de criar um fundo para a representação. Mas isto não nos satisfaz, nós que pertencemos a uma outra cultura; isto resulta tedioso para nós. Sobre um roteiro métrico, temos necessidade de um fundo rítmico. Pude observar como vocês distinguiam as dissonâncias e as consonâncias. Percebo que em 1921 é consonância aquilo que, no século XIX, soava ainda como dissonância. Mais ainda, aquilo que, apenas há dez anos, parecia dissonância é agora percebido como consonância. Quando toquei um acorde de Scriabin, notei com alegria que ele suscitava um sorriso agradável. Vivemos agora em uma

\footnotetext{
${ }^{139}$ GVYRM é a sigla para Laboratório Superior de Direção do Estado, da U.R.S.S.
} 
cultura tal que se pode tocar um acorde de Scriabin e suscitar um sentimento de prazer, embora ele não seja construído de acordo com as regras acadêmicas.

Isto significa que é melhor fazer estes exercícios sobre um fundo de muito boa música e, além disso, imediatamente acostumar os atores a traduzir a música na linguagem do movimento, tanto métrica quanto ritmicamente, habituá-los a construir uma partitura de movimentos que corresponda à partitura musical.

No circo, quando o acrobata trabalha em seu trapézio, tudo é realizado a partir de um cálculo extraordinário, o menor desvio em relação a este cálculo leva ao fracasso. Há uma diferença colossal no trabalho do acrobata segundo a música esteja ou não presente: quando a música não toca, o acrobata tem mais chances de cair. (...)

Ele tem necessidade de um fundo sobre o qual apoiar-se solidamente. Isto significa que existe uma precisão rítmica, mas não precisão musical. Ele é livre em seus movimentos e pode pegar o trapézio, soltá-lo e saltar quando quiser. Não o lança necessariamente em um tempo forte, pois não trabalha metricamente, mas ritmicamente. Se pudéssemos registrar seus movimentos em um aparelho perfeito, obteríamos resultados espantosos. Costumo explicar o ritmo como qualquer coisa que luta contra, que se opõe à monotonia do metro. Portanto, um acrobata que trabalha no trapézio não utiliza os tons fortes e fracos, mas constrói a música de seus movimentos de tal forma que ela seja uma segunda partitura que, se fosse escrita com precisão, coincidiria totalmente ritmicamente, ou seja, criaria uma co-ritmia.

Como traduzir isto na linguagem do ator? Se vocês criarem o hábito, em seus exercícios, de relacionar-se com um fundo musical, afinarão seus ouvidos de tal maneira que acontecerá a mesma coisa que ontem, quando os tempos de silêncio, de um exercício para outro, eram retidos em seus ouvidos como uma espécie de fluxo rítmico e vocês sentiam as pulsações musicais. 
Primeiro, há resistência: vocês imaginam, cantarolam, e depois são carregados como por uma onda na música. Se além disso balançarem-se, encontrarão ainda mais facilmente. Quando visitei em Constantinopla uma escola corânica observei o seguinte: o mestre lia um texto do qual o aluno deveria se lembrar. Ele segurava o rapazinho pela manga e, na mão esquerda, tinha o livro. Lia o texto e o rapazinho repetia depois dele, e ambos balançavam-se. Neste contexto, a memorização se fazia mais racionalmente, melhor que sem o balanço. A memorização baseava-se sobre o fato de se estabelecer assim um ritmo do texto, e de que este ritmo era mais bem percebido com a presença do balanço. Quando o ator trabalha sobre um papel, qualquer que ele seja, depois de se ter acostumado no contexto-laboratório do Estúdio a trabalhar sobre um fundo musical, terá sempre o hábito de prestar atenção no tempo, mesmo se a música estiver ausente". ${ }^{140}$

Finalmente, cabe agregar mais um elemento de suma importância para Meyerhold, retirado de seus estudos e experiências com teatro oriental, a pausa. Para ele, é fundamental compreender o que significa a pausa no trabalho do ator. Não é a ausência, nem a interrupção, mas é a expectativa da continuidade, já que contém em si o elemento primordial do movimento. Assim, propõe a escuta do silêncio, como exercício para que o ator compreenda tudo o que ele contém.

É essencial despertar a musicalidade, a presença da música no corpo-mente-emoção do ator. A composição musical das estruturas da encenação permitem que o ator domine o tempo teatral de forma precisa e, assim, se oriente melhor no espaço cênico, se emancipando para jogar com ele no tempo.

$\overline{{ }^{140} \text { MEYERHOLD, V. E. Apud PICON-VALLIN, Béatrice. Op. cit. p. } 6}$ 


\subsubsection{Um Teatro Musical}

Enquanto formador de atores e de encenadores, Meyerhold buscou, incansavelmente, a penetração musical nas matérias dos cursos que formulou ou participou. Sempre que pode, inclusive, criou eixos de estudos comuns entre atores e músicos, incluindo o estudo de solfejo, piano, canto, diç̧ão, teoria elementar (da música e do teatro), teoria da forma, harmonia e contraponto.

Num dos programas de seus cursos no GVYTM encontramos uma série de exercícios estabelecidos para desenvolver as acuidades auditivas e visuais dos futuros encenadores e atores. Para isso, desenvolvia trabalhos como: reconhecimento rápido dos ritmos, valor dos intervalos de tempo (curtos e médios), sensibilidade aos movimentos acelerados e ralentados, medida das variações de som em altura, tonalidade e força, identificação de nuances de luz e cor, avaliação de distancias entre outros.

O jogo musical manifestado na obra de Meyerhold foi organizado por Picon-Vallin (1989) em cinco exemplos, que resumimos aqui:

a) Construção do jogo sobre o princípio do leitmotiv: trata-se da repetição de um fragmento de jogo, de uma atitude, em diferentes contextos, acompanhada ou não de música, jamais é uma simples repetição, mas o aprofundamento do tema. Pode surgir como um "motivo pantomímico" ou uma fala, por exemplo.

b) $\underline{O}$ jogo sobre o tempo, com ou sem música: trabalha as relações de ritmo em fragmentos de tempo, com durações diferentes, combinando-se entre si, utilizando a pantomima apenas como material secundário, que constitui o jogo, que suscita a emoção no espectador. Por exemplo, o intérprete de um papel, para criar mal-estar, angústia, passa de um movimento brusco, que introduz uma primeira fase de jogo, a uma reação lenta, imóvel, a qual se prolonga com as ações seguintes. Os fragmentos temporais são materializados pelos 
fragmentos de jogo, mas é a combinação das durações que cria o impacto, e este é o principal significante.

c) Jogo construído diretamente sobre uma música: o intérprete de um papel, por exemplo, joga com o pianista. Este se detém o tempo necessário para que ele diga uma palavra que deve ser posta em relevo, canta uma frase de seu texto, marca o ritmo com algum elemento de cena, ou outras ações nesse sentido. Procura criar um tecido de relações entre a música e as personagens, destinado a complicar um material dramatúrgico muito simples e unívoco. O ator precisa utilizar-se bem dos acentos e das suspensões, compondo alterações na melodia de suas personagens.

d) Jogo sobre o jazz. Por intermédio do poeta V. Parnakh, voltando de Paris para Moscou em 1922, trazendo instrumentos e partituras de jazz, este tipo de música fez sua entrada na URSS sobre a cena do Teatro Meyerhold na segunda temporada de "O Corno Magnífico", depois em outros espetáculos. Assim, o teatro tem à sua disposição, com o jazz, uma nova música onde o som e o gesto estão ligados, na mímica do rosto e do corpo do instrumentista que frequentemente acompanha seu desempenho com exclamações. Aqui, podemos destacar a intenção em jogar com o "novo". O ator em suas ações físicas e vocais pode compor uma partitura real e uma música "imaginária", feita do ritmo dos seus movimentos, da combinação da altura e da duração das réplicas, isso garantirá que nenhum ator tenha uma voz "cotidiana" . A outra novidade para a época está na união do movimento e da palavra, movimento que informa, torna rítmica a palavra, e comunica ao espectador o conteúdo emocional do jogo não por estados de alma, mas por uma "transmissão puramente musical, dinâmica e rítmica" . O que mais interessa a Meyerhold é o "estado de jazz" ou o "estado de orquestra".

e) A dança. Em todos os espetáculos de Meyerhold, encontramos a dança, que aliás é ensinada nos ateliês em igualdade de condições com a biomecânica. A dança é ao mesmo tempo uma técnica e um tema, o do "baile", diversão social coletiva e representação de uma época, como nas quadrilhas do "Baile de máscaras" (1917) ou de "O Inspetor Geral" (1926). É 
também um meio de exprimir um estado psico-fisiológico pelo qual as emoções se revelam em um gestual mudo, com uma força intensa.

"...a afirmação de Fuchs de que o teatro se origina da dança, reaproxima uma tradição técnica até então esquecida e prenuncia os jogos de cenas "dançantes", que Meyerhold desenvolveria posteriormente, e os estudos futuros da pantomima cênica. E, finalmente, Fuchs considera o ritmo como o princípio da expressão do ator.

Esse é um aspecto fundamental para o teatro meyerholdiano, pois o modelo musical foi uma das bases da sua composição teatral." ${ }^{141}$

Em sua compreensão do ofício do ator, o coloca como um improvisador que, para não permitir que o espetáculo se perca, alongandose ou reduzindo-se em intervenções perdidas, deve respeitar a composição sobre a qual está assentado. É na precisão rítmica, de duração e de altura que estão as bases para um bom ator fruir em cena. E reforça que, o ator, enquanto instrumento de música, deve saber jogar em solo, duo, trio, ou num jogo coletivo, em orquestra, onde cada um está atento a todos os outros.

"Por isso o ator deve rever absolutamente os seus métodos de interpretação. Sem a música a interpretação torna-se mais fácil. Por quê? Porque falta o movimento musical. Isto é, eu me preocupo somente com o figurino, com os detalhes da interpretação. Mas se entra a música, vá até o fundo, abra as janelas, rompa os vidros, deixe que esta música invada a cena e se faça ouvir, porque este novo elemento deve ter seu próprio posto. Infelizmente Sada Yacco morreu. Uma outra representante da escola Ganako, era Hanako. Em um monólogo, Hanako precisava exprimir o sentimento de exaltação, pois estavam para acontecer coisas importantes, ela começou a interpretar com ardor. Mas por mais que fizesse, era insuficiente; recorria também a gestos, e a todos os meios, mas não bastava. O que fez então? Elevou ao máximo a sua exaltação e começou a se mover com o ritmo da música. E assim conquistou o público.

${ }^{141}$ THAIS. 2009. op cit. 28-29 
Não com as palavras, nem com a mímica, nem com outros estratagemas, mas somente quando ela fundiu a sua interpretação com a orquestra." 142

Se podemos chamar o ator meyerholdiano de musical, exatamente pelas dissonâncias e consonâncias encontradas entre teatro, musica e todas as outras linguagens artísticas friccionadas em sua formação e no seu trabalho cênico, todo seu pensamento artístico e pedagógico só poderia resultar numa prática em torno de um teatro que desse conta de todo esse material com a devida profundidade e com o merecido tratamento estético. Portanto, seu caminho o conduz a um Teatro Musical.

Não no mesmo sentido da Gesamtkunstwerk ${ }^{143}$ realizadas por Richard Wagner e que tiveram uma influência essencial nos caminhos percorridos pelo teatro europeu, nem somente nos modelos orientais, que situam a orquestra no palco. Mesmo bebendo dessas fontes, o Teatro Musical de Meyerhold aprofunda certas questões, abrangendo sempre os papeis a serem desempenhados por todos os envolvidos na criação cênica e a função crítica da arte.

Então, qual a noção de Teatro Musical?

De forma ampla, essa expressão é utilizada para designar todo gênero artístico que mistura elementos teatrais e musicais, não importando a proporção de sua utilização. Desde que integradas música, texto e elementos visuais.

Em outra percepção, designa um teatro onde não é possível separar claramente as funções do ator das de um músico e das de um dançarino, pois o intérprete deve ser capaz de convergir essas artes em seu corpo. Esse é um teatro que utiliza a música para fins dramáticos, no qual os componentes musicais e teatrais se equivalem.

Há, ainda, comercialmente uma ideia de que o Teatro Musical é um gênero importado da Broadway, em forma de franquia, onde o foco é o entretenimento do público e nesse espetáculo se apresentam, num

\footnotetext{
${ }^{142}$ MEYERHOLD, V. E. O Professor Bubu e o problema do Espetáculo com Música, 1o de janeiro de 1925. Apud CHAVES, Yedda. 2001. Op. cit. p 91

143 "obra de arte comum" ou, "global", geralmente traduzidas por "obra de arte total"
} 
mesmo palco, atores, bailarinos e cantores, que por vezes revezam-se nesses papéis, sem no entanto precisarem passar por um processo de incorporação deles, mas mostrando seu virtuosismo em apenas uma dessas linguagens, ficando a "função" de ator subordinada às outras duas.

Nenhuma dessas definições, no entanto, "corresponde à noção de teatro musical que se depreende da prática de Meyerhold, na qual as relações entre teatro e música não são de equivalência, mas extremamente complexas e variáveis. Em sua obra, o "teatro musical" seria uma forma de teatro dialogado em que o papel da música, audível e inaudível, é o de valorizar o texto, estruturá-lo, aprofundar seu sentido, encená-lo afinal. Seria um teatro dramático, no qual a música tem um papel essencial na encenação de um texto."144

A música não ilustra ou reforça as ações, ele é a sua base, sua estrutura, uma vez que, com o corpo, o ator a realiza para executar as ações que lhe foram designadas. Tudo é musicalizado: o texto, o gesto, o olhar, a iluminação.

Num espetáculo meyerholdiano, a música se combina a partir de duas fontes principais: o diretor e o texto. Essa estrutura leva Meyerhold a elaborar, a partir de 1930, o princípio do Realismo Musical. Esse movimento em seu fazer teatral significa um amadurecimento pós reação ao naturalismo e a toda sua experimentação simbolista. No realismo musical todo o espetáculo é composto como música, audível ou não, desde a dramaturgia. Ele sabe utilizar bem a música tanto em sua força de estruturação e organização, quanto em seu impacto emocional, lírico ou crítico.

"Há uma evolução na história das relações entre teatro e música na cena meyerholdiana. Essas relações vão da fusão, no uníssono das séries musicais, visuais, faladas, gestuais, em um conjunto harmonioso que visa a provocar a hipnose no espectador - já em curso em 'Tristão e Isolda' (1909) e magnificamente realizada no 'Orfeu' de Gluck (1911) - até o desenvolvimento de uma estratégia de contraponto em que cada linha permanece autônoma, portadora de um

${ }^{144}$ PICON-VALLIN. 2008. op. cit. p. 20-21 
sentido diferente, num conjunto de tipo polifônico que suscita emoções ativas e não procura criar qualquer tipo de encantamento." ${ }^{145}$

Dispensa um tratamento cuidadoso ao texto e aos sons. A primeira lição do ator é ativar sua escuta. Meyerhold cuida de cada palavra e de cada frase, introduzindo expressões vulgares e sonoridades estranhas para promover o deslocamento de significação do texto, para sua sonorização. Busca as transições, tonalidades e fluxo sonoro no texto, mas principalmente, as zonas de ruptura, as modulações.

Outro trabalho importante para seus atores é o coletivo musical, encontrado na maior parte das vezes a partir do coro. As reações e sonoridades, quando couberem, acontecem coletivamente. Para isso, reparte vozes a fim de encontrar uma polifonia em que cada voz responde a exigências opostas: encontrar sua ancestralidade enquanto povo russo e responder a exigências musicais convencionadas.

Ao analisar o "Inspetor Geral", de Gogol, Meyerhold observa que este espetáculo "é uma espécie de jazz-band secreto em que o som sai não se sabe de onde, como o ronco de uma barriga. Existe um milhão de sons no espetáculo, orquestra humana de percussões: batidas sobre a mesa, sapateado, peões que se misturam sobre o tabuleiro"146 entre outros.

Todo esse trabalho com o som passa por um caminho de incorporação para o ator, que escolhe executá-lo desta ou daquela maneira, conforme as instigações que receba do encenador.

A música audível funciona em níveis múltiplos e simultâneos: avisar, convocar, atrair, hipnotizar aumentar ou reduzir a voltagem emocional, aprofundar a atmosfera e a ação, transformar o cômico em horrivelmente estranho, colorir qualquer anedota do cotidiano, transformando-a em fato psicológico importante. ${ }^{147}$ Buscava exprimir o essencial, aquilo que o discurso não daria conta sozinho.

Em relação à música inaudível, é essencial, pois compreende que ninguém além do ator é capaz de garantir a fluidez da cena e

\footnotetext{
${ }^{145}$ Idem ibidem. p. 23

${ }^{146}$ MEYERHOLD. Apud PICON-VALLIN. 2008. op. cit. p. 29

${ }^{147}$ ASAFIEV, Boris. A Música no Drama. Apud PICON-VALLIN. 2008. op. cit. p. 30
} 
do espetáculo. Assim, deve ouvir muitas vezes a peça e estar presente o tempo todo, mesmo quando esteja fora de cena. Isso fez com que pensasse em camarins que dessem diretamente no palco.

É a partir da música inaudível que se estabelecem os rastros. Se o espetáculo é contínuo, deve assim fluir, por esse motivo é necessário aprender a trabalhar com as modulações, que serão responsáveis pela passagem de uma parte a outra das cenas e do próprio espetáculo. "Representar as modulações, diz Meyerhold, é concentrar a atenção no passado, sobre o que acaba de ser levado à cena, e sobre o futuro, sobre o que vai ser representado." ${ }^{148}$

$\mathrm{Na}$ prática do Teatro Musical, Meyerhold encontra na música o elo capaz de friccionar de forma polifônica todas as linguagens em relação ao público. Essa música inaudível garante a conversa entre dramaturgia, encenação, atuação, sonoplastia e iluminação, pelo menos. E assegura que todos estarão criando tensões em relação à plateia. Tudo isso enfrentando uma questão musical fundamental, o tempo.

"Meyerhold substitui o trabalho introspectivo, o jogo psicológico, pelo trabalho musical do ator. A questão: ‘Que tempo para a peça?' induz à questão do tempo nos diferentes episódios, de suas sequências e de cada um de seus papéis.

Enfim, o ator transforma sua palavra em canto, de todo modo situa seu discurso na fronteira entre o falado e o cantado. Quando o 'Inspetor Geral' é apresentado em Paris, em 1930, (...) Robert Kemp escreve: 'Talvez tenham torturado o texto, mas ele não foi de maneira nenhuma menosprezado; ele é tudo, ele é exaltado. Seu ritmo é acentuado e cada frase é uma melodia.'

Produzida durante o espetáculo no palco (ou off) por um piano ou uma orquestra, invisível durante a maior parte do tempo, a música é, portanto, também produzida pela encenação, pelos atores, cujo sentido musical é convocado para um atuação coletiva, audaciosa, engajada fisicamente e vocalmente. Força emocional dessa 'orquestra' de atores: sua atuação, assimilada a uma interpretação musical, provoca a

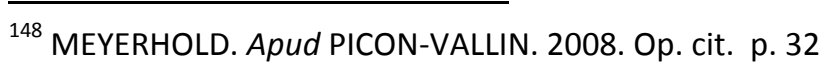


adesão dos espectadores, sem, contudo, apagar os ganhos da distância em relação às personagens. ${ }^{149}$

Essa qualidade de produzir um ator capaz e competente física, mental e emocionalmente de criar personagens profundos e estabelecer partituras corpóreas e vocais não naturalistas, sempre pautando seu trabalho na música, é que possibilitou o aprofundamento do realismo musical. Este, por sua vez, assegura o desenvolvimento do Teatro Musical.

Este teatro, fundado em relações musicais entre as pessoas e as linguagens que o compõem e em princípios musicais enquanto norteadores da formação desses profissionais, é um catalisador de conexões emocionais com o público, que só podem ser conseguidas a partir do estado de música e em sobreposição ao estado de prosa.

Portanto, no Teatro Musical a partir dos fundamentos meyerholdianos, temos alguns elementos a serem considerados, que dividiremos aqui em fundamentais e pessoais.

Os fundamentais são os elementos essenciais à existência de um Teatro Musical, enquanto estrutura complexa e variável das fricções musicais entre as linguagens que o compõe. Podemos elencar os seguintes:

a) Música audível

b) Música inaudível

c) Polifonia

d) Fricção entre teatro, dança, música, artes plásticas e dramaturgia

Os pessoais, dizem respeito ao material humano envolvido na realização desse Teatro Musical, essencial às composições que se darão em relação a todas as pessoas e materiais envolvidos no espetáculo. Enumeramos os seguintes:

${ }^{149}$ PICON-VALLIN, Béatrice. 2008. Op. cit. p. 34 
a) Um ator musical

b) Encenador musical, capaz de provocar os elos musicais das outras linguagens envolvidas no espetáculo

c) Dramaturgia musical

d) Formação a partir da musicalidade para os profissionais do teatro

e) Ressonâncias na plateia

A proposta de um teatro fundado na música, que seja pensado, estudado e realizado a partir dela, organiza, sem deixar de lado sua multiplicidade inerente, as relações complexas e variáveis que o constituem. A música passa a ser o elo e não apenas a linguagem, pois até enquanto linguagem deve responder musicalmente ao elo.

"Ausente, ela contamina a esfera sonora de um espetáculo pela musicalização do texto e do gestual. Ela organiza o espetáculo, pois apenas ela pode fazer com que sejam ouvidos, ao mesmo tempo, o conjunto, obra do diretor, e cada uma das vozes que dele fazem parte. Ela substitui os elos lógicos da continuidade da intriga pelos elos associativos, encobre os choques inerentes à técnica da montagem, mas sem apagá-los, cria outros, insere ênfase. Ela sustenta o trabalho do ator." 150

${ }^{150}$ Idem ibidem. p. 22 
CONSIDERAÇÕES FINAIS:

\section{A musicalidade na composição cênica do ator}

Não estacione, não se repita, busque o novo.

Yedda C. Chaves ${ }^{151}$

Nesta parte do trabalho, procuramos dividir com o leitor as experiências vividas e o caminho percorrido na busca de conexões que tornassem possíveis ao ator o trabalho a partir da musicalidade.

Por esse motivo, dividimos em 3 movimentos que se sucedem não apenas cronologicamente, mas enquanto possibilidades de práticas e de composição de saberes racionais e afetivos.

A leitura dos movimentos expressa o que pudemos agregar do material colhido e aqui compartilhado, mesmo que por vezes denotem um "retrocesso" no modo de pensar o trabalho do ator, porquanto quisemos manter as ideias essenciais de cada período dessa pesquisa, afim de que o leitor pudesse compreender o percurso também a partir dos rastros.

- 1 - movimento: Uma experiência na instrumentalização do ator para um teatro musical

A busca por um trabalho de ator a partir da musicalidade nem sempre esteve evidente como tal durante esta pesquisa, mas duas coisas, em geral, sempre causaram muito incômodo nos trabalhos que realizei, participei ou simplesmente assisti: o ator não estar pleno em cena e a separação marcada entre as linguagens artísticas. Obviamente há exceções, atores integralmente no aqui e agora de sua atuação e em plena conexão com o público, assim como espetáculos que ultrapassam as barreiras da

${ }^{151}$ (informação verbal) 
autoafirmação da linguagem e se completam enquanto arte. Mas justamente porque o que poderia ser regra, pareciam braços desviados do rio, com a atenção voltada a esses dois pontos, passamos a buscar questões que pudessem dar pistas de caminhos a seguir.

Acreditando que a presença do ator em cena é o que torna crível sua arte e que esta se dá a partir de uma experiência múltipla de linguagens conectadas. Encontrei guarida, por 2 anos, no CEPECA (Centro de Pesquisa e Experimentação Cênica do Ator) do CAC/ECA, coordenado pelo Professor Dr. Armando Sergio da Silva. A pesquisa realizada ali foi o berço deste trabalho e me colocou em contato com algumas das fontes teóricas iniciais.

A proposta de pesquisa, naquele momento, objetivava a criação de um trabalho completo do ator no sentido da utilização de todos os recursos físicos e emocionais ao mesmo tempo, partindo da experiência que vivera até aquele momento participando de espetáculos musicais ${ }^{152}$ e enquanto formador de atores. Nessa vivência, pude sentir o quanto o trabalho de um ator pode ser complexo, na medida em que alia dança, canto e interpretação na mesma ação cênica, concomitantes, inseparáveis, precisamente colocados e preenchidos de sensações.

A teatralidade era um foco importante, enquanto catalisadora de ações artísticas e fomentadora de um pensamento mais crítico em relação ao papel do ator e do encenador. Não interessava mais a cópia da vida como "demonstração" do cotidiano, mas seu aprofundamento enquanto ato de escancarar as máscaras e mecanismos sociais, o que parecia somente poder ser feito a partir de corpos e vozes que ressonassem um mundo múltiplo e dissonante. Neste momento a música parece ser um dos elos possíveis a dar conta de tamanho desafio.

Nesse sentido afirma Cintra, "a encenação no século XX passa a ser tratada, a partir de Appia, Stanislavski e Meyerhold, como um

\footnotetext{
${ }^{152}$ Revivendo Brodway, direção de Ronaldo Gutierrez, SP, 2005/06; It's show time, folkes!, direção de Ronaldo Gutierrez, SP, 2007/08; Brotos Legais, direção de Jamil Dias, SP, 2009; entre outros.
} 
discurso que guarda similaridades com o discurso musical, principalmente no que diz respeito à questão do tempo e, como decorrência, do ritmo. $O$ resgate da teatralidade trouxe para o primeiro plano, desde o início do século, a problematização dos aspectos temporais da cena, como parte da reflexão sobre as novas formas de construção de sentido na narrativa teatral. Aos poucos, a temporalidade passa a ser elemento central na construção de poéticas distintas, sejam poéticas do real ou do irreal. O tempo cênico passa a ser usado como ferramenta para a construção de tempos ficcionais" ${ }^{153}$.

Mesmo um século depois, compreender o trabalho do ator e do encenador enquanto ato musical é dialogar com a cena contemporânea, uma vez que estrutura e organiza esses ofícios em fenômenos sonoros e temporais e não essencialmente no espaço. Começamos a imaginar o trabalho do ator enquanto composição, possuindo como eixo central a musicalidade.

Constituímos, então, um grupo de atores que estavam dispostos a investigar um trabalho que partisse da musicalidade e que utilizando fontes oriundas da música e de outras linguagens, se costurasse musicalmente, respeitando um tempo e um ritmo que somente poderia ser alcançado naquela própria costura. ${ }^{154}$

A utilização da música não é novidade. As técnicas de desenvolvimento vocal, desde a Grécia Antiga, vinham, ainda que em parte, do canto. Odete Aslan retrata essa utilização também na Commedie Francaise, onde várias teorias se defrontam levantando o questionamento de se "deveriam usar o canto para colocar a voz de um comediante, ou de exercícios de voz falada? (...) Jean Galland, por exemplo, adaptava para a voz falada alguns exercícios cantados. Os amaciamentos tendiam a aumentar a tessitura do registro falado para que este cobrasse três oitavas." 155

\footnotetext{
${ }^{153}$ CINTRA. 2006. op. cit. p. 92

${ }^{154}$ As infromações sobre o grupo e uma lista com alguns exercícios aplicados constam no anexo B

${ }^{155}$ ASLAN. 2008. p. 13
} 
Possuindo uma existência tão ligada à origem da arte, e do próprio teatro, a música não deveria ter sido dele dissociada, uma vez que inerente ao fazer artístico humano as noções de tempo, ritmo, consonância e dissonância.

O desafio do grupo seria experimentar um amadurecimento das formas e ferramentas utilizadas para a musicalidade no trabalho do ator e na cena, com o desenvolvimento conjunto e já direcionado de todos os seus elementos. Utilizar corpo, voz, interpretação concomitantes, desde a criação do ator e da cena, a partir de uma musicalidade própria desse ator e também sugerida, por mim, a ele.

Mas essa conversa entre música e teatro, que nos parece tão óbvia hoje, não se apresentava como algo tão natural ou fluente. Essa dificuldade, nascida na formação disjuntiva que recebemos, que segrega também as artes e suas práticas, nos obrigou a debruçar a pesquisa sobre as possibilidades de friç̧ão entre a música e a cena no corpo do ator. Buscamos uma consciência cênica que parte dos estudos teóricos, mas somente se completa e realiza após a experimentação prática.

Para isso, utilizamos como bases teóricas musicais três autores que, por sua visão emancipada da música, nos parecem mais adequados a um trabalho que busca atores que se posicionem ética e artisticamente de forma crítica, em um teatro que não segue diretrizes do naturalismo, ainda que possa caminhar com o realismo, buscando a provocação da plateia. Murray Shafer, John Cage e Dalcroze têm em comum a ruptura com uma visão tradicionalista da música, o que significa que conservam as tradições, mas, apropriando-se delas, superam rigores que não permitiriam ao estudioso deixar a partitura e ouvir outras sonoridades.

A música vista como uma experiência estética não excludente, da qual as sonoridades do mundo poderiam fazer parte e compreendida a partir do movimento e da rítmica, é algo que dialoga diretamente com o fazer teatral.

A partir daí, passamos a compreender como alguns conceitos musicais poderiam ser experimentados no corpo e levados à cena. Tais conceitos estão desenvolvidos no capítulo 2 . 


\section{Ephtah! Abre-te ouvido!}

Nossa experiência na instrumentalização do ator para a composição cênica a partir da musicalidade, tem início com práticas que buscam despertar e aguçar a escuta desse ator. Cremos que somente será possível responder à musicalidade se estivermos munidos de uma escuta ampla. $O$ ato de escutar deve dar conta de receber os sons, identificá-los, realizar escolhas sobre eles para finalmente abstrair e comparar informações diversas a fim de incluir apreciações sobre elas.

Essa prática sobre o ouvir deve ser intensa, para, então, ser ampliada às ações do próprio indivíduo. Veja que falamos aqui do homem, pois é importante levar esse exercício ao ser humano que atua, dando-Ihe oportunidade de incorporar em sua vida a ação de escutar, para que ele possa trazê-las para o trabalho de ator. Assim, desde a identificação até as apreciações, o ator, em sua vida, deve repetir esse roteiro básico de escuta, com seu corpo, com suas emoções, com seu raciocínio e com sua intuição. Isto é parte da sua formação e, em que pese possa torná-lo uma pessoa mais preparada à convivência e aos jogos que a vida oferece, ele só estará exercitando sua escuta enquanto ator, quando puder realizá-la enquanto ser.

Não é possível dissociar o humano do ator, nem devemos pretender fazê-lo, se quisermos compreender a ambos em suas formas múltiplas. A esse respeito, mas falando do Teatro Oriental, Bonfitto escreveu:

"E aqui nos deparamos com uma outra questão, que é uma divisão temporal entre formação e exercício da profissão. A linguagem é estruturada através de personagens que encontram uma correspondência com os diferentes níveis de conhecimento do ator em relação à própria arte. E tal percurso está previsto para durar a vida inteira do ator. Ou seja, a necessidade de dedicação integral não é somente a expressão de uma atitude de fundo religioso, mas ainda uma necessidade objetiva para que possa dar vida a uma linguagem extremamente complexa e detalhada..."156

${ }^{156}$ BONFITTO. 2002. op. cit. p. 15 
Parte do trabalho de exercitar a escuta é conhecer alguns conceitos para identificá-los, dentro e fora de cena. Na vida eles possuem as definições que alcançarem ao longo do tempo e naquele espaço territorial específico. Em cena, devem ser acordados entre todos os artistas envolvidos no processo criativo.

Partimos de conceitos dados pelas nossas fontes teóricas, para num segundo momento podermos entender quais seriam os conceitos mais importantes ao nosso trabalho e, ainda, quais os conceitos que precisaríamos talhar. São exemplos dos conceitos musicais trabalhados para a composição de um repertório comum entre os atores: poluição sonora, escuta acusmática, silêncio, som, ruído, timbre, amplitude, melodia, textura, ritmo e paisagem sonora.

Apenas para reconhecimento, propomos alguns resumos dos conceitos enumerados, conforme composição encontrada pelo núcleo onde as pesquisamos:

a) Poluição sonora: conjunto de sons emitidos a todo instante por um fragmento de uma cidade ou local. Existe porque as pessoas não são atentas ao que ouvem, então acabam ouvindo tudo junto, misturado, sem se preocupar em identificar cada som ouvido;

b) Escuta acusmática: desenvolvida por Aristóteles que andava enquanto falava a seus discípulos, por vezes escondendo-se entre cortinas, com o intuito de ativar o cérebro na busca de identificar de onde vem o som, mantendo a conexão com os ouvintes;

c) Silêncio: é a ausência de som. (já explicado no capítulo 2). É a característica mais cheia de possibilidades da sonoridade, pois tudo pode quebrá-lo. (para John Cage, silêncio hoje é ruído)

d) Som: é aquilo que corta o silêncio. São todas as possibilidades de combinações de vibrações de ar.

e) Ruído: é qualquer som que interfere em algo que escolhemos ouvir, dificultando ou impedindo a experiência da escuta selecionada. "O que para uma pessoa é música pode ser ruído pra outra. Mas mantém aberta a possibilidade de haver, em 
determinada sociedade, mais concordâncias que discordâncias de que sons consistem em interrupções não desejadas" ${ }^{\prime 157}$

f) Timbre: é a superestrutura característica de um som que distingue um instrumento ou uma voz de outra, na mesma frequência e amplitude. É a cor do som, podendo mudar o resultado sonoro da mesma palavra ou evento sônico.

g) Amplitude: é a dinâmica do som (forte e fraco). Acrescenta uma terceira dimensão ao som pela ilusão da perspectiva, fazendo o som se movimentar conforme a vontade de seu emissor entre 0 horizonte acústico e os tímpanos do ouvinte.

h) Melodia: é o passeio do som. Movimenta o som em diferentes frequências. Na fala causa as inflexões.

i) Textura: É o entrelaçamento dos sons produzidos, como a trama formada pelos fios de um tecido. Quando há tensões entre os "fios" realizamos o contraponto.

j) Ritmo: é a direção para onde é moldado o som, cria um percurso para ele.

k) Paisagem sonora: é o ambiente acústico do mundo que habitamos. Pode ser compreendida dentro de um reduzido espaço físico como uma sala de aula, um banheiro ou um saguão de hotel, ou, de forma macro, por um bairro ou uma cidade.

De todos os conceitos, o primeiro a ser trabalhado foi o de música: é movimento que se dá no espaço, durante algum tempo e que possui qualidades que alteram sua percepção (como ritmo, duração e altura). A partir desse princípio, o grupo de pesquisas passa a experimentar formas de ações físicas e vocais não realistas, mas que abordem exatamente fazeres cotidianos massificados pela nossa inércia em repeti-los. Tornar o movimento musical era nosso segundo desafio

${ }^{157}$ SCHAFER, Murray. A Afinação do Mundo; uma exploração pioneira pela história passada e pelo atual estado do mais negligenciado aspecto do nosso ambiente: a paisagem sonora. Trad. Marisa Fonterrada. São Paulo: Editora UNESP, 2001, p. 367 
A essa altura o leitor pode estar se perguntando, como utilizar música para exercitar novas possibilidades cênicas, não-realistas e ainda assim aprofundar no cotidiano(ver item 3.2.)? Propomos a você um exercício: Escolha uma música qualquer. Ouça-a atentamente. Perceba os diferentes sons que ela emana. Vozes, instrumentos, pulsos, contrapontos. Imagine que ações do cotidiano você poderia praticar a partir dela. E perceba quantas coisas diferentes você poderia fazer nessa musicalidade. E coo essa musicalidade pode mudar a sua ação. Viu? Utilizamos apenas você e uma música e quantas oscilações foram capazes de surgir? Imagine agora se passássemos a pensar numa música também para uma personagem que você irá interpretar? E como se daria a relação entre essas duas músicas? E as relações entre a música que você pensou e a pensada por outro?

Muitos exercícios foram realizados no sentido de descobrirmos os movimentos e sonoridades musicais de nosso corpo e, também, de como cada um daqueles conceitos musicais afetavam e habitavam nosso material inicial de trabalho. O importante é que tínhamos a consciência de que esses conceitos devem fazer sentido, também, fora destas páginas, na sala de estudos e na sala de ensaios, mas principalmente no corpo do ator.

Passamos então por um momento intenso de experimentação a partir de exercícios que buscavam colocar em jogo a música e a musicalidade, de forma muito livre, pois era a fase de recebimento e identificação desse trabalho. ${ }^{158}$

Esta etapa foi imprescindível para percebermos que o trabalho iniciado sobre si mesmo mostra-se muito eficiente, do ponto de vista de que enquanto permite ao ator encontrar musicalidades no seu corpo-menteemoção, as libera, revelando a si mesmo. Isto pois, a partir dos exercícios de criação de um repertório inicial (instrumentalização ao trabalho) o ator é lançado à uma prática bastante diferente, uma vez que busca conectar corpo,

${ }^{158}$ A maior parte desses exercícios estão descritos no Anexo D 
voz e interpretação à mente e à emoção, a partir das músicas propostas a eles e das propostas por eles.

Lançar-se ao novo, ao risco, é possibilitar a descoberta do ser que se lança, se ele for instigado a observar-se a partir de diferentes pontos de vista. O risco é capaz de provocar um deslocamento no ofício do ator, fazendo dialogarem as ações cênicas, ele próprio e o espectador. É nessa fresta que se abre entre a certeza das ações a serem realizadas e as dúvidas sobre o que desconhece, mas que precisa enfrentar, que reconhecemos, no ator, o homem.

Isso traz o público para a cena, pois reconhecemos o humano na arte. E mantém o diálogo com esse público, uma vez que não é ao humano que estamos saboreando, mas a atuação viva de alguém cujo trabalho é criar magia pela arte. No entanto, nas palavras de Ludwik Flaszen, essa magia só acontece quando o teatro consegue convencer o público, tanto no sentido de ser crível quanto no de provocar-lhe alteração de estado ou reflexão, neste caso "o teatro, por sua natureza, interpenetra-se na esfera, para nós civilizados vergonhosa, da magia. Ou não existe." 159

Nasce uma nova tarefa, não se deixar seduzir pelo "estado mágico" que a própria música instaura, como artifício para a realização do trabalho. Em outras palavras, a música tocada, cantada ou dançada já produz, por si, uma transformação no espetáculo e no estado de recepção daquele que dele participa como ator ou espectador. Para se manter no estado de risco, os atores precisam buscar em seu corpo-mente-emoção a realização da musicalidade. Entender como criar tais estados a partir desse material primário, ainda que em contato, direto e indireto, com a música.

Já que não possuíamos respostas, algumas questões pedagógicas passaram a nortear nosso trabalho: o que desafia 0 ator? Quando ele se coloca em risco? O mesmo exercício desafia todos os atores?

\footnotetext{
159 FLASZEN, Ludwik. O Teatro Condenado à Magia. In O Teatro Laboratório de Jerzy Grotowski 19591969 / textos e materiais de Jerzy Grotowski e Ludwik Laszen com um escrito de Eugênio Barba, curadoria de Ludwik Flaszen e Carla Pollastrellip com a colaboração de Renata Molinari, Tradução para o português de Berenice Raulino. São Paulo. Perspectiva: SESC, Pontedera, IT: Fondazione Pontedera Teatro, 2007, p. 84
} 
Em geral entendemos que se 0 ator passa pela vivência, isso já basta. Mas cremos ser necessário que conheça os fundamentos do que está fazendo. Desvendar as premissas da musicalidade em seu corpo parecia ser o desafio a ser lançado, sem a obrigatoriedade de dar respostas, como um fundamento da própria proposta pedagógica da pesquisa. Enfrentar e superar os limites para alcançar, por si, as respostas era um pressuposto.

A partir das investigações sobre a musicalidade, percebemos duas coisas importantes. Em primeiro lugar, houve uma aceleração na construção de um coletivo enquanto agente criador a partir da utilização da música, dentro das propostas que elaboramos. Ela potencializa as relações em diversos níveis, integra e fricciona as pessoas e as coloca em constante diálogo com o ambiente. Isso constrói um local comum de diálogo e de desenvolvimento do trabalho, não apenas pelo vocabulário musical inserido, mas, e principalmente, pela comunicação verbal e não verbal que nasce das conexões estabelecidas por esse coletivo, fazendo com que os atores compreendam melhor a si mesmos em relação às propostas, aos outros e ao espaço, já que há uma organização musical não racional que se estabelece.

A segunda coisa, é que cada ator compõe um repertório de trabalho cênico diferente. A observação dessa construção nos leva a crer que isso se dá, essencialmente, pelo fato de partirem de repertórios anteriores. Obviamente, o trabalho não despreza os rastros de cada ator, seu percurso anterior. E, como era esperado, cada um inicia o trabalho sobre os conceitos musicais a partir de um lugar que já fora anteriormente construído. Isso faz com que toda a composição que segue caminhe a partir dali.

Isso se torna mais interessante quando observado em diálogo com o lugar coletivo construído. Se há duas composições nesse grupo, uma coletiva que é compreendida e acessada por todos, ainda que cada um a seu modo, e uma individual, que integra o conjunto de investigações de cada um e não encontra identificação direta na investigação dos demais, embora nelas ressoe, temos dois traços de cada um dos atores envolvidos. Esse são 
elementos essenciais para revelar o ator. Tanto o que ele compõe de plural, quanto de singular. Há uma autonomia alcançada por ele quando reconhece tais elementos, que reflete na continuidade do trabalho, potencializando-o à novas descobertas. O que ele já possui enquanto repertório, após identificado pelo corpo-mente-emoção, permite que ele se lance ao novo. E é nesse lugar que posicionamos nossas propostas, a fim de permitir a incorporação de alguns modelos musicais de responder à cena.

É chegado o momento de fazermos as escolhas sobre o material levantado e, finalmente, abstrair e comparar informações diversas para, num terceiro momento, incluir apreciações sobre elas. Continuávamos exercitando nossas escutas.

Elegemos um texto inicial, "Caos" de Millor Fernandes, como material dramatúrgico para as experimentações cênicas, por entender que sua composição em lidar com o cotidiano de forma a extrapolar suas fronteiras, poderiam nos conceder elementos importantes para fazer o mesmo trabalho no corpo do ator. A partir do desenvolvimento dessa experimentação, compreendemos que uma coisa não está, necessariamente, ligada a outra. O corpo do ator emancipado é capaz de criar por si essa ponte. Mas, essa descoberta veio com o amadurecimento da pesquisa, quando, mais tarde, abandonamos o texto citado e passamos a praticar com outros.

Foi nesse momento que tivemos acesso a algum material de Meyerhold e, aliando aos estudos que fazíamos a partir de Schafer, passamos a elaboração de alguns jogos teatrais-musicais. Não nos referimos a jogos teatrais que utilizem música, mas a propostas que coloquem os atores no jogo cênico a partir da musicalidade.

A partir desses jogos trabalhamos as propriedades do som e alguns conceitos musicais no corpo-mente-emoção do ator. Grave, agudo, forte, fraco, longo, curto, dissonante, consonante, polifônico e uníssono passaram a fazer parte do treino diário em busca que apropriarmo-nos dos elementos musicais, mas agora a serviço de uma, ou de algumas, dramaturgias. 
Com a inserção de um texto, fomos instigados a trabalhar com propostas de outras dramaturgias, procurando os pontos de contato entre elas e o trabalho do ator, para afiná-las. Buscamos um diálogo das dramaturgias. Dramaturgia da luz, do som, do cenário, do ator, do encenador, do design de aparência e do texto. Tudo em constante fricção.

Toda essa prática nos obrigou a compor um material comum. Nesta etapa as diferenças nas formas como cada ator participante da pesquisa a incorporava não parecia ser relevante, pois havia um outro objetivo comum a todos os envolvidos, a composição cênica, e para lá eram direcionados os esforços.

O que ficava mais nítido agora, era o fato de que, partindo sempre da música, não havia qualquer separação entre canto, fala, dança, gesto, interpretação e performance. Estava tudo ali, sem separações, de forma múltipla naquele contexto, porque haviam sido tecidos juntos. Os atores não precisavam ser lembrados ou provocados a todo instante a modularem seus corpos e vozes, o faziam naturalmente, como parte da cena, passeando entre cantos e falas, entre ações cotidianas e extracotidianas e entre gestos e danças. Havíamos composto uma potente pedagogia nesse sentido.

É exatamente aqui que encontramos em Meyerhold todo aprofundamento que precisávamos para a pesquisa no sentido do trabalho do ator. Havia iniciado, sob orientação e condução da professora Yedda, estudos e treinamentos a fim de preparar meu corpo-mente-emoção a partir das vivências e estudos que ela havia realizado a respeito de Meyerhold, neurociências e outras fontes correlatas. Além disso, tive a oportunidade de acompanhá-la, como assistente, em suas aulas na graduação do CAC/ECA/USP.

Amparados, ainda, pela disciplina oferecida pela professora, "V. Meyerhold e o Ator do Futuro: Processos de Incorporação Vistos pelas Neurociências", passamos a preencher nosso trabalho com os fundamentos da musicalidade meyerholdiana. Todo esse aporte, recebido pela 
oralidade e pela prática por mais de dois anos, foi fundamental para a construção dos próximos movimentos.

Continuamos elaborando os exercícios a partir dos conceitos de Schafer, que permitem maior amplitude na experimentação musical, aliando-os a alguns princípios da Biomecânica e das lições deixas por Meyerhold em seus estudos e encenações, passamos a compor cenas que contivessem, por exemplo, paisagens sonoras, rastros, acentos e pausas, suspensões, reserva, otkaz, possil e totchka entre outros fundamentos de trabalho, ou seja, pautadas em musicalidade.

As experimentações eram riquíssimas e contribuíam para agregar a cada ator, segundo relato deles, mesmo em trabalhos realizados em outros contextos e com outras pessoas, para uma presença global mais expandida e para conexões mais profundas em diversos níveis da criação, tanto nos ensaios quanto nas apresentações.

Como era desejo desse coletivo, compusemos uma dramaturgia base, a partir de duas músicas ${ }^{160}$ da Banda "Os Mutantes", e do texto do Millor Fernandes, que já havíamos estudado. A existência de uma encenação possibilitou que começássemos a refletir sobre a musicalidade da cena e em como ela é alterada pelas demais musicalidades, do ator e dos outros artistas envolvidos.

Realizamos algumas mostras desse processo, inclusive no TUSP ${ }^{161}$, e estávamos instigados com os lugares alcançados. Era visível em cada um e em todos, enquanto conjunto, o processo de encarnação da musicalidade enquanto princípio disparador do processo criativo no corpo e na mente, capacitando a conexão de emoções e principalmente atravessando a quarta parede e produzindo musicalidades reativas no público.

Obviamente são muitas coisas a serem observadas e acontecendo todas ao mesmo tempo, numa multiplicidade semelhante à humana e que nem sempre somos capazes de documentar com a inteligência

\footnotetext{
${ }^{160}$ Os detalhes desse estudo com os 5 atores e o CEPECA, constam no anexo B

${ }^{161}$ Anexo C
} 
racional, mas que certamente captamos com a inteligência afetiva e com a pulsão.

Alcançava um lugar muito interessante na pesquisa. Não tão "acadêmico", num sentido de documentável e racional, mas por outro lado, altamente científico e perceptível se levado em conta o repertório inicial e o atual de cada ator e do grupo. O trabalho de pesquisa com o grupo de atores havia alcançado lugares interessantíssimos.

Mas era necessário mais. Era preciso um mergulho mais profundo, com recorte mais precisos e para destinos ainda mais desconhecidos. Precisávamos de um outro movimento.

\section{- 20 movimento: fomentar a formação musical}

Nossa pesquisa possui como objeto principal o Ator Musical. Este termo vem em consonância com a ideia de Teatro Musical de Meyerhold (Item 3.5.3.). Um teatro dramático no qual a música tem um papel essencial para encenar um texto. A música não ilustra ou reforça as ações, ela é a sua base, sua estrutura, uma vez que, com o corpo, o ator a realiza para executar as ações que lhe foram designadas.

O ator musical, portanto, estará presente sempre que, desde o processo criativo e até as apresentações para o público, o ator possa escolher a variação de tempo-ritmo, durações e alturas, propondo e executando uma musicalidade, quer para a peça, quer para determinadas cenas, ou até para cada conjunto de falas, deixando o lugar comum e passando a reger sua produção cênica de forma emancipada, conectando-se à plateia e permitindo-lhe diálogos.

A questão era: como se daria o desenvolvimento da continuidade das pesquisas? Pensamos então numa instrumentalização, 
compreendida como a ampliação (ou a criação em alguns casos), de um repertório com vistas a permitir ao ator sua autonomia artística, o que por si já traria resultados incorporados.

As propostas, que claramente objetivam a instrumentalização para um Teatro Musical, partiam de concepções do humano embasadas em Morin (expostas no Capítulo 1) e buscava dar conta, a todo instante, de quatro elementos que consideramos fundamentais a partir da ideia de "Unitas multiplex": o global, o contexto, o multidimensional e o complexo.

O encontro com as neurociências, a partir da professora Yedda, nos incentivou a compreender esses elementos, também, por essa via.

Nesse percurso, pensando na formação do ator, buscamos saber como funciona o cérebro humano quanto às formas com as quais constitui o mundo e a partir das quais se relaciona com ele. Entendendo isso, podemos lançar um olhar sobre o trabalho de atuação (e também sobre o de encenação) que emane provocações ao público de forma mais completa.

Assim, conhecemos o que é chamado pela ciência de "estado central", que funde três dimensões de percepções para formar nossas representações sobre o mundo:

a) corporal: compreende o corpo, músculos, tecidos, órgãos, tudo que constitui o organismo;

b) extracorporal: representação do mundo; tanto do espaço sensorial, como do espaço do movimento percebido pelo corpo; estado de tensão dos músculos, ângulo das articulações etc.;

c) temporal: ocupada pelos vestígios acumulados durante 0 desenvolvimento do indivíduo, desde o nascimento até a morte. Provém do determinismo genético e da contingência histórica que integra os acontecimentos da existência.

A esse respeito, Adalberto Tripicchio, escreveu: "Para materializar esse estado central, temos de conceber um cérebro flou - 
somatório dos humores, hormônios e mediadores em ação no sistema nervoso. "O estado central é, ao mesmo tempo, a árvore e a floresta"162 $(\ldots)$

É, ainda, importante assinalar a correspondência da noção de cérebro flou com a ideia do chi da medicina oriental. Segundo Capra, esse conceito descreve padrões de fluxo e flutuação do organismo e suas interações com o meio. Implica numa descrição qualitativa de um padrão dinâmico resultante de processos e interações". ${ }^{163}$

Duas inspirações importantes podem ser extraídas do texto citado. A primeira, uma imagem, referente ao fato da multiexistência unitária, isto é, de sermos mais de uma coisa num só tempo. Somos a árvore e a floresta. A outra, uma instigação, a ideia de qualidade num padrão dinâmico resultante de processos e interações. Ambas nos devolvem aos quatro elementos, extraídos de Morin e enumerado acima, que devem ser considerados para a composição de um saber pertinente.

O ator é ao mesmo tempo parte e todo, assim como o homem, que muitas formações tentam esconder atrás desse ator. É árvore enquanto elemento constitutivo da arte teatral, do espetáculo, da célula criativa e fomentadora de criação, da unidade sobre a qual se concentra a semente da pesquisa e conexão com o mundo potencial. Finca suas raízes em solo teatral, mas expande seus galhos aos céus do mundo, deixando para o tronco a unidade que sustenta essa ligação.

É floresta enquanto elemento concretizador da arte em seu todo, da encenação em si, e das ressonâncias das dramaturgias em fricção. Constitui um elo entre todas as árvores e só existe a partir desse elo. $A$ partir dele, enquanto floresta, se estabelece a personificação de um evento teatral capaz de conceber e conceder frutos, sombra, mistério e perigos a todos que, provocados, atravessarem seu interior. É a existência a partir do

\footnotetext{
${ }^{162}$ Frase retirada da obra: VICENT, J-D. Biologia das Paixões. Lisboa: Europa-América, 1988.

${ }^{163}$ Informações disponíveis em julho de 2013 no site < http://www.redepsi.com.br/2007/07/10/oparadigma-da-complexidade-e-a-rela-o-c-rebro-mente/>
} 
coletivo. São vitais ao ser humano, pois capazes de oxigenar sua visão de mundo.

A outra questão que motiva a pesquisa é sobre a ideia de qualidade num padrão dinâmico resultante de processos e interações. As palavras em si já constituem uma provocação muito interessante. Buscar qualidade, num processo (portanto sem transformar em produto os lugares alcançados, mas assumindo a ideia de que pretendemos resultados) a partir de interações, ciente de que estamos lidando com algo vivo, mutável e mutante.

Havia, ainda, um terceiro motivador forte para as pesquisas realizadas nos encontros de formação dos atores, que vinham das instigações dos treinos e conversas com a professora Yedda. Essa transmissão oral e prática, tão cara ao fazer do ator, mas tão rara na academia, foi catalisadora de uma transformação nos modos de olhar e fazer teatro. Não era só de Meyerhold que me embebia naqueles encontros. Havia mais que um pensamento artístico-pedagógico sólido e uma prática impecável, digna de se ver repetida inúmeras vezes, pois por si só já era capaz de ensinar inúmeras coisas. Trata-se de um fazer que ultrapassa as barreiras da arte e satisfaz-se também na vida.

A questão do corpo-mente-emoção tratada neste trabalho é fundamental para a musicalização do fazer teatral. No entanto, quando vivida enquanto experiência, causa mais que ressonâncias, pois o processo de encarnação da compreensão do ser múltiplo e uno é algo que nos remete à nossa própria existência. Somos o unitas multiplex a todo instante, ocorre que não nos damos conta disso, nem somos lembrados disso o tempo todo.

Para a professora Yedda, do ponto de vista dos fundamentos, não havia distinção entre formação, estudos, práticas cênicas e vida. Tudo é vida. Somente isso pode garantir a integração entre mente e cérebro. Certa feita, indagada por mim sobre a postura corporal que conseguia manter sempre "empurrando o chão"164, inclusive pra beber água, sentada na

\footnotetext{
${ }^{164}$ Uma das bases do trabalho com a professora Yedda era o chão. Iniciávamos sempre colocando todo o corpo em contato com essa base, dialogando com ela e compreendendo como nosso corpo responde em relação a ela. Isso dá tonos ao ator, sem oferecer-lhe tensões.
} 
cantina, ela respondeu-me: "Não adianta trabalhar tanto na sala de estudos e ignorar o trabalho assim que eu cruzar a porta, não é?".

Compreender o trabalho do ator como eterno é a essência para qualquer formação. Em musicalidade isso permite, inclusive, que este ator possa fazer conexões musicais com o mundo e passe a compreender as músicas que nos cercam, as sonoridades que nos alimentam, direta ou indiretamente.

Tudo é estímulo para o trabalho do ator. E podemos possibilitar melhores respostas a esse estímulo. Somos formados a partir das coisas que vivemos e presenciamos. As relações cerebrais que produzem emoções são concretas e vêm do trabalho em conjunto entre o centro e o córtex. A partir daí surgem as respostas do corpo e as emotivas. Mas tudo acontece a partir do mesmo estímulo. Cérebro, corpo e emoção respondem concretamente a cada estímulo e agem concomitantemente, para criar respostas.

“A dicotomia 'menteXcorpo' não existe. A cognição deve ser incorporada, a mente corporada, a fim de se desenvolver um consciência pela ação física." ${ }^{165}$ A professora Yedda dizia que na arte não há ambiguidade, trabalhamos com isso, pois isso é trabalhar consigo mesmo. Assim, nos estudos, não se trata de "quero isso!", mas de compreender que a partir das experimentações, $80 \%$ será descartado, selecionando-se o que é melhor pra ficar.

É essencial ao ator compreender que seu trabalho não é realizar suas vontades. Que as propostas devem ser encaradas como material de trabalho, algo a ser desvendado, dissecado, devorado, enfim colocado em fricção com a pesquisa a ser feita. E que não deve manipular, conforme suas vontades, egóicas ou não, os resultados.

Cada dia é um dia de trabalho e o ator não é o mesmo todos os dias, dizia a professora Yedda, cada vez que prossegue numa

\footnotetext{
${ }^{165}$ CHAVES. 2010 (informações verbais)
} 
pesquisa ou processo, agrega coisas novas, por isso não deve sedimentar prematuramente seus experimentos. ${ }^{166}$

Aliada a tudo isso, há um material de Meyerhold, que conheci a partir da professora, que elenca 4 dotes essenciais ao ator:

1ㅇ) alma

$\left.2^{\circ}\right)$ intelecto

$3^{\circ}$ ) sinceridade + calor da interpretação

$\left.4^{\circ}\right)$ desenho refinado dos movimentos

O sentido de toda música no trabalho do ator, torna-se, então, claro quando a alma do ouvinte se funde à alma do compositor. Assim a palavra poderá se fazer carne, como ensinava o mestre russo.

Munido de tais questões, passamos a outro movimento, o do pedagogo-aprendiz. Se por um lado mergulhava no maravilhoso universo composto por Meyerhold, Schafer e vivências com a professora Yedda, por outro passava a colocar em prática as instigações nas turmas em que fui professor convidado no CAC (2010 a 2012) e na SP Escola de Teatro (a partir de 2011). ${ }^{167}$

Esta situação deu à pesquisa um outro olhar, o da formação do ator dentro de estruturas formadoras. Ainda que sejam ambientes que reconhecem que a formação se dá durante toda a vida, e que é impossível concluí-la no período em que frequentam suas instalações, há uma missão a ser cumprida, a partir de propostas delineados junto aos artistas-alunos, que pretendem carreiras como ator, encenador, dramaturgo, iluminador, sonoplasta, figurinista ou designer de aparência, cenógrafo e professor de teatro.

Nesta etapa da pesquisa pudemos experimentar um caminho diferente. Munido de algumas experiências vividas e experimentações

\footnotetext{
166 Idem Ibidem

${ }^{167}$ No Departamento de Artes Cênicas da USP ministrei aulas de Poéticas da Voz e do Corpo II, III e V e de Música II. Na SP Escola de Teatro, aulas no curso de atuação e atuei como encenador pedagogo, orientando experimentos cênicos.
} 
realizadas, vinha a seguinte questão: como utilizar o repertório que conquistamos, para instrumentalizar esse artista em formação, enquanto treino, e não provocando um adestramento?

Não haviam respostas. Pensando em acessar o ator a partir de outras vias, decidimos investir em dois caminhos: a pulsão e a inteligência afetiva. Assim, o corpo é quem pensa e trabalha. A racionalidade vem depois, como forma de observar a que organização o trabalho tinha sido levado a partir dos caminhos propostos. Propusemos um trabalho a partir da plasticidade dos movimentos e das sonoridades e do ritmo no espaço.

Buscando outras aplicações de Meyerhold, passamos a trabalhar com o ator fomentando sua composição, criando o espaço do jogo para ele. O ator não está livre para criar o que quer, mas está livre para criar a partir de uma estrutura proposta a ele e com a qual ele tem que se relacionar. As relações passam a ser o foco, sejam com as propostas, com o espaço, com o outro ator, pois o teatro nasce na presença em fricção com o outro. É uma camada para fora de si que deve ser revelada ou escondida, mas movimentada.

Nesse trabalho musical os encontros são a partitura onde os atores devem inserir suas "escrituras" com o corpo-mente-emoção. Não há espaço para grandes elucubrações, o jogo é instaurado pela musicalidade a partir da qual se clama a dança, o canto, a fala deslocada da significação cognitiva, o movimento plástico, ou seja, as fricções entre tempo e espaço a partir do teatro, da dança e da música. Por ser uma prática criativa, há espaço para tudo o que surgir, as únicas coisas evitadas são aquelas que representem o lugar comum de cada ator e de cada grupo de atores, bem como seus repertórios de segurança, aqueles costumeiramente acionados por eles quando solicitados. Uma das proposições mais repetidas é: "você já experimentou isso, agora faça diferente!".

Desde o início dos trabalhos, é instaurado o estado de música, em detrimento de um estado de prosa que levaria à racionalidade e ao 
uso do material corpo-mente-emoção no lugar acessado cotidianamente, portanto menos autônomo.

Com o objetivo de estabelecer uma estrutura musical para o próprio encontro, passamos a estabelecer uma sequência de exercícios, como uma partitura, dentro dos quais, após apropriação da própria sequência, os atores eram instigados a compor. Imaginamos uma partitura fixada nos seguintes compassos:

1. Ações de chegada ao espaço e ao encontro a partir de uma leitura proposta no encontro anterior

(trata-se da leitura de um material de estudo, não de texto dramatúrgico)

2. Respiração

(sequências de saudações - diversas - ou o dáctil ${ }^{168}$ )

3. Ativação do corpo-mente-emoção

(estímulos musicais, sem necessidade de utilização direta da música)

4. Jogos teatrais-musicais de provocação ao corpo e voz

(buscam colocar o ator no jogo teatral a partir de sua musicalidade, criando tensão entre ele e todo o material envolvido, que pode ser outro ator, a própria cena, iluminação ou cenário, por exemplo)

5. Investigações sobre o TEMA do encontro

(material selecionado sobre o qual se compõe, variando a cada encontro, ou em grupos de encontros)

6. Trabalho com texto ou roteiro de ações

(para trabalhar as relações tempo-espaço textuais e a musicalidade do prórpio texto em diálogo com as demais)

7. Espaço Musical Livre

(exercícios de escuta a partir de estímulos sonoros propostos pelos atores a partir dos estudos realizados até então)

8. Trocas

\footnotetext{
${ }^{168}$ Segundo a professora Yedda, é um momento de plena concentração, condensado num breve repasso psico-físico de todos os princípios biomecânicos. Vai do envolvimento do corpo inteiro, a partir do centro energético, desenrolando-se internamente. Há um ritmo preciso definido para a realização desse movimento, correspondente ao ritmo métrico dáctilo grego ( - ${ }^{u}$, uma longa e duas breves), vindo daí o nome dáctil. (informação verbal)
} 
(compreender a organização musical de cada encontro e dos conjuntos de encontros a partir de reflexões; momento do estado de prosa)

Com uma estrutura de encontros pré-estabelecida, mas nunca previamente explicada, os atores possuem maiores possibilidades de aprofundamento nas investigações, pois, ainda que racionalmente a sequência não tenha sido oficializada, o corpo já aprendeu isso, ganhando espaço para se dedicar ao trabalho em si e não à estruturação dele. Funciona realmente como uma grande partitura compassada, com todas as demais possibilidades de preenchimento em branco. Damos ao ator um material com o qual ele tem que trabalhar, isso o força a criar, a compor. E, como o estímulo é sempre fazer diferente, após preenchida inúmeras vezes pelos recursos já conhecidos, a partitura em branco saltará, desesperadoramente, aos sentidos do ator, que então não terá alternativa, já que na pode retomar o que já fez sem causar-lhe modificações, senão criar algo diferente.

A utilização de musicalidade do início ao fim dos trabalhos e, enquanto estrutura, dentro de cada "compasso" de trabalho, garantia que ela fosse incorporada, mesmo quando isso não era racionalmente percebido pelo ator. Alguns atores resistiam muito ao trabalho por esse motivo. Não conseguiam encontrar explicações organizadas no modo racional para essa sequência ou para alguns exercícios propostos dentro dela, então não conseguiam se entregar a eles. Com o passar dos encontros, a medida que o próprio corpo-mente-emoção passava pelo processo de incorporação da organização musical proposta, as resistências iam diminuindo e as investigações se intensificando, mesmo que no momento das trocas, o último compasso de cada encontro, as observações fossem feitas no sentido contrário. Isso mostra que muitas vezes o aprendizado se dá num nível e não no outro.

Mas há, ainda, outros elementos importantes trabalhos nesses encontros. Um deles é a dissonância. Muitas vezes conseguida pela polifonia, que não é, por si só, dissonante.

O trabalho buscava instigar cada ator a compor e, para isso, se tornar autônomo no seu fazer teatral. Isso era possível aguçando-Ihe a 
escuta e provocando-lhe a fala, ambas em sentido amplíssimo. Quanto melhor escuta o ator, mais é capaz de criar vozes. Isso era instigado a partir da forma, a partir dos exemplos de Meyerhold. "Ele não tinha medo de dar ao seu público mensagens conflitantes e usava esse confronto entre música e ação para manter o público alerta e conscientemente engajado na performance..169

Meyerhold, ligado sempre às vanguardas, fazia questão de dialogar com todas as linguagens de modo a torná-las parte da arte teatral e de aprender inovações a partir delas, de onde, buscou criar ainda mais dissonâncias e camadas em seus espetáculos.

Para ele, diferentemente do cinema, no teatro, "o ator e a música ocupam o mesmo espaço em uma relação viva e direta. Meyerhold estava interessado em explorar essa relação em seus treinos e suas performances. Fazendo isso estava, mais uma vez, se dirigindo do teatro naturalista para sua aliança com o teatro popular - o Drama Musical, o melodrama, o circo, a pantomima. Nessas formas, a música dá estímulos constantes à ação. Ela é parte da forma, não simplesmente outra camada junto com todo o resto." ${ }^{\text {"170 }}$

Finalmente, a compreensão de que toda ação cênica pode, para não dizer deve, ser composta a partir de três momentos musicalmente divididos, traz presença ao ator, uma vez que o coloca inteiro em cada etapa de cada ação a realizar. É como decupar o aqui e agora e alargar sua percepção. Estou falando do otkas, póssil e tochka, que podem ser pensados como prólogo, execução e epílogo.

Nos estudos realizados, qualquer material trabalhado deveria passar por esses três momentos, capazes de definirem ritmos para o ator. Otkaz, como já explicado, descreve a preparação de um ator antes de sua ação, por exemplo agachar antes de pular ou se debruçar para trás antes de lançar algo para frente. Póssil, deriva do verbo "enviar", em russo, é a ação em si. O pulo ou o lançar. Tochka marca o final do ciclo de uma ação, é a

\footnotetext{
${ }^{169}$ PITCHES. 2003. op. cit. p. 55-56 (tradução nossa com auxílio de Luiz Rodrigues)

${ }^{170}$ Idem ibidem, p. 57
} 
suspensão ao final de um movimento, sugerindo um novo começo, portanto o movimento não se encerra definitivamente.

A questão rítmica é central no trabalho do ator e do encenador. Ele dá forma e estrutura para tudo que se faz em cena. Deixar explicito a escolha rítmica faz a plateia acompanhar o movimento musical. Possuir domínio sobre o ritmo dá liberdade dentro de certos limites e estabelece uma linguagem a ser usada entre os atores e o diretor, mas principalmente, encarnar as questões rítmicas faz o ator pensar em termos musicais desde o início de qualquer trabalho.

O trabalho a partir da musicalidade é, antes de mais nada, uma forma de friccionar naturalmente tempo e espaço. Trabalhar as sonoridades no espaço, os movimentos no tempo e organizar musicalmente esse tempo-epaço, são conquistas que decorrem desse trabalho.

Um ator formado a partir de princípios musicais tem melhores condições de se conectar ao público, pois seu fazer está, por princípio, no lugar da música. Enquanto que um ator que inicia seu trabalho no lugar da prosa, precisa, no mínimo, de algum tempo utilizando o espaço, para criar conexões entre eles.

Esse é o principal exercício, entender que ao fazer parte da forma, não é necessário criar nela as brechas que permitem as conexões. Estas estão dadas. $E$ isso é possível a partir da musicalidade como eixo central na composição cênica do ator. 


\section{- 3o movimento: Conexões Polifônicas}

Um teatro fundado na música é uma proposta coerente uma vez que organiza todo o material teatral a partir de princípios musicais, conservando a multiplicidade de cada elemento colocado em jogo. A música é mais que uma das linguagens que compõem a cena, é o pensamento sobre o qual devem se deitar todas as ações cênicas.

Para se pensar musicalmente um teatro, não podemos nos render às necessidades de autoafirmação das linguagens. Respeitadas as peculiaridades de cada uma, elas coexistem. Não que a existência deva ser pacífica, mas que promova a fricção entre elas. É preciso que seja uma existência originariamente em fusão.

Arriscamo-nos aqui, a fazer um passeio a outra área do saber para emprestar o conceito jurídico de fusão. No Direito Empresarial ${ }^{171}$, fusão é a união de duas ou mais sociedades, para formar uma nova, com extinção das fusionadas.

Imagine agora que, para dar existência ao Teatro Musical, as diferentes linguagens que o compõe, por exemplo teatro, música, dança, circo e artes plásticas (a partir da iluminação, cenografia e design de aparência), abram mão da sua existência isolada e emprestem toda sua matéria para juntas construírem uma nova linguagem, possuindo como organizador a musicalidade inerente a todas elas. Não é uma retomada da ancestralidade da arte apenas, mas uma atitude em relação a ela que permite organizar os princípios de cada área específica de modo musical, com vistas a constituir algo múltiplo, dentro das multiplicidades, mas uno na essência.

Elencamos, a partir de Meyerhold, alguns elementos para que um Teatro Musical possa ser composto (item 4.3.), separando-os em

${ }^{171}$ Disciplina que leciono há 16 anos. 
fundamentais e pessoais, que repetimos a seguir com o intuito de relacionálos.

Os fundamentais, essenciais à estrutura complexa e variável das fricções musicais entre as linguagens que o compõe, são:

e) Música audível

f) Música inaudível

g) Polifonia

h) Fricção entre teatro, dança, música, artes plásticas e dramaturgia

Os pessoais, material humano essencial às composições que se darão nas relações estabelecidas e a se estabelecer a partir da composição do espetáculo:

f) Um ator musical;

g) Encenador musical, capaz de provocar os elos musicais das linguagens envolvidas;

h) Dramaturgia musical;

i) Formação a partir da musicalidade para os profissionais do Teatro;

j) Ressonâncias na plateia.

Como pressuposto de um Teatro Musical, a música estará presente, como já dissemos, audível e inaudível. Nesse sentido ela será recurso e fundamento. A música não ilustra ou reforça as ações, ele é a sua base, sua estrutura. Tudo é musicalizado: o texto, o gesto, o olhar, a iluminação.

Cada linguagem nesse teatro, fricciona para a construção dessa outra linguagem, polifônica, que se dará a partir das complexidades imanentes ao processo de composição, a partir de dissonâncias e consonâncias, mas com profundidade e muito tratamento estético. É como em 
Morin (Capítulo 1), exprimirá sua unimultiplicidade, isto é, será múltiplo, sendo apenas Teatro Musical.

Não se trata de instaurar uma nova via ao teatro, a terminologia Teatro Musical só deve prosperar enquanto útil para nos lembrar da relevância em se trabalhar o próprio Teatro a partir da musicalidade. Com isso queremos dizer que o Teatro é múltiplo, como também o são a Dança, a Música, as Artes Plásticas e todas as outras linguagens, mas é preciso, no mínimo, dois movimentos: o primeiro de reconhecer e passar a encarar essa multiplicidade na prática, o segundo de buscar uma organização a ela que não a retalhe, não a torne disjuntiva ou descontextualize. A musicalidade, pelo seu caráter universal de organizar tempo em espaços, é capaz disso.

Trouxemos, nos capítulos anteriores, inúmeros exemplos de utilização da musicalidade nesse sentido em Meyerhold, que podem servir como inspiração para novas investigações ou mesmo como fontes para nossa prática teatral diária. Mas há uns tantos outros encenadores que também utilizam-se da musicalidade dessa forma. Acrescentamos aqui, umas palavras de Ariane Mnouchkine, ao falar da presença de teatro, dança e música em seus espetáculos:

"A questão da presença e da aliança das artes irmãs no teatro, não existe mais para o Théâtre Du Soleil: já respondemos 'sim' há muito tempo. (...) para nós, é essencial: a música, o texto, o espaço, a luz e os corpos. È claro que os atores estão no centro do teatro, seja ele qual for. Mas sem música, sem luz, não seria o teatro de que gosto, mesmo que os atores sejam bons, mesmo que seja teatro. Muito rapidamente essa aliança se revelou necessária, e a questão colocada foi a seguinte: 'Como podemos realizá-la?' Mistério. 
Pra mim, um verdadeiro teatro - quero dizer espaço físico e as criações - é, antes de tudo, feito de encontros." ${ }^{172}$

E esse Teatro Musical, para existir, necessita dos elementos pessoais elencados acima: atores musicais, encenadores musicais, dramaturgia musical, formação a partir da musicalidade para todos os criadores em fricção e ressonâncias na plateia.

Há muito material para se investigar. Nos atendo apenas ao ator musical e sua formação, vimos quanto é imprescindível rigor e precisão no treinamento. Que este não pode ser apresentado como adestramento, pois buscamos emancipar o ator a partir da encarnação da musicalidade. E que, para isso, é necessário que o ator se desnude do repertório já conquistado, para constantemente agregar uma estrutura musical ao seu fazer artístico, a partir das fricções com os outros artistas da cena e em constante diálogo com o público.

O ator treinado irá desenvolver a percepção não apenas da própria musicalidade, mas das musicalidades em logo e, principalmente, daquela da plateia, com a qual poderá jogar, a fim de tocá-la. Neste sentido que podemos observar musicalidade nos desenhos plásticos e teatralidade no ritmo.

A relação entre o tempo e o espaço constitui uma das essências no trabalho do ator com a musicalidade. Ao incorporar essa relação, conectar-se com o jogo cênico e com o público no tempo e no espaço precisos. Ativando suas Inteligências para que dialogue não só na racionalidade, mas, principalmente, na afetividade e na pulsão, produzindo um resultado concreto não excluindo o público da arte. Cabe ao ator dominar esse jogo entre tempo e espaço, compondo musicalmente suas ações. Já disse Meyerhold:

\footnotetext{
${ }^{172}$ MNOUCHKINE, Ariane. Uma Obra de Arte Comum. Entrevista concedida a Béatrice Picon-Vallin em março de 1993. In PICCON-VALLIN. 2006. op. cit. p. 114-115
} 
"Não é na capacidade de refletir a plenitude da realidade, ou, dito de outra maneira, das representações e de suas transformações no tempo, que reside a arte. Ela decompõe o real utilizando tanto as formas espaciais quanto as formas temporais." 173

O trabalho é musical desde a origem e em cada micropartícula. A forma mais simples de se trabalhar isso é garantindo que cada movimento seja composto por, pelo menos, os 3 momentos musicalmente concebidos: otkas, posil e tochka. Temos que atribuir à palavra movimento o seu sentido amplo, equivalente a ação ou conjunto delas, assim um "inspirar" é um movimento, bem como "descascar uma cebola”, ou "seduzir alguém".

A partir disso e do fundamento da Biomecânica pelo qual movendo-se a ponta do nariz, o corpo todo se move, trazemos integralmente 0 corpo do ator para qualquer movimento. Se à menor tensão o corpo todo reage, isso ocorre na respiração, no descascar da cebola e no seduzir alguém. Desenvolve-se no ator a máxima consciência e precisão.

Essa estrutura possibilita mais que um novo olhar sobre a atuação, faz crer que o ofício do ator se dá em inúmeros planos. Sem disjunção entre carne, mente e espírito e rompendo, definitivamente, a quarta parede e todas as paredes que podem existir entre os componentes da criação cênica e o público.

A exigência de que a plateia passe a completar a obra, por ser o $4^{\circ}$ criador, provoca nela a reflexão e as reações ao que acontece em cena, já que a obra é inacabada. Isso ganha profundidade com o modelo de "teatro em linha reta", proposto por Meyerhold, com o objetivo de integrar os ofícios do autor, do encenador, do ator e a plateia. Neste modelo o ator revela sua alma ao espectador, após incorporar o trabalho do encenador, que já havia encarnado em suas ideias o trabalho do autor.

${ }^{173}$ MEYERHOLD. Do Teatro. Apud THAIS. 2009, op. cit. p. 343 
Longe de querer questionar 0 teatro proposto por Meyerhold, que implicou em gigantesca evolução e revolução no teatro ocidental que o sucedeu, arriscamos aqui sugerir um "Teatro em Círculo".

A partir da proposta de Meyerhold, em integrar todas as artes envolvidas no espetáculo e tendo vivido algumas experiências nesse sentido, tanto na montagem de espetáculos profissionais, quanto em ambiente acadêmico, orientando as montagens escolares (no melhor sentido da expressão, porque realizadas na escola), pudemos sentir que o Teatro, ao menos o paulista, está pronto para iniciar uma jornada de construção avançada nas ideias do mestre russo.

No Teatro em Círculo, todos os profissionais são fomentadores de todas as propostas, retroalimentando o mecanismo propositivo a partir das ações concretas que sucedam as propostas anteriores.

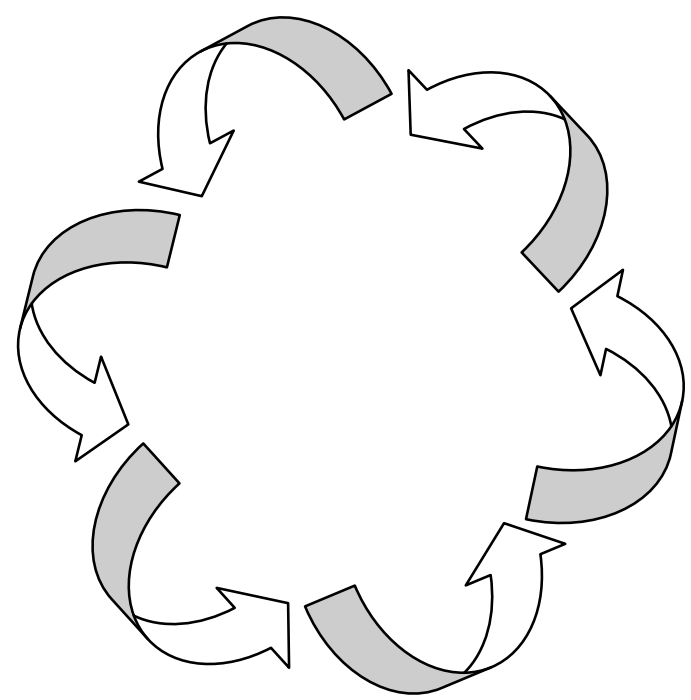

Não importa onde tem início a proposição criativa, ela sempre irá passar novamente em cada um dos criadores e, nessa passagem haverá fricção constante. Por exemplo, se a proposta parte da iluminação, será incorporada pela cenografia, depois pelos atores, depois pela sonoplastia, depois pela dramaturgia, depois pela direção, depois pelo design de aparência, chegando ao público, que em fricção com essa primeira proposta responde e 
essa resposta volta, já modificada, para a sonoplastia continuar propondo e manter o fluxo do movimento criador. Sequer a ordem dos profissionais precisa ser mantida. E mesmo o momento em que o público terá sua participação não é o mais importante, uma vez que os artistas também beberão nas reações dele.

Entendemos, que este modelo coloca a criação antes das linguagens. A organização do movimento é musical, cada volta completa encerra um movimento musical criador, mas o mais importante é que cada movimento seguinte é capaz de criar polifonias em relação aos anteriores, uma vez que interdependentes, já que gerados a partir uns dos outros.

Ainda que a sequência se inicie no modelo mais tradicional, a partir do texto, seguindo para o diretor, daí para os atores, cenógrafos, iluminadores, sonoplastas, figurinistas, a retomada da dramaturgia, quando a criação voltar ao texto, significará um novo olhar sobre o ele, ao mesmo tempo em que garante que não se esvaia no processo criador, pois é constantemente retomado.

Este modelo precisa ser entendido a partir da musicalidade, o que the garantirá uma organização na arte, e não na planilha racional. Pensado no estado de prosa, portanto fora do estado de música, sufoca o criador e emprega obrigações descabidas em se manter uma sequência meramente apreciatória. Isso conduz o retorno do teatro tão combatido por Meyerhold, onde a desarmonia entre todos os profissionais envolvidos no evento teatral, que não promovem os atritos necessários entre si para que componham um caminho polifônico de criação, faz com que cada profissional se confine em seu ofício, não encontrando no teatro papel além da subserviência.

É, realmente, difícil permitir ao homo demens o emprego de uma estrutura norteadora do evento teatral, mas a musicalidade irá dar a organização necessária para que todos, inclusive o público, se tornem criadores, sem que sejam obrigados a tal. Isso é fundamental, a estrutura em círculo coloca, na sequência da criação, aquele criador que esteja pronto a 
oferecer sua colaboração ao trabalho. Não há rigidez no conteúdo, apenas na forma. Isso garante principalmente três coisas essenciais ao Teatro Musical: que todos irão criar, que a criação receberá diversos olhares transformadores de cada agente criador e que o público fará parte da criação, portanto o espetáculo não estará pronto, já que bebe também na possibilidade criadora do público.

Agora se faz necessário compreender que não estou colocando o público enquanto criador artístico. Essa responsabilidade não é dele. Tampouco impinjo-Ihe a função participante como em Brecht. O sentido desse criador, que não sabemos mais se será o $4^{\circ}$ ou o $8^{\circ}$, é meyerholdiano, ou seja, o de completar a obra, de inserir nela, por si e para si, elementos que ficaram de fora, exatamente para que ele pudesse fazer isso. Com essa tarefa dada ao público, estabelecem-se outras aos demais criadores. Os atores atentos às conexões diretas estabelecidas e os outros às ações e reações que signifiquem material para a continuidade da criação.

Isso evitaria que espetáculos ficassem em cartaz tantos anos em estado de inércia, sem que sejam alterados por qualquer dos criadores, pois instaura a obrigação artística de um olhar sobre o público para que este faça parte do processo criador. A proposta é não olhar mais para o público enquanto massa.

Este é um teatro que cria polifonias vivas, instigando os criadores artísticos em seus ofícios a aprofundar suas artes, sempre em relação a elas mesmas e a todas as demais, considerando o público.

Finalmente, queremos abordar a questão da formação do ator a partir dos elementos aqui levantados.

O ator musical estará presente sempre que, desde o processo criativo e até as apresentações para qualquer plateia, o ator possa escolher a variação de tempo-ritmo, alturas e andamentos em suas ações cênicas, propondo e executando uma musicalidade, quer para a peça, quer para determinadas cenas, ou até para um conjunto de falas, deixando o lugar 
comum, passando a reger sua produção cênica e possibilitando conexões com o público.

No entanto, como já alertou Bonfitto (2002), não há nos programas de formação do ator um componente sequer que corresponda a "composição" ou a "musicalidade da interpretação". Então como possibilitar a pesquisa a partir da musicalidade? $\mathrm{O}$ ator trabalha com diferentes texturas, às quais ele deve dar sentido e unidade. Esta só poderá emergir do diálogo entre o fazer e o pensar o fazer. Um transformando ao outro, sucessiva e constantemente, gerando um espiral no qual se move o ator-compositor.

"A composição no trabalho do ator, assim como em outras formas de arte, coloca em evidência os aspectos palpáveis de seu ofício. Porém, ela não deve ser resultado de uma operação somente intelectual. A verdadeira composição é aquela que imprime inexoravelmente uma experiência, mas não expões as razões de suas escolhas. Deixa somente rastros..."174

Os pressupostos encontrados nas obras de Meyerhold e outros mestres nos guiaram a levantar as questões postas, requerendo uma investigação continua que possibilite o aprimoramento em nosso "fazer" e em nosso "pensar o fazer". As bases conquistadas junto a professora Yedda, nos colocam prontos a enfrentar essas questões e a rica tessitura constituída a partir da poética de Meyerhold, nos permite pensar o teatro de modo abrangente e polifônico.

Uma formação do ator, contextualizada neste lugar e levando em conta sua multiplicidade e a necessidade de que seja global, abordando todos os elementos de seu trabalho em fricção, e capaz de promover a experiência, é um caminho ainda a ser trilhado, mas que felizmente encontra acalento em poucos mas fortes braços de pessoas e instituições que acreditam num ator emancipado.

${ }^{174}$ BONFITTO. 2002. op. cit. p. 143 


\section{REFERÊNCIAS}

ABENSOUR, Gerard. Vsevolod Meyerhold ou a Invenção da Encenação. Trad. J. Guinsburg. São Paulo: Perspectiva, 2011

ADORNO, Theodor W. Filosofia da Nova Música. Tradução Magda França. 3 ed. São Paulo. Perspectiva, 2009

APPIA, Adolphe. A obra de arte viva. (Tradução e notas de ensaio de Redondo Jr.). Lisboa: Arcádia, 1919.

ASLAN, Odette. O ator no século XX. S. Paulo: Perspectiva, 1994.

BAUMAN, Zygmunt. Tempos Líquidos. Tradução Carlos Alberto Medeiros. Rio de Janeiro. Zahar, 2007.

BONFITTO, Matteo. O Ator Compositor: ações físicas como eixo: de Stanislavski a Barba. São Paulo. Perspectiva. 2002.

CAMPOS, Haroldo de. Metalinguagem e outras Metas. SP, Perspectiva, 1992.

CARRIRA, André \& NASPOLINI, Marisa (organizadores) e outros. Meyerhold: Experimentalismo e vanguarda. Rio de Janeiro. E-papers, 2007.

CAZNOK, Yara Borges. Música: entre o audível e o visível. 2 ed. São Paulo: Editora UNESP; Rio de Janeiro: Funarte, 2008

CHAVES, Yedda Carvalho. A Biomecânica como princípio constitutivo da arte do Ator. Dissertação de mestrado do Centro de Artes Cênicas da Escola de 
Comunicação e Artes da Universidade de São Paulo (CAC/ECA/USP), São Paulo, 2001.

CINTRA, Fabio. A Musicalidade como Arcabouço da Cena. Tese de Doutorado. CAC/ECA/USP. São Paulo, 2006.

FONTERRADA, Marisa Trench de Oliveira. O Lobo no Labirinto: uma incursão à obra de Murray Schafer. São Paulo: Editora UNESP, 2004.

GUINSBURG, Jacob. Stanlislávski, Meierhold \& Cia. Perspectiva. São Paulo, 2001

KOUDELA, Ingrid Dormien. Jogos Teatrais. São Paulo. Perspectiva, 2006 . Texto e Jogo. São Paulo. Perspectiva, 1999 . Brecht na pós-modernidade. São Paulo. Perspectiva, 2001

LASSALE, Jacques \& RIVIÈRE, Jean-Loup. Conversas sobre a formação do ator. Trad. Nathalia Rabczuk. São Paulo: Perspectiva, 2010.

LASZEN, Ludwik e BARBA, Eugênio. O Teatro Laboratório de Jerzy Grotowski 1959-1969 / textos e materiais de Jerzy Grotowski e Ludwik Laszen com um escrito de Eugênio Barba, curadoria de Ludwik Flaszen e Carla Pollastrellip com a colaboração de Renata Molinari, Tradução para o português de Berenice Raulino. São Paulo. Perspectiva: SESC, Pontedera, IT: Fondazione Pontedera Teatro, 2007.

LEACH, Robert. Stanislaviski and Meyerhold. European Academic Publishers, Berlim: 2003 
LONDRÉ, Felica Hardison. Word Theater. New York, USA, Frederick Book, 1991

MARTINS, J. B. Dal Farra. Percusos Poéticos da Voz. Revista Sala Preta. N.7. Dossiê Voz. São Paulo: CAC-ECA-USP, 2007.

MEYERHOLD. Vsévolod. O Teatro Teatral. Trad. Redondo Júnior. Lisboa: Ed Arcádia, 1980

MEYERHOLD, Vsévolod. Do Teatro. Trad. Diego Moschkovich. São Paulo: lluminuras, 2012

MORAES, Maria Cândida \& ALMEIDA, Maria da Conceição (organizadoras). Os sete saberes necessários à educação do presente: por uma educação transformadora. Rio de Janeiro: Wak Editoras, 2012

MORIN, Edgar. Os Sete Saberes Necessários à Educação do Futuro. 3 ed. Cortez, UNESCO, Brasília, 2001

PAVIS, Patrice. Dicionário de teatro. S. Paulo, Perspectiva, 1999. A Análise dos Espetáculos. Perspectiva. São Paulo, 2010.

A Encenação Contemporânea: origens, tendências, perspectivas. Trad. Nanci Feranandes. São Paulo: Perspectiva, 2010.

PICON-VALLIN, Béatrice. A Cena em Ensaios. Perspectiva, São Paulo, 2008. A Arte do Teatro: entre tradição e vanguarda: Meyerhold e a cena contemporânea. Org. Fatima Saad. Rio de Janeiro. Teatro do Pequeno Gesto: Letra e Imagem, 2006. 
A Música no jogo do Ator Meyerholdiano. IN In Le jeu de l'acteur chez Meyerhold et Vakhtangov. Paris: Laboratoires d'études théâtrales de l'Université de Haute Bretagne. 1989. Tradução de Roberto Mallet.

PITCHES. Jonathan. Vsévolod Meyerhol. London: Routledge, 2003

SCHAFER, Murray. O Ouvido Pensante. Ed UNESP, São Paulo, 2002 A Afinação do Mundo. Ed UNESP, São Paulo, 2001

SILVA, Armando Sérgio da Interpretação: uma oficina da essência. Tese de livre docência do Departamento de Artes da Escola de Comunicação e Artes da USP. São Paulo, 1999

SPOLIN, Viola. Jogos Teatrais: o fichário de Viola Spolin. Tradução Ingrid Dormien Koudela. 2 ed. São Paulo. Perspectiva, 2006

THAIS, Maria. Na cena do Dr. Dapertutto: poética e pedagogia em V. E. Meierhold. Perspectiva: FAPESP. São Paulo, 2009.

WISNIK, José Miguel. O Som e o Sentido: uma outra História das Músicas. São Paulo: Cia das Letras, 1989

Revista Sala Preta Números 5 e 7 - Publicação do Programa de PósGraduação em Artes Cênicas da Escola de Comunicações e Artes da USP. 


\begin{abstract}
ANEXO A
Fragmento do texto "Casa de Bonecas" de Ibsen utilizado para exemplificar algumas diferenças entre uma interpretação Naturalista e um interpretação Estilizada, segundo a obra XXXXXXX de Yyyyyyy..., conforme nota de rodapé número 61 :
\end{abstract}

NORA: Oh, sente-se e toque pra mim, Torvald, querido. Corrija-me, guie-me, do jeito que você sempre faz.

HELMER: Muito bem minha querida, se você deseja isso.

Ele senta-se ao piano. NORA pega o tamborim e um xale multicolorido da caixa, enrola o xale apressadamente, então vai o mais rápido que pode ao centro da sala e chora.

NORA: Toque para mim, eu quero dançar.

HELMER toca e NORA dança.

DR. HANK fica logo atrás HELMER ao piano assistindo

HELMER: Mais devagar, devagar!

NORA: EU não consigo.

HELMER: Não seja bruta, Nora.

NORA: EU devo!...

RANK: Deixe-me tocar para ela...

RANK se senta ao piano e toca. NORA dança de modo cada vez mais selvagem. HELMER para próximo ao aquecedor e tenta repetidamente corrigila, mas ela tenta não ouvi-lo. Seu cabelo está solto e cai sobre os ombros, ela ignora isso e continua dançando. 


\begin{abstract}
ANEXO B
RESUMO DO PROJETO DE ESTUDOS COM O GRUPO DE 5 ATORES

Trabalho realizado junto ao CEPECA (Centro de Pesquisa e Experimentação

Cênica do Ator)
\end{abstract}

Orientação: Professor Armando Sérgio da Silva

Coordenação: Carlos Eduardo Witter

Atores-pesquisadores: Leticia Chiocheta, Lívia Figueira, Luiz Rodrigues, Nathaly Matsuda, Raoni Pereira

A partir das influências dos estudos desta disciplina, busquei com meu grupo de pesquisas um contexto onde trabalhar as novas descobertas e as fundamentações encontradas para questões antigas.

Construiremos um espetáculo a partir dos estudos que unam Meyerhold e Shaffer, abordando seus conceitos e práticas, falando da superexposição da mídia e a massificação da sociedade de consumo produziram seres completamente alienados e dependentes das indicações dos meios de comunicações em geral sobre o que podem ou devem fazer.

\title{
a) Sinopse
}

O Sr. F, quer ser o Sr. X, usar seu chapéu, ter uma mulher e um carro como os dele, sonha em ter seus olhos azuis e viver sua vida.

Mas um belo dia dá um "chute no patrão" e se liberta dos mecanismos que conduziam sua vida passando a atuar para a "libertação" de toda a população, nos padrões e modelos que experimentou para si próprio, impondo-os aos demais. 
Esse Justiceiro, "salva" a população de uma cidade inteira, permitindo que a partir de então todos possam tomar os rumos de sua vida, sem ninguém para dizer o que devem ou podem fazer.

No entanto, para seu espanto, as pessoas não se acostumam a essa "nova" vida e sentem-se desamparadas sem a ação de uma força a conduzi-las, até que um dia se revoltam contra seu libertador e passam a exigir dele o suprimento para continuar suas vidas.

Essa é a história de Kaus Mutantis, inspirada nas músicas "Senhor F" e "Justiceiro" da banda Mutantes, que ainda conta com cenas inspiradas na obra "Kaos", de Millor Fernandes, capazes de escancarar as fragilidades da contemporaneidade para quem quiser ouvi-las, vê-las e senti-las

Pavis diz que "aplicados ao teatro, a ação e o corpo do ator se concebem como o amálgama de um espaço e de uma temporalidade - e citando Merleau-Ponty - que o corpo não está apenas no espaço, ele é feito de espaço - e, feito de tempo"175.

Partiremos de exercícios a partir de Shaffer que permitem maior amplitude na experimentação alindo-os aos princípios da Biomecânica, para construir cenas que contenham, por exemplo, paisagens sonoras, rastros, acentos e pausas, mas principalmente pautadas em musicalidade.

Desta forma, quase tudo que envolve movimento produz som e ele pode ser organizado segundo diferentes tempos, ritmos e pulsos. Se nos preocupamos com o visual na composição de uma cena, devemos, também, cuidar da sonoridade, o que inclui o cuidado com a movimentação cênica segundo variantes determinadas de acordo com o efeito que se deseja produzir.

${ }^{175}$ PAVIS, Patrice. Dicionário de teatro. S. Paulo, Perspectiva, 1999. 
Pretendemos a partir do corpo sua própria ressignificação, uma vez que quando trabalhamos parte do corpo, podemos perceber que para modificar o todo, certas vezes, basta um tratamento diferenciado para uma parte dele.

Esses são conceitos fundamentais, pois a organização do movimento no espaço, diz respeito à musicalidade da cena e isso compõe a paisagem cênica, sendo o ator parte integrante, viva e geradora dela. Assim o ator é o centralizador do acontecimento teatral, onde se encontram tempo e espaço para expressar a cena.

\section{b) Procedimentos}

Partiremos dos anteparos e da estrutura proposta pelo professor Dr. Armando Sergio da Silva ${ }^{176}$, esquematizada em três momentos, para o trabalho do ator:

a) Ação: consiste em desvendar o objeto

b) Impressão Digital: criar o objeto pelo corpo e mente do ator

c) Composição dos Signos: transformar esse objeto em um signo articulado para a percepção do espectador

Anteparo designa tudo aquilo que o ator pode utilizar para se resguardar ou proteger. O objetivo é retardar a experimentação cênica por vários meios como a música, o canto e a dança, que serão muito utilizados nessa pesquisa, mas também por meio de narrativa, artes plásticas etc., de forma que o ator se dispa de uma criação muito racional e permita-se experimentar outras vivências.

Percebemos a importância da concentração e da habilidade em fazer música com o próprio corpo, "a frase do movimento constitui em si um esquema rítmico, ao mesmo tempo em que possibilita ao ator encontrar variações rítmicas - esses não devem constituir um movimento

${ }^{176}$ DA SILVA, Armando Sérgio. Interpretação: uma oficina da essência. Tese de livre docência do Departamento de Artes da Escola de Comunicação e Artes da USP. São Paulo, 1999, p36. 
artificial (...). Os movimentos mantém o espetáculo visível continuamente em vida. E para que a animação do corpo não seja a junção de suas partes em movimentos rítmicos, e nem mesmo a composição de percepções anônimas, o ator deve saber encontrar uma razão dentro de um contexto, dentro da dramaturgia, para então construir o gesto"177

Utilizaremos a música e a musicalidade a partir do texto e daquilo que cada ator pretende dizer com ele para a composição de partituras físicas (do corpo, da voz e do corpo e da voz) para então preenchelos de forma a criar dissonâncias e ressonâncias, além de polifonias.

A MUSICALIDADE no trabalho do ator deve ser compreendida a partir de três vertentes:

a) Do tempo-ritmo e da musicalidade do movimento

b) Da musicalidade gerada pelo ator a partir de seu repertório

c) Da influência da música e da musicalidade (enquanto fatores externos) como instrumentos de criação para o ator

O tempo-ritmo pode ser trabalhado em seus âmbitos interno e externo, com variações diferentes para cada personagem ou a mesma para toda a cena, a partir da utilização de sistemáticas desenvolvidas por Stanislaviski e Meyerhold, entre outros. Neste mesmo trabalho podemos inserir a questão da musicalidade do movimento, uma vez que o movimento também possui tempo-ritmo. Assim, o cair de um lenço no chão pode ser "musicado" uma vez que a ação de largá-lo afeta diretamente o tempo que leva e o modo como cai no chão, além da sonoridade que provoca, portanto o movimentação do ator influencia diretamente na musicalidade de uma microcena ${ }^{178}$ como esta.

O ator, enquanto criador e executor da encenação, é produtor natural da sonoridade que permeia a cena. Muitas vezes, sem a

\footnotetext{
${ }^{177}$ CHAVES, Yedda Carvalho. A Biomecânica como princípio constitutivo da arte do Ator. Dissertação de mestrado do Centro de Artes Cênicas da Escola de Comunicação e Artes da Universidade de São Paulo (CAC/ECA/USP), São Paulo, 2001, p. 168

178 DA SILVA, Armando Sérgio. Interpretação: uma oficina da essência. Tese de livre docência do Departamento de Artes da Escola de Comunicação e Artes da USP. São Paulo, 1999
} 
devida consciência, cria sonoridades interessantes que passam ou não a compo-la. A proposta é conscientizá-lo desta produção e muni-lo de instrumentos capazes de fomentar uma produção consciente que possa enriquecer sonoramente a produção cênica. Essa consciêntização vai além das sonoridades, uma vez que a musicalidade está, também, no gesto, isto pois o mero caminhar produz som que pode ser aproveitado para desenhar intenções e então passaremos a cuidar da intensidade da pisada, do tipo de sapatos a serem usados, da largura das passadas e do tempo de silêncio entre elas, por exemplo.

$\mathrm{Na}$ terceira vertente pretendemos utilizar a música como influenciadora de estados internos e externos capazes de instaurar no ator um resultado cênico. Ao ouvir uma determinada música o ator tem em si despertadas uma série de reações que podem, ou não, serem utilizadas na cena, mas certamente contribuem na composição da personagem. Essa utilização como anteparo na criação cênica, traz a música e a musicalidade como produtores diretos da geração cênica.

Para que o trabalho seja realizado e já que escolhemos que os atores não fossem necessariamente músicos ou dançarinos, iniciaremos um trabalho de conscientização e desenvolvimento de sonoridades, ampliando o repertório e possibilitando a criação individual e coletiva. Isto se dará por meio de "jogos teatrais musicais".

O jogo não é mero procedimento, mas metafísico. O teatro é jogo e se conseguirmos um nível de sofisticação e detalhamento adequados poderemos construir um espetáculo com musicalidade conscientemente elaborada pelos atores.

Existem diversos tipos distintos de jogos, dentre eles os musicais e os teatrais. No universo da música os jogos teatrais são utilizados como preparo do profissional que deve possuir certa desenvoltura e muita criatividade. O jogo musical, a princípio, não é simbólico. No universo do teatro, os jogos musicais auxiliam no desenvolvimento sonoro e no desapego à necessidade de expressão pela fala cotidiana. Buscaremos desenvolver 
JOGOS MUSICAIS TEATRAIS, que permitirão aos atores o desenvolvimento de suas habilidades musicais e consciência da musicalidade da cena.

A partir daí passaremos a desenvolver cada personagem e cada cena, provocando no ator sua musicalidade própria ao mesmo tempo em que impondo uma musicalidade comum, que estará presente na cena, assim definiremos ritmo, intensidade, acentuações, dinâmica, tessitura e sonoridades com a consciência de quem está regendo o espetáculo teatral, alternando-as ou repetindo-as propositadamente para melhor identificação de seus efeitos.

Aliaremos o exercício dos princípios básicos da biomecânica constantes na dissertação da professora Dra Yedda Chaves (págs. 49 a 65), partindo do aquecimento proposto nesta disciplina (a partir dos pés) que já estabelece relação do ator com o espaço produzindo musicalidade.

Nosso propósito é, ao libertar a musicalidade do ator, que ele fique à vontade para criar, a partir de sua consciência sonora e da intangibilidade que é inerente á música, qualquer personagem ou cena, pois o repertório conquistado a partir dos jogos teatrais musicais é geral e pode ser aplicado independentemente dos fatores determinantes do espetáculo a ser montado, uma vez que diz respeito à consciência do ator das três vertentes a serem desenvolvidas.

O ator musical, portanto, estará presente sempre que, desde o processo criativo e até as apresentações para qualquer plateia, o ator possa escolher a variação de tempo-ritmo, alturas e andamentos em suas ações cênicas, propondo e executando uma musicalidade, quer para a peça, quer para determinadas cenas, ou até para um conjunto de falas, deixando o lugar comum, passando a reger sua produção cênica e possibilitando conexões com o público. 


\title{
ANEXO C - APRESENTAÇÃO DA PESQUISA NO TUSP \\ A MUSICALIDADE COMO ELEMENTO CENTRAL NA COMPOSIÇÃO CÊNICA DO ATOR
}

\author{
Pesquisa Livre
}

\section{Sinopse}

\section{Sobre a pesquisa}

Este espetáculo nasceu de uma pesquisa realizada pelo pesquisador prof. Carlos Eduardo Witter, no CEPECA da USP a partir da musicalidade como eixo central na composição cênica do ator, buscando fontes de estudos em Meyerhold e Murray Shaffer.

Para que esta pesquisa se tornasse possível foram convidados atorespesquisadores que além de participar do Centro, fossem professores de artes, para que o processo resultasse da fricção entre a aplicação artística e a pedagógica dos procedimentos e experimentações realizados.

\section{Sobre o espetáculo}

A passividade e o deslumbramento da sociedade fizeram com que o homem deixasse de perceber o contexto social, político e econômico que vive. $\mathrm{O}$ grande avanço tecnológico impulsionou o indivíduo ao individualismo, com toda a interatividade eletrônica substituindo a interatividade com o ser humano.

Lidar com o ser humano não é simples e o homem gosta de gastar seu tempo com os aparelhos tecnológicos, controlando-os e "personalizando-os" para que fiquem mais parecidos consigo mesmo.

A mídia, com sua sedução e manipulação faz com que todos se sintam senhores do seu destino a partir das escolhas que ela faz. O homem se perde em si mesmo até descobrir-se capaz de fazer outras escolhas. Mas será que ele quer escolher diferente? O que faria uma sociedade com poder de decisão sobre si mesma? Cairíamos num novo processo de sedução e manipulação?

Em meio a essa temática, o público acompanha a história do Senhor F, e poderá escolher o destino deste personagem. Mas será uma escolha livre? 


\section{Ficha Técnica:}

Direção e Pesquisa: Carlos Eduardo Witter

Orientação: prof. Dr. Armando Sérgio da Silva (CEPECA / USP)

Elenco: Cadu Witter, Luiz Rodriguez, Nathaly Matsuda, Lívia Figueira, Letícia Chicocheta

Músico: Rodrigo Cruz

Interlocução: Centro de Pesquisa e Experimentação Cênica do Ator (CEPECA/USP)

Realização: Cia. Kaus Mutantis

\section{Necessidades Técnicas:}

Operação de luz, som e projeção

1 amplificador para guitarra

1 projetor

Luz básica 
ANEXO D

ALGUNS EXERCÍCIOS PROPOSTOS PARA OS ATORES NA INVESTIGAÇÃO DA MUSICALIDADE DO CORPO-MENTE-EMOÇÃO

- setembro de 2010

\section{Improvisações rítmicas a partir da música dos Mutantes:}

Bat Macumba ê ê, Bat Macumba obá

Bat Macumba ê ê, Bat Macumba obá

Bat Macumba ê ê, Bat Macumba obá

Bat Macumba ê ê, Bat Macumba obá

Bat Macumba ê ê, Bat Macumba oh

Bat Macumba ê ê, Bat Macumba

Bat Macumba ê ê, Bat Macum

Bat Macumba ê ê, Batman

Bat Macumba ê ê, Bat

Bat Macumba ê ê, Ba

Bat Macumba ê ê

Bat Macumba ê

Bat Macumba

Bat Macum

Batman

Bat

$\mathrm{Ba}$

Bat

Bat $\mathrm{Ma}$

Bat Macum

Bat Macumba

Bat Macumba ê

Bat Macumba ê ê

Bat Macumba ê ê, Ba

Bat Macumba ê ê, Bat

Bat Macumba ê ê, Batman

Bat Macumba ê ê, Bat Macum

Bat Macumba ê ê, Bat Macumba

Bat Macumba ê ê, Bat Macumba oh

Bat Macumba ê ê, Bat Macumba obá 


\section{ALGUNS ENCONTROS QUE TRABALHARAM A ESCUTA}

- 06 de outubro de 2010

1. Ativação:

Primeira Etapa

a. Caminhando com foco na respiração (Ouça sua respiração);

b. Quando eu bater uma palma gritam "Rá";

c. Quando eu estalar os dedos: Pulam;

d. Quando bater duas palmas: sentam, levantam e continuam a andar;

e. Quando eu disser "um" emitem um som muito agudo;

f. Quando eu disse "dois" emitem um som muito grave.

\section{Segunda Etapa}
a. Idem
b. "Rá" e fazem uma sonoridade com o próprio corpo;
c. Pulam e batem palma com o colega
d. Palmas, fazem sonoridade no chão, levantam e continuam
e. Agudo trocando olhar com outra pessoa do grupo
f. Grave trocando olhar com outra pessoa do grupo

\section{Ouvir a si mesmo}

\section{Primeira Etapa:}

Imediatamente após o exercício, sentam no chão e ficam sem se movimentar com os olhos fechados

OUÇA

Conversa sobre o que ouviram

\section{Segunda Etapa:}

Escute o coração, a respiração, a corrente sanguínea e todos os sons que você emite.

\section{Ampliando a escuta}

Exercícios híbridos a partir de Schafer e Viola Spolin

\section{Primeira Etapa:}


Sentados, de olhos fechados, devem ouvir o mais distante possível

$\rightarrow$ Conversa sobre o que ouviram

\section{Segunda Etapa:}

Devem alternar ouvir o mais distante e o mais próximo possível

$\rightarrow$ Conversa

\section{Terceira Etapa:}

Sentados, de olhos fechados. Ouvir o mais próximo e o mais distante possível, emitir sonoridades.

$\rightarrow$ Conversa sobre a qualidade do que ouviu

\section{Escuta ativa com interação e produção sonora}

Escutar a música "NYATITI" de Gregor Thelen, do CD "A música da África", coleção Azul music.

Instrucõoes antes de começar a música:

Ouça e identifique as sonoridades

Instruções durante a música:

Percebam como as sonoridades ecoam em você.

Onde elas tocam?

Quais os efeitos?

\section{Após alguns minutos:}

Permita que seu corpo se transforme a partir dos estímulos sonoros que você esta recebendo.

Sua voz também é parte do seu corpo, permita que ela se manifeste.

Ao final da música, permita que os atores permaneçam mais algum tempo no que estão fazendo.

\section{Construção de Sonoridades}

A partir da leitura da cena 6, "Tevê", da peça KAOS de Millor Fernandes, devem criar o ambiente sonoro. 
- 10 de outubro de 2010

1. Aquecimento:

Primeira Etapa

a) Caminhando com foco na respiração (Ouça sua respiração);

b) Quando eu bater uma palma gritam "Rá";

c) Quando eu estalar os dedos: Pulam;

d) Quando bater duas palmas: sentam, levantam e continuam a andar;

e) Quando eu disser "um" emitem um som muito agudo;

f) Quando eu disse "dois" emitem um som muito grave.

\section{Segunda Etapa}
a) Idem
b) "Rá" e fazem uma sonoridade com o próprio corpo;
c) Pulam e batem palma com o colega
d) Palmas, fazem sonoridade no chão, levantam e continuam
e) Agudo trocando olhar com outra pessoa do grupo
f) Grave trocando olhar com outra pessoa do grupo

\section{g. Ouvir a si mesmo}

\section{Primeira Etapa:}

Imediatamente após o exercício, sentam no chão e ficam sem se movimentar com os olhos fechados

\section{OUÇA}

Conversa sobre o que ouviram

\section{Segunda Etapa:}

Escute o coração, a respiração, a corrente sanguínea e todos os sons que você emite.

\section{h. Ampliando a escuta (VER VIOLA SPOLIN)}

\section{Primeira Etapa:}

Sentados, de olhos fechados, devem ouvir o mais distante possível

$\rightarrow$ Conversa sobre o que ouviram 


\section{Segunda Etapa:}

Devem alternar ouvir o mais distante e o mais próximo possível

$\rightarrow$ Conversa

\section{Terceira Etapa:}

Sentados, de olhos fechados. Ouvir o mais próximo e o mais distante possível, emitir sonoridades.

$\rightarrow$ Conversa sobre a qualidade do que ouviu

\section{i. Escuta ativa com interação e produção sonora}

Escutar a música "NYATITI" de Gregor Thelen, do CD "A música da África", coleção Azul music.

Instruções antes de começar a música:

Ouça e identifique as sonoridades

Instruções durante a música:

Percebam como as sonoridades ecoam em você.

Onde elas tocam?

Quais os efeitos?

Após alguns minutos:

Permita que seu corpo se transforme a partir dos estímulos sonoros que você esta recebendo.

Sua voz também é parte do seu corpo, permita que ela se manifeste.

Ao final da música, permita que os atores permaneçam mais algum tempo no que estão fazendo. 


\section{ALGUNS ENCONTROS SOBRE CONCEITOS MUSICAIS}

- 13 de outubro de 2010
1. Grita "AH"
2. 2 batidas de pé
3. 3 estalos de dedo
4. 4 batidas de palma

Trabalhar com diferentes seqüências.

2. Construir a Sonorização de Alguns lugares

Idéias possíveis: Marginal, Usina de petróleo, Biblioteca, praia.

\section{Aquecerem-se distribuídos pelo espaço físico e sonoro de forma uniforme}

Fazem alongamentos, exercícios vocais e aquecimento de voz e corpo preenchendo todo o espaço.

Pesquisar:

a. Alternância de silêncio e som;

b. Ruídos (que ouvem e produzem);

c. Conscientização do timbre de voz;

d. Estabelecer dinâmicas de amplitude

e. Criar texturas

4. Dialogar com a música, preenchendo o espaço sonoro

a. Usar a música dos Andes alternando a dinâmica (forte e fraco) entre ela e as sonoridades produzidas.

b. Utilizar a música a ser trabalhada na cena "Batmacumba" e "Ando meio desligado" dos Mutantes, estabelecendo as mesmas dinâmicas (fizeram uma vez a cena - direto)

5. Construir a sonoridade do texto a ser trabalhado

6. Passar o texto falado (2 vezes)

7. Passar o texto falado cantando a música no momento da fala (2 vezes)

8. Passar o texto falado com os dois estados obtidos nos itens 5 e 6 (2 vezes) 
- Novembro de 2010

1. Em círculo, 1 passa gesto e som para o outro, que deve repassar outro gesto e outro som

2. Sonoridade vem do movimento

3. Movimento vem da sonoridade

4. Reconstruir a sonoridade do texto

5. Passar mais um vez o texto, ambientando- o na sonoridade construída como paisagem no exercício anterior

6. Passar o texto cantando a música "BATMACUMBA" no lugar das falas (2 vezes)

7. Passar o texto com a fusão dos dois estados obtidos (4 e 6)

- 12 de Janeiro de 2011

1. Retomada dos Conceitos com Exemplos

2. Ativação

3. Diálogos com a Amplitude: Corpo, Olhar, caminhos

a. Do Fraco $\rightarrow$ Forte $\rightarrow$ Fraco $\rightarrow$ Silêncio

b. Do Grave $\rightarrow$ Agudo $\rightarrow$ Grave $\rightarrow$ Ruídos

c. Do curto $\rightarrow$ Longo $\rightarrow$ Curto $\rightarrow$ Silêncio

d. Dinâmicas das sonoridades

4. aplicar descobertas:
a) à respiração
b) Ao olhar
c) Às articulações
d) Ao caminhar
e) Aos orifícios do corpo
f) À relação com o outro

5. Aplicar as descobertas ao texto. 
- Fevereiro de 2011

(UTILIZANDO AS DINÂMICAS DO SOM NO CORPO)

1. Aquecimento físico e Vocal

2. Em duplas, experimentam diálogos corporais e sonoros a partir dos estímulos Grave/ agudo, Forte/ Fraco, Longo/ Curto;

3. Vivenciando o Grave/ Agudo

a. caminhando: Ao comando "grave", emitem sonoridade grave e buscam transportar esse comando para o corpo (“Como é o grave no corpo?")

b. Idem para o agudo

4. Vivenciando o FORTE/ FRACO

a. Repetição do exercício anterior

5. Vivenciando o LONGO/ CURTO

a. Repetição do anterior

6. Aplicam na cena (Cena 8 - KAOS)

Obs.: Função do "Deixar-se levar" no Batmacumba e little Spaced out 
- Março de 2011

(VIVENCIANDO AS DINÂMICAS DO SOM NO CORPO)

1. Aquecimento Físico e Vocal

2. Experimentar no corpo a partir das sonoridades que produzem, as dinâmicas:
a. Agudo
b. Agudo e forte
c. Agudo e fraco
d. Grave e forte
e. Grave e fraco
f. Grave, fraco e longo
g. Grave, fraco e curto
h. Grave, forte e longo
i. Grave, forte e curto
j. Agudo, fraco e longo
k. Agudo, fraco e curto
I. Agudo, forte e longo
m. Agudo, forte e curto

1. Apropriaçãoda experimentação a partir de composições livres

2. Cenas 
- Março de 2011

(PERMITINDO A AÇÃO DAS DINÂMICAS DO SOM NO CORPO PELO PROLONGAMENTO DA AÇÃO)

1. Aquecimento físico e vocal

2. Desenho no ar com associações entre o movimento e as sonoridades

Ex. Quanto mais alto mais agudo/ quando mais baixo mais grave.

(apenas como estímulo inicial pode se inverter dentro do jogo)

3. Inserir os elementos da dissonância (Forte; fraco e Longo e curto) do exercício 2, após a apropriação pelo corpo do grave/agudo

4. Expressar o grave no corpo ( e na voz) prolongando sua utilização até o limite (dar instruções durante o exercício para estimular o prolongamento)

5. Idem 4 para o agudo

** Nos próximos dois encontros manter esse roteiro:

1 encontro:

No 2: quanto mais alto, mais longo, quanto mais baixo mais curto

No 4 e 5: fazer com longo e curto

2 encontro:

No 2: quanto mais alto, mais forte, quanto mais baixo, mais curto

No 4 e 5: fazer com forte e fraco.

ANOTAÇÃO:

O ator constrói a primeira melodia no corpo, depois insere as dinâmicas, isso parece ser mais natural para o ouvido humano 


\section{COMPONDO CENA A PARTIR DO ESTADO MUSICAL}

- Novembro de 2010

1. Movimentando-se livremente para alongar o corpo

a. Emitir sonoridades alongando-as

b. Movimento conduz a sonoridade

c. Sonoridade conduz o movimento

2. Música externa, escolhida por mim (ANDES) conduz a movimentação do corpo e da voz no espaço

a. A música termina, mas o "estado" deve ser mantido com a continuidade de movimentos e sons

3. Introduzo a música "I feel a little spaced out" dos Mutantes, que passa a conduzir a movimentação corpórea e sonora.

b. Ao final da música, os atores devem manter o "estado", continuando movimentos e sons que surgiram

c. Atores passam a se relacionar, jogando entre si a partir dos "insights" despertados pelo jogo

4. Peço aos atores para ouvir a música uma vez mais e, em seguida, repetir o exercício 3B.

5. Conversa para a conscientização dos estados alcançados

6. Vamos para o texto, a partir do jogo 3B e da consciência dos estados conquistados. 
- Fevereiro de 2011

COMPONDO A CENA A PARTIR DAS DINÂMICAS DO SOM

1. Aquecimento Físico-Vocal

2. Caminhando e seguindo as instruções (C/ sonoridades e corpo):

a. $1 \rightarrow$ Forte

b. $2 \rightarrow$ Fraco

c. $3 \rightarrow$ Meio (forte/fraco)

d. 1 Palma $\rightarrow$ Agudo

e. 2 Palmas $\rightarrow$ Grave

f. 3 palmas $\rightarrow$ Maio (agudo e Grave)

g. A $\rightarrow$ Longo

h. B $\rightarrow$ Curto

i. $\quad \mathrm{C} \rightarrow$ Meio (longo)

3.

Deitados experimentam livremente as 9 sonoridades de partida

a. $\quad$ Realizar o percurso com as dinâmicas entre as 9

b. Inserem o texto

c. Passam o texto em grupo (na sequencia das falas)

4. Individualmente, trabalham as falas com as dinâmicas entre as 9 sonoridades de partida

a. Texto em grupo

FORTE/ GRAVE/ LONGO $\rightarrow$ FORTE/ GRAVE/ CURTO $\rightarrow$ FORTE/ AGUDO/ CURTO $\rightarrow$ FORTE/ AGUDO/ LONGO $\rightarrow$ FRACO/ GRAVE/ LONGO $\rightarrow$ FRACO/GRAVE/ CURTO $\rightarrow$ FRACO/ AGUDO/ CURTO $\rightarrow$ FRACO/ AGUDO/ LONGO 


\section{ALGUNS ENCONTROS SOBRE “RASTROS”}

- 08 de abril de 2011

\section{Ativação}

2. Trabalhando rastros a partir do corpo:

a. desenho no espaço com diversas partes do corpo: Cotovelos, orelhas, tornozelos, peitos, lombar, testa, nariz, joelho, topo da cabeça. Axila, livre, etc.

b. Visualize, sinta, perceba a cor e a textura dos desenhos

c. permita a emissão sonora durante o desenho

d. deixe que o som também crie rastros

e. inserir textos no desenho

3. Trabalhar cenas das publicidades 


\section{ENCONTRO SOBRE UMA PARTITURA MUSICAL DA CENA}

- 05 de maio de 2010

1. Aquecimento a partir dos pés (corpo e voz, acento e pausa no movimento)O

2. Após lembrar as 3 situações básicas da primeira cena (Sr. F com saco cheio do trabalho; Sr. F. louco para ir pra casa; Sr. F chega em casa e quer assistir o Sr. X). Cada um desenha a MUSICA da cena (anexos)

3. Cada um lê o que desenhou (conforme seu próprio entendimento)

4. Colocar a "partitura" no corpo (que inclui voz)

a. Faz primeiro e abandona

b. faz segunda e abandona

c. Faz terceira e abandona

d. Faz quarta como junção das 3 anteriores

e. Faz quinta que não pode ter nada das anteriores

Para os procedimentos a, b e c, repetir 3 vezes e, como lembrar, anota.

5. 1 ator (Luiz), não criou partituras: pega o que assimilou pela observação das outras partituras e reproduz condensando-as em uma única

6. Todos tem uma partitura que é a leitura da música que havia desenhado, mais outra criada sem a utilização dos movimentos e sons constantes da primeira (dá 2 leituras da mesma música para cada um). Agora fazem com falas.

7. Experimentamos diferentes situações da cena nas partituras.

(acabamos definindo personagens) 
TRABALHANDO A CENA (2) 4

- Maio de 2011

1. Despertar: Dança circular judaica

2. Mover articulações a partir da música (faixa 2 CD Israel)

3. Trabalhando com Vetores que vem do chão:

a. Iniciar com os pés, depois outros pontos de apoio;

b. perceber que ponto ter como origem do movimento vários locais distintos (nuca, barriga, lombar, etc.) em seguida, colocar a origem (ponto zero do vetor) no ponto de contato co o chão.

Obs.: Empurra, desequilíbrio, suspensão, deslocamento.

4. Para Re-aquecer a voz: Pensar em movimentos CORPO E VOZ CONECTADOS (a voz do corpo e o corpo da voz) colocando acentos e pausas.

Obs.: Ontem o Luiz, hoje a Nathaly ficaram com enjôo (ambos giraram muito)

5. Retomar as "partituras" de ontem (passar 2 ou 3 vezes)

6. "Afinação" da partitura (ontem recolhi as "músicas" que eles desenharam, hoje devolvo para que retomem o que criaram). Passam duas vezes olhando para a partitura uma sem olhar. Em seguida, redesenham a música com os ajustes necessários, já cientes de sua personagem na cena.

7. Passar criando falas (sem fixar, mas já apontando caminhos) 


\title{
ANEXO E \\ COLAGEM DA DISSERTAÇÃO DA PROFESSORA YEDDA CARVALHO CHAVES (2001) SOBRE OS PRÍNCÍPIOS DA BIOMECÂNICA
}

\author{
Os Princípios Básicos da Biomecânica
}

\section{Biomecânica}

1. A Biomecânica é fundada sobre o princípio de que se movendo a ponta do nariz, o corpo todo se move, O corpo todo é envolvido pelo movimento do menor órgão. Ocorre, antes de tudo, encontrar a estabilidade do corpo inteiro. À menor tensão, todo o corpo reage.

2. Na Biomecânica, cada movimento é composto por três momentos, a) intenção; b) equilíbrio; c) execução.

3. Os requisitos básicos da Biomecânica são a coordenação no espaço e em cena, a capacidade de encontrar o próprio centro dentro do grupo em movimento, a capacidade de adaptação, de cálculo e de precisão no olhar.

4. A Biomecânica não tolera nada de casual, tudo deve ser feito com consciência a partir do estoque de cálculos feitos em precedência. Todos que participam do trabalho devem estabelecer com precisão e ser conscientes da posição em que se encontra o próprio corpo, e também usar com desenvoltura cada parte do corpo para colocar em prática o seu propósito.

\section{Material}

5. O material da arte do ator é o corpo humano, o qual é constituído pelo tronco, as extremidades, a cabeça, a voz. No estudo do seu próprio material, o ator não deve partir da anatomia, mas da idoneidade do próprio corpo para tomá-lo material da interpretação.

6. O material da interpretação do ator é o próprio ator. Portanto, em uma mesma pessoa encontramos ao mesmo tempo material e construtor. Logo, para definir o ator podemos recorrer a uma fórmula, em que A2 é o material e Al é o construtor, o ator é a soma destes dois elementos em ação. 
7. Cada fornia de arte consiste na organização de um material "Para organizar o seu material, o ator deve ter uma bagagem vastíssima dos meios técnicos". A dificuldade e a especificidade da arte do ator está no fato de que o ator é ao mesmo tempo material e organizador do material. A arte do ator é matéria delicada. Em cada momento o ator é também compositor.

8. O estado físico do material bem treinado é o marco do nosso sistema de recitação. Durante a sua execução, cada tarefa é planificada com precisão em relação ao espaço cênico; então, todos os movimentos do ator, até os reflexos, serão bem organizados.

9. Cada forma de arte é fundada sobre a auto-limitação. A arte é sempre e acima de tudo uma luta com o material.

10. É inadmissível qualquer desatenção em relação ao plano técnico. Deve-se construir a desenvoltura e a plena execução do trabalho. Quando o material é tecnicamente bem equipado, preparado através de um treinamento, e só depois de satisfeita essa condição, é que se pode dar carta branca ao que chamamos de excitabilidade dos reflexos. Caso contrário o trabalho se transformará em falimento.

11. Através das leituras, das viagens e assim por diante, construir o próprio material de reserva, do qual, no momento exato, poder-se-á extrair inconscientemente o necessário.

12. Além da bagagem técnica, 0 ator utiliza 0 material de 'observação' que acumula no curso da vida. As observações da vida não são transportadas de peso no nosso trabalho (na nossa interpretação) com a precisão fotográfica, o que é utilizado são as qualidades extraídas do material, e que cada ator irá lapidar conforme sua própria técnica.

\section{Corpo}

13. O trabalho e a tarefa do ator é tomar consciência de si mesmo no espaço. É necessário estudar a fundo o próprio corpo, a fim de saber a cada momento e com exatidão como este corpo é visto quando assumi cada uma das posições em cena.

14. É necessário estudar a um do à mecânica do próprio corpo tanto para conhecer com exatidão a inter-relação e o funcionamento de cada mínima parte. Cada movimento, seja ele de um dedo mínimo, deve repercutir imediatamente em todas as partes do corpo: o movimento de uma única parte imediatamente reorganiza as inter-relações intercorrentes entre as várias partes. Deve-se penetrar nas leis do equilíbrio 
e saber organizar o próprio corpo de tal modo que seja possível encontrar tempestivamente, à ocorrência, o centro de equilíbrio.

15. Mas o exame e o estudo do corpo devem absolutamente partir dos movimentos elementares e fundamentais. Aqueles mais refinados surgem em seguida. De fato não se inicia o desenho de uma árvore a partir das folhas. O principio do nosso desenho é o tronco. No nosso trabalho os movimentos elementares e fundamentais são aqueles do tronco, os movimentos refinados são aqueles das tenras folhas que brotam somente quando o tronco está pronto.

16. Não existe ator de corpo sem graça, pode existir um ator incapaz de conduzir o próprio corpo, desajeitado, e que não saiba usá-lo. (Mounet- Sully sabia usar tão bem o seu olho estrábico, que toda Paris enlouquecia ao ver a habilidade com que ele sabia fulminar com os seus olhos, no momento exato).

17. As capacidades expressivas dos membros inferiores e superiores somente podem ser totalmente desenvolvidas quando se encontra o exato centro de gravidade de todo o sistema físico.

18. No uso das mãos e dos dedos é necessária uma enorme tensão e uma extrema estabilidade do corpo na sua inteireza.

19. As mãos do ator devem sei treinadas para que, além de ter a função do equilíbrio, elas também possam ter um papel independente na interpretação, como um elemento expressivo. Exemplo; as mãos de Eleonora Duse, de Constantin Stanislavski.

20. As pernas também cumprem o papel de molas de suporte para o dorso do ator; deste modo, elas devem estar preparadas a qualquer momento para receber um estímulo.

21. O deslocamento biomecânico sobre a área cênica é uma semicorrida, uma semi-caminhada, sempre sobre as molas.

22. Para o ator, o estudo do corpo implica também o estudo do figurino, que para ele deve ser como uma parte do próprio corpo; a falta de domínio sobre o figurino reflete na sua interpretação, por exemplo, se um ator colocar o seu chapéu incorretamente, isto significa que ele é insensível (apático) em relação ao seu corpo.

23. As extremidades (os braços e as pernas) são os únicos meios para determinar o equilíbrio e permitir que seja encontrado o centro de gravidade do próprio corpo. 


\section{Olhos}

24. Os outros meios expressivos são os olhos e a boca.

25. Pode-se distinguir um bom ator de um ator ruim pelos olhos: você nunca vê o olho do mau ator. É necessário treinar os olhos, concentrando o olhar sobre determinados objetos; se os olhos tendem a desviar-se do objeto, então é a força de vontade que deve mantê-los no ponto desejado.

26. Entrando em cena, o ator deve manter os olhos na linha do horizonte. Se por algum motivo ele desvia o olhar da linha do horizonte, este fato é percebido como um ato, uma ação, uma mudança de situação, um matiz significativo (ainda que se tratasse de um aspecto puramente técnico, se você arregala os olhos, o seu olhar expressará medo, e, no entanto poderia não estar amedrontado, mesmo assim o gesto é percebido como um sinal de medo).

27. Quando se consegue mantê-los na linha do horizonte, todas as outras posições dos olhos podem ser consideradas rakursy.

28. E necessário aprender a descrever com os olhos aquilo que queremos, isto é, assumir uma específica expressão dos olhos $\mathrm{cm}$ cada uma das várias situações.

29. Na ordem de importância vem primeiro os olhos e depois a boca. Se a boca é fraca e os olhos são apagados, quer dizer que o ator não consegue controlá-los adequadamente. Por isso, não convém interpretar quando se está cansado.

30. A articulação dos lhos é mais complexa do que aquela dos lábios. Os lábios têm uma grande experiência (devido ao grande exercício do falar, conversar). E indispensável exercitar-se a fim de dispor de um complexo de movimentos bem experimentados.

31. Mesmo para derramar uma lágrima, é necessário recorrer ao artifício. Devemos nos conhecer muito bem, ao ponto de saber qual aparato colocar em moto para que uma lágrima seja derramada.

32. O segredo da mímica de uma máscara- em uma hábil combinação de rakiirsy, arte de dominar os rakursy do próprio corpo - é a habilidade acrobática do fantasista. A mímica está no corpo e não somente no rosto. 


\section{Equilíbrio}

33. Calma imperturbável e perfeito equilíbrio são condições imprescindíveis para um trabalho de boa qualidade.

34- Cada um deve ter um equilíbrio convincente, uma reserva de atitudes, de poses e diversos rakursy que lhe permitam manter esse equilíbrio. Cada um deve procurar sozinho o equilíbrio necessário para aquele dado momento.

35. Cada um deve compreender e saber sobre qual perna está apoiado, à direita, à esquerda, ambas. Deve-se perceber imediatamente a intenção de trocar a posição do corpo ou de uma parte dele.

36. Nos exercícios preparatórios, durante os ensaios, todas as emoções serão indicadas com leveza, limitando-se a indicar com precisão onde e quando deve acontecer a explosão. Uma emissão de voz mal preparada tecnicamente leva necessariamente à perda de equilíbrio. Então, necessita-se procurar novamente esse equilíbrio, ou seja, recomeçar o trabalho desde o início.

37. O ator deve ter um senso de equilíbrio tão desenvolvido que o seu corpo deve sentir fisicamente as imperfeições do figurino que se adaptou ao corpo (capacidade típica do dandy que, mesmo sem olhar-se no espelho, sabe em que condições se encontram as peças que está vestindo).

\section{Rakursy}

38. Variações visuais da forma de um objeto colocado em uma posição insólita para o espectador, principalmente no que diz respeito ao plano horizontal.

39. A habilidade que consiste na colocação e deslocação do próprio corpo no espaço cênico, isto é, o jogo do rákursy; é um dos momentos fundamentais de controle do próprio material. Por exemplo, o 'bi ba bo' é um boneco com máscara neutra, no entanto, parece que em certos momentos está rindo e em outros, chorando". E isso em relação à variação de rakursy, pelo que deduzimos que o segredo não está na mímica, mas no movimento do corpo, graças aos adequados movimentos físicos uma máscara pode exprimir tudo. 


\section{Gesto - movimento - palavra}

40. Os atores não devem 'decorar' as falas [delegá-las à memória, mas recordá-las em base à memória loci, ou seja, a partir do lugar, da posição do próprio corpo em um espaço e em um tempo determinado].

41. Deve-se ter consciência de cada movimento até o fim. Para cada momento da tarefa indicada é necessário estabelecer um ponto de apoio. O início e o fim da execução de cada tarefa devem ser nitidamente acentuados. O ponto do início dever ser marcado. Cada exercício comporta uma série de pontos semelhantes.

42. A emissão vocal, indicador do grau de reatividade, deve sempre ter um suporte técnico. Essa não pode acontecer sem que tudo esteja em tensão, quando o material técnico estiver todo organizado.

43. Nos diversos segmentos do trabalho é necessário um estado de concentração para rever a passagem sucessiva e a modificação do movimento. Por isso os pontos de partida e de chegada.

44. Sintonização, atenção, tenacidade são os elementos do nosso sistema. Em primeiro lugar está a atenção concentrada no plano físico. A condição sem freios do corpo privado de tensão \{duncanismo) é inadmissível. Nós organizamos tudo, cada passo, cada mínimo movimento é sob controle. O olho trabalha sempre.

45. O gesto nasce como o resultado do trabalho de todo o corpo, é uma resposta ao movimento do corpo, e logo [o gesto] deve ser predisposto/posicionado segundo as leis de equilíbrio daquele dado movimento.

\section{Espaco}

46. O espaço ara o laboratório do ator. Sala vazia, sem espelho, sem móveis, somente qualquer acessório de forma geométrica (não uma cadeira, mas um cubo); cubos, esferas, paralelepípedos, uma vara, uma escada; para tentar experimentar, com constância, novas potencialidades acrobáticas do corpo.

47. No palco a tarefa principal do ator consiste em ter a percepção de si mesmo, do próprio 'pedaço de corpo' no espaço cênico.

48. O grande comediante italiano Guglielmo [sic] pedia para os seus atores [sic] a habilidade em adaptar-se na área cênica. $O$ movimento do ator sobre uma plataforma quadrada não é o mesmo sobre uma redonda. Os movimentos também são diferentes, dependendo da parte do palco em que são realizados: anterior ou posterior. 
49. O sistema de interpretação biomecânica é baseado no seguinte princípio; uma correta reatividade está subordinada a uma correta disposição do corpo no espaço. Em cada momento, os movimentos devem ser predispostos e posicionados corretamente.

50. Em presença de um grande número de personagens a orientação no espaço é de enorme importância. A tarefa de cada um é encontrar o seu percurso particular dentro do movimento complexo da massa.

51. Durante um exercício de grupo, cada um deve conhecer o seu lugar, encontrando-o em relação a todos os companheiros e ao espaço, dentro dos limites no qual trabalha. A precisão da orientação, o rigor do cálculo, a rapidez no olhar, tudo isso deve ser levado ao extremo (esta mesma faculdade de adaptação, de precisão no olhar, pertencem, mesmo que inconscientemente, aos habitantes das grandes cidades).

\section{$\underline{\text { Tempo }}$}

52. Desenvolver o sentido do tempo do mesmo modo que o sentido do espaço. Perceber a duração de uma pausa pelo ouvido, automaticamente, sem calculá-la.

53. Para o ator é tão importante escutar-se em cena quanto ver-se em cena. Lendo as biografias de muitos grandes atores aprendemos que eles escutavam a si mesmos por longos períodos sem pronunciar uma só palavra.

54. O ator deve ser extremamente sensível ao rítmico, deve ouvi-lo não somente com os ouvidos, mas com cada fibra do próprio corpo; ele deve saber, além de ouvir, dominar cada parte do seu corpo, para isso devem ser conciliadas rítmica e ginástica.

55. A pausa atrai muito, pois dá espaço para a interpretação. sentido de medida do ator e o seu tato sugerem sempre se uma coisa é supérflua, se uma outra pode ser feita diversamente. Se um ator não tem uma reatividade veloz pode perder muito tempo pensando, concentrando-se. Enquanto passa e uma situação à outra, preparando-se, sincronizando-se, 0 ator alonga os tempos de interpretação e a pausa toma-se realmente insuportável.

56. Para evitar que 0 ator se deixe levar pela anarquia, da dita "interpretação interior", devemos nos impor um autocontrole em cena, como acontece nas partituras musicais, em que cada compasso é dividido por um travessão [traço perpendicular na pauta]. Para cada compasso correspondem notas que podem ser cantadas, tocadas ou pausas de silêncio. 
57. Devemos estudar as leis da música. No momento em que pronunciamos uma frase somos compositores de uma melodia.

58. Ocorre precisar se o tom é maior ou menor [em música, altura das notas] em função do conteúdo.

59. Quando um exercício divide em pequenos elementos, deve- se atuar com o staccato; o legato aparece quando o exercício é executado como um fluxo ininterrupto.

60. Todos os atores que trabalham devem estar conscientes do momento em que podem passar de uma posição à outra. Depois de cada elemento, presente na tarefa indicada, é obrigatório uma cesura.

\section{Economia}

62. No trabalho é necessária uma extrema economia, um taylorismo ao máximo nível. Todas as tarefas devem ser executadas com o menor número de técnicas possíveis, através dos meios mais racionais.

63. Não se deve executar os movimentos livremente. É necessário observar uma grande economia de movimentos. (É disso que se julga a adequação do diretor e do ator.).

64. O melhor modo de verificar com um olhar a ordem recebida de andar de um ponto para outro é o de empregar o número de passos calculados em precedência para que exista a economia.

\section{$\underline{\text { Reflexos }}$}

65. A excitabilidade de reflexos é uma capacidade importante do ator. Ela é a reprodução das tarefas dadas pelo autor e pelo diretor em sentimentos, movimentos e palavras. A interpretação compreende a coordenação dos vários aspectos da excitabilidade dos reflexos. Os aspectos da excitabilidade dos reflexos constituem os elementos da interpretação do ator. Cada elemento da interpretação é formado por três momentos indispensáveis: 1. Intenção, 2. Realização, 3. Reação. A Intenção é a percepção intelectual de uma tarefa recebida externamente (autor, diretor, iniciativa pessoal do ator). A Realização é o ciclo dos reflexos de volição miméticos e vocais (o adjetivo mimético indica todos aqueles movimentos que surgem na periferia do corpo do ator, e também do ator no espaço). A 
Reação é a diminuição da vontade que foi satisfeita pela realização dos reflexos miméticos e vocais e coincide com a preparação de uma nova intenção.

$O$ ator deve ter a capacidade de solicitar os reflexos, e para isso deve reduzir ao mínimo o processo consciente de realização da tarefa (o tempo de reação normal).

66. A excitabilidade de reflexos nasce durante o trabalho como resultado do uso correto de um material bem treinado. É o oposto do temperamento, [por exemplo], 'eu começo a sentir certas emoções e depois o resto virá'.

\section{Pré-jogo ou Pré-interpretacão}

67. O trabalho do ator consiste em alternar a pré-interpretação com a interpretação.

68. A pré-interpretação prepara o espectador para compreender a situação cênica, não exigindo nenhum esforço por parte dele para receber todos os detalhes provenientes da cena.

\section{$\underline{\text { Técnicas }}$}

69. Para um ator o controle do corpo está sempre em primeiro lugar. Nós temos na cabeça não uma personagem, mas uma reserva de materiais técnicos. $O$ ator é um homem que organiza continuamente 0 seu material. Deve conhecer perfeitamente a gama das próprias possibilidades e todos os meios dos quais dispõe para executar um dado propósito. A profissão e um ator é diretamente proporcional ao número das combinações tomadas possíveis pela sua bagagem de meios técnicos.

70. A ginástica não serve para exercitar-se, o tipo ideal de esporte para o ator seria velejar numa barca a vela (saber conservar o próprio equilíbrio sobre uma pequena superfície confere ao ator aquele "sentido de centro» que possuíam os grandes atores como Eleonora Duse ou Coquelin, e que norteou o sistema de DalcrozeDelsarte ). O esqui, o tênis, o salto, o lançamento de disco são igualmente bons. O balé é absolutamente nocivo: não tem expressividade dramática e os passos, bem determinados, suprimem os traços individuais da criação. $O$ ator deve criar novas técnicas.

71. A ginástica (orientada não para 0 desenvolvimento unilateral da força muscular, mas para o desenvolvimento da elasticidade e da habilidade), as acrobacias, a dança, a dança rítmica, o boxe, a esgrima são matérias úteis, mas podem beneficiar 
somente se introduzidas como matérias acessórias no curso da biomecânica, matéria fundamental e indispensável para cada ator.

72. Hanako [atriz-dançarina] demonstrou os exercícios japoneses: representar um gato nos mínimos detalhes. Elaboração técnica (medo, estupor, pressa, convulsões...) da história de um criado que perdeu um dos doze ratos que trazia. E tudo era realizado de maneira puramente técnica.

73. O gesto é o resultado do trabalho do corpo todo. Cada gesto é sempre o resultado daquilo que $o$ ator carrega na sua bagagem técnica.

74. Na arte do ator distinguimos vários setores: acrobacia, música, dança, arte de vestir os figurinos e arte de relacionar-se com objetos de cena.

75. A técnica não filtrada pela vida conduz o ator a um abstrato acrobatismo de circo.

76. O treinamento técnico do próprio material precede o trabalho de composição da personagem.

77. Pode-se recusar as regras somente depois de tê-las assimiladas bem. O maior inovador é aquele que mais do que todos respeita as regras. A técnica dever existir para depois ser recusada.

\section{Emploi do Ator}

78. Classificação da máxima importância: o ator deve elaborar uma ferrenha linha de base, não deve cair no ecletismo, mas, antes, escolher uma ou mais máscaras; o diretor deve sempre escolher bem a sua companhia, de outro modo o desastre é inevitável.

79. Papel que $o$ ator assume em presença de dados requisitados, a fim de obter a realização plena e precisa de uma determinada faixa de personagens com funções cênicas definidas.

\section{Reserva}

80. Nunca se consuma totalmente (em relação à voz e à reatividade). O público deve ter sempre a impressão de que o ator ainda tenha abundantes reservas. "Mas olha aquele canalha, quanto ele ainda pode render". O mesmo em relação aos gestos. Devemos intrigar o público com as nossas possibilidades, de modo que ele se mantenha 
sempre em alerta, para ver se não o burlaremos; é o mesmo que ocorre quando voltamos pela centésima vez ao circo para ver o espetáculo de feras a fim de ver se desta vez elas atacarão o domador.

81. Piano e forte são sempre relativos. O público deve sempre ter a impressão e uma reserva inutilizada. Em nenhum momento 0 ator deve gastar toda a provisão de materiais que possui. Mesmo o gesto mais amplo deve deixar a possibilidade de algo ainda mais amplo.

82. Lei geral do teatro: aquele que permite desafogar 0 seu temperamento no início do trabalho, inevitavelmente se esgotará antes do fim e comprometerá toda a interpretação.

\section{Exercícios}

83. Fixar um tema para o exercício é uma necessidade da qual é difícil fugir. Torna-se muito fácil para o corpo interpretar com um tema definido. Todavia, é necessário nunca se distrair e evitar interpretar o tema. Deve-se prestar uma atenção rigorosa em cada elemento do exercício (e ter plena consciência). Somente assim obter-se-á a precisão do trabalho.

84. É importante que cada exercício seja executado com zelo, não somente no sentido do correto trabalho, mas também da beleza exterior (parad) [é o nome que se dá às entradas e saídas de cena], do uso da área cênica, do efeito etc.

85. Cada exercício é precedido por uma apresentação, á qual se segue um momento de concentração antes do trabalho. Somente com um material bem agrupado pode-se começar a execução de uma tarefa.

86. Assim como a música é sempre uma sucessão precisa de medidas que não rompem nunca o conjunto musical, do mesmo modo os nossos exercícios são sequencias de deslocamento de uma precisão matemática que devem ser nitidamente distintas, elemento que não prejudica minimamente a limpeza do desenho do conjunto.

87. O espectador deve sentir a inquietude. Observando o exercício, ele segue a ação de alavancas que agem e respondem entre si.

88. O ideal é que 0 ator interprete com 0 figurino a partir do primeiro ensaio. Controlar-se no espelho. Geralmente espelho não serve para o ator. Ele deve perceber interiormente tudo o que ele é exteriormente. 


\section{Companheiros}

89. Durante um exercício executado com um companheiro, enquanto ele atua a verificação, cada um deve, através de um sinal de otkaz ou de um outro modo imperceptível ao espectador, informar ao companheiro que e pronto para executar a tarefa sucessiva.

90. Nos exercícios coletivos os participantes devem renunciar definitivamente ao desejo constante do ator: tomar-se solista.

91. Cada participante deve ter uma linha diretriz do movimento geral em um exercício coletivo.

\section{Objetos}

92. Um objeto na mão é uma extensão da mesma.

\section{Maquiagem}

93. Às vezes é suficiente que seja somente indicada, colocando somente as linhas simples e precisas da máscara. Neste caso, não cabe marcar rugas e os traços característicos do rosto de maneira naturalista.

\section{Composicão Paradoxal}

94. Por exemplo, quando uma personagem trágica pelas suas funções é usada pelo diretor em funções cômicas.

95. Com o objetivo de melhor capturar a atenção do público para obter o efeito desejado, ás vezes os dramaturgos recorrem ao deslocamento o completa transformação da composição dramática; assim uma situação tradicionalmente cômica desenvolve-se em um plano trágico ou vice-versa.

\section{Público}

96. A peculiaridade da arte do ator - e que o diferencia do escritor, do diretor e de outros artistas - reside no fato que o processo criativo acontece diante dos espectadores. Consequentemente $\mathrm{o}$ ator se encontra em uma espécie de interdependência 
com o espectador, e este último assume o papel de caixa de ressonância viva e pronta para reagir a todas as manifestações de habilidade do ator. $O$ ator, por sua vez, atento em seguir a caixa de ressonância (o público), através do seu fino ouvido, reage instantaneamente, por meio de improvisação, a todas as exigências que emergem. Graças a uma série de sinais (barulhos, movimentos, golpe de tosse, risadas), o ator deve individualizar com segurança o comportamento do espectador diante do espetáculo.

\section{Teatro e vida}

97. O desprendimento da vida leva o movimento dramático a um acrobatismo de circo. Só o salto não é suficiente, deve brilhar um elemento já conhecido, em outras palavras, a vida. 